


\section{Atlantic Continental Shelf and Slope of the United States- Sediment Texture of the Northeastern Part}

By JOHN SCHLEE

GEOLOGICAL SURVEY PROFESSIONAL PAPER $529-\mathrm{L}$

Description of the bottom sediment on the continental margin off New England with emphasis on the sources of the sediment and the processes that have dispersed it

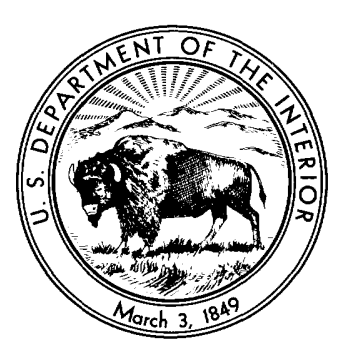

UNITED STATES GOVERNMENT PRINTING OFFICE, WASHINGTON : 1973 


\section{UNITED STATES DEPARTMENT OF THE INTERIOR}

ROGERS C. B. MORTON, Secretary

GEOLOGICAL SURVEY

V. E. McKelvey, Director

Library of Congress catalog-card No. 72-600342

For sale by the Superintendent of Documents, U.S. Government Printing Office Washington, D.C. 20402

Stock Number 2401-00280 


\section{CONTENTS}

Abstract
Introduction
Acknowledgments
Topography Continental shelf
Continental slope
Continental rise
Sediment
Sample collection and analysis
Description
Statistical measures
Median size
Polymodal distribution
Sorting
Skewness
Kurtosis
Curve shape
Normal types

\begin{tabular}{r|r} 
Page & \\
2 \\
2 \\
3 \\
3 \\
6 \\
6 \\
8 \\
8 \\
9 \\
13 \\
13 \\
14 \\
18 \\
19 \\
22 \\
24 \\
27
\end{tabular}

\section{ILLUSTRATIONS}

[Plates are in pocket]

Plate 1. Map showing sediment type on the continental margin off the Northeastern United States.

2. Maps showing areal distribution of gravel, sand, silt, clay, and median grain size of sediment on the continental margin off the Northeastern United States.

3. Map showing principal modal grain size on the continental margin off the Northeastern United States.

4. Maps showing some textural parameters of grain size for sediment on the continental margin off the Northeastern United States.

5. Bathymetric map of the continental shelf off New England showing the types of sea floor based on echograms.

6. Map showing echo-sounding survey in the western Gulf of Maine and bottom and subbottom profiles along sounding tracks.

Figures 1-4. Bathymetric maps:

1. Continental margin off the Northeastern United States

Page

2. Continental margin off New York and New Jersey

3. Lower continental slope at site of Thresher search area

4. Northeastern Atlantic continental margin showing location of samples

5. Ternary textural diagrams of sediment from the continental margin off Northeastern United States

6. Ternary textural diagrams of sediment from the Gulf of California, Gulf of Paria, and Gulf of Mexico

7. Map showing number of modes in grain-size distribution in sediment samples from the continental margin off Northeastern United States

8. Histogram showing modal grain sizes

9. Maps showing patterns of potential sediment transport on the continental margin off Northeastern United States

10. Scatter plot of median grain size versus standard deviation 
Figures 11-13. Scatter plots:

11. Skewness versus median grain size

12. Skewness versus standard deviation for estuarine sediment, basin sediment from the Gulf of Maine, and beach sands -

13. Skewness versus standard deviation for nearshore sand and gravel 14-16. Scatter plots of skewness versus kurtosis :

14. Sediment samples from the continental margin off Northeastern United States ---.--

15. Samples from beaches, estuaries, and basins in the Gulf of Maine

16. Nearshore sands

17.

Graphs showing averaged cumulative grain-size distribution

18. Graph showing representative cumulative grain-size curves of well sorted sand

19. Graph showing representative cumulative grain-size curves of moderately sorted silt

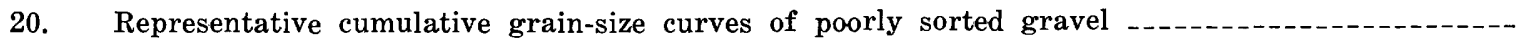

21. Representative grain-size curves of skewed type

22. Representative cumulative grain-size curves of polymodal type

23. Examples of cumulative grain-size curves different from those shown in figures 18, 19, 20, 21, or 22

24.

Passega C-M diagrams for different types of deposits

25.

C-M diagram of the fields in the five curve-shape types

Superposition of figures 24 and 25

Echo-sounding traces showing six distinctive types of sea floor

Schematic cross section showing sediment facies in the Gulf of Maine and adjacent areas

Index map of seismic profile tracks

Continuous seismic profiles of the New Jersey-Long Island area

Continuous seismic profiles on the continental shelf and upper slope south of Rhode Island and Martha's Vineyard

Map showing thickness of silty sediment in vicinity of Block Island and the shelf south of Martha's Vineyard

Thickness and lithology of cores in vicinity of Block Island and the shelf south of Martha's Vineyard

34.

Continuous seismic profiles across Georges Bank, Great South Channel, and Georges Basin -.--

35.

Continuous seismic profiles of the continental slope and upper rise

36.

Texture and length of five cores collected on the upper continental slope south of Martha's Vineyard

37. Map showing current-velocity measurements on the continental margin 


\title{
ATLANTIC CONTINENTAL SHELF AND SLOPE OF THE UNITED STATES- SEDIMENT TEXTURE OF THE NORTHEASTERN PART ${ }^{1}$
}

\author{
By JohN SchleE
}

\begin{abstract}
The Atlantic continental margin of northeastern United States is covered by fine to medium quartzose sand out to the shelf edge and by silt and clay on the continental slope and rise. On the glaciated part of the continental shelf (Gulf of Maine), sediment is mainly till-like mixtures of sand, gravel, silt, and clay; in basins of the gulf, pelagic silty clay veneers older glacial deposits. Adjacent to the rocky shelf around Nova Scotia, coarse gravel is prevalent.

Past and present depositional agents have affected both the topography and type of sediment on the continental margin. Coarse cobbles and boulders occur mainly in the Gulf of Maine where glaciers deposited them. They are particularly well exposed as a lag on banks and ledges mainly as the result of winnowing of these elevated areas by bottom currents. Silty clay, several meters thick, from the glacial debris has settled in depressions occupied by tongues of the ice sheet and covers the glacial deposits. The southern limit of glaciation is marked by a fringe of gravelly sand (former outwash deposits) and sandy gravel that stretches from moraines on Martha's Vineyard and Nantucket, southeastward across Nantucket Shoals and Great South Channel, and along the northern part of Georges Bank, where boreholes penetrated as much as 120 feet of sand with stringers of gravel. The shelf south of the glacial limit is mainly a sand-covered plain transected by wide channels and carved by a dendritic drainage pattern southeast of New York and New Jersey; relict terraces inherited from lower stands of sea level are also prevalent in this area, particularly on the outer shelf. Sandy debris has been redistributed so widely over Georges Bank and the inner shelf elsewhere, that the channelways for glacial melt water are now buried, though they can be detected on continuous seismic profiles.

Fine-grained sediment on the shelf is confined to inshore areas such as estuaries, bays, and sounds and to one large area on the shelf south of Rhode Island and Cape Cod. This last area of silty sand and sandy silt veneers older deposits of sand and probably originated through ponding of fine detritus on a shallow part of the shelf during the Holocene rise of sea level.

The bathymetric transition to the deep sea is marked by a change to finer grained sediment on the continental slope. The sand fraction lessens and changes from dominantly quartz and feldspar to mainly planktonic Foraminifera tests. Patchy reversals in the trend are due to rafting or slumping of debris down the slope and to flushing of coarse detritus down submarine canyons.
\end{abstract}

Statistical and nonstatistical measures of grain size are affected by the mixing of basic populations of gravel, sand, and silt plus clay, by one of several processes. Modes show a complex pattern on the continental shelf, in part related to transport of sand along shore during lowered stands of sea level in the Holocene. Gradients toward finer modal grain size are best developed at the shelf edge down the continental slope, where sea level stabilized during glacial stages of the Pleistocene; the gradient relates poorly to existing patterns of sediment transport on the shelf and hence supports the inference that much shelf sediment is relict. Median grain size is a good describer of sediment where it is fairly well sorted and unimodal. Much sediment, however, is both poorly sorted and polymodal, particularly in the Gulf of Maine. Standard deviation relates well with past and present processes that have dispersed the sediment. Till-like deposits in the gulf and sandy gravel outwash deposits around the gulf show poor sorting due to: (1) an inability of the ice to sort the debris, and (2) the transport of sand and gravel by different processes. Transport mainly by a single process and of a single basic population leads toward unimodal normally distributed sediment with moderate or excellent sorting. An example would be the current-swept shoals composed of coarse to fine quartzose sand southeast of Nantucket.

Skewness and kurtosis show a very patchy areal distribution of values; scatter plots with each other and with standard deviation and median lend support to the idea that skewness and kurtosis are a partial measure of the degree of mixing between basic populations. Clustering of points in these plots is influenced by source, in that the points are more tightly clustered where sedimentary formations under the shelf and Coastal Plain are the probable source of detritus, in comparison with those values from reworked glacial deposits in the Gulf of Maine.

Analysis of the shape of grain-size curves shows that three types approximate log-normal distribution and two other types are not normal. A comparison of the normal types with those from other settings and with Passega C-M diagrams shows that ice, tractive bottom currents, and pelagic suspensions are the main deposition agents. Most of the sands plot as log-normal distributions with a steep slope; they show obvious similarity to current-winnowed sediment in sand waves and beaches. Deep-water or sheltered-

\footnotetext{
1 Contribution 2437 of the Woods Hole Oceanographic Institution, based on work done under a program conducted jointly by the U.S. Geological Survey and the Woods Hole Oceanographic Institution and financed by the U.S. Geological Survey.
} 
water deposits of silt and clay likewise tend to be log normally distributed, though with a moderate sorting. These deposits are most similar in curve shape to gravity-settled clays from abyssal plains and sheltered bays. Poorly sorted mixtures of sand, gravel, silt, and clay from the Gulf of Maine tend to be log normal in their distribution and to show a similarity to tills deposited on land. Polymodal mixtures of sand and gravel show a nonnormal steplike curve and probably reflect transport by saltation and suspension for the sand, and surface creep or ice for the gravel. The size distribution curve of most of the silty sand on the upper continental slope and on the flanks of basins in the Gulf of Maine is skewed toward the coarse fraction to give an asymmetrical distribution of moderately sorted silt and clay in with fairly well sorted sand. This type sediment generally covers a transitional area between well-sorted log-normally distributed sand of the shelf and moderately sorted log-normally distributed silty clays of deeper water areas; hence, it may be the result of two processes of sedimentation-deposition of sand by currents and pelagic deposition of silt and clay. Thorough biogenic reworking has mixed the two components.

\section{INTRODUCTION}

The areal distribution of sediment on the continental margin off the Northeastern United States reflects a complex Quaternary history. Repeated changes in sea level and glaciation of the northern part of the margin have left a strong imprint on the type of bottom sediment and on the bathymetry. This report describes the texture of the surficial sediment, its relation to topography, its sources, and the types of processes which have acted to disperse and deposit it.

Pourtales (1872) published the first sediment map of the Atlantic continental margin. In it he showed three zones of sediment roughly parallel to the coastline; most of the shelf is shown as sand and gravel except for a muddy zone south of New York and Connecticut. The deep sea floor beneath the Gulf Stream is shown as foraminiferal ooze, and a mixed zone of sand and ooze lies seaward of the shelf break, on the upper continental slope. Regional maps of the sea-floor sediment were published by Burbank (1929) for the Gulf of Maine, Shepard (1932) for the Atlantic Continental Shelf, Shepard, Trefethen, and Cohee (1934) for Georges Bank, Shepard and Cohee (1936) for the continental shelf off the Middle Atlantic States, and the German Navy (Oberkommando der Kriegsmarine, 1943) for the continental shelf adjacent to the Eastern United States. Stetson (1938) made seven profiles in the study area, normal to the coastline of New York and New England; many of these showed fluctuating values of median grain size and only a partial development of a profile of equilibirium on the landward edge of the continental shelf. Shepard and his coworkers emphasized the relict nature of much sediment on the continental shelf and the Gulf of Maine, the lack of a size gradation away from the coast, and the absence of fine sediment on the shelf-because currents have swept it into deeper water. Wigley (1961) also emphasized this lack of a gradation to finer grain size in deeper water away from Georges Bank. On the continental shelf south of New England, Garrison and McMaster (1966) pointed out the relict nature of the sediment (except for sandy areas near Nantucket Shoals). Hathaway, Schlee, Trumbull, and Hülsemann (1965) and Emery (1968) also emphasized the relict nature of much sediment on the continental margin in terms of the processes of Pleistocene age that brought it there; postglacial reworking of bottom sediment in limited areas such as the shoals of Georges Bank have redistributed fine-grained sediment onto the basins of the Gulf of Maine (fig. 1).

From these studies and many others of smaller areas (McMaster, 1962; Schlee, 1964; King, 1965, 1967; Ostericher, 1965; Uchupi, 1966a, b, c), the following conclusions emerge.

1. Large fluctuation of sea level have resulted in a complex association of Pleistocene fluvial, estuarine, and glacial deposits on the continental shelf.

2. Post-Pleistocene events modified these patterns of Pleistocene sedimentation, mainly in the shallow and nearshore areas.

3. Sources for bottom sediment are (a) Tertiary and Cretaceous strata underlying the shelf and adjacent Atlantic Coastal Plain, (b) glaciofluvial deposits, and (c) present-day river sediment (Ross, 1967).

\section{ACKNOWLEDGMENTS}

Many of my colleagues on the project aided through discussion of the various geologic aspects. Among them are K. O. Emery, Elazar Uchupi, and D. A. Ross of the Woods Hole Oceanographic Institution, R. H. Meade, J. C. Hathaway, and R. N. Oldale of the U.S. Geological Survey, R. W. Wigley and R. M. Pratt of the National Oceanic and Atmospheric Administration. Many of the size analyses were made by D. J. Casey, J. R. Frothingham, Jr., C. R. Hayes, and Nancy Sideras. Jacqueline Webster and M. A. Rosenfeld of the Woods Hole Oceanographic Institution programed the data for statistical analysis. The report was reviewed by $R$. $H$. Meade, Elazar Uchupi, and A. T. Ovenshine. 


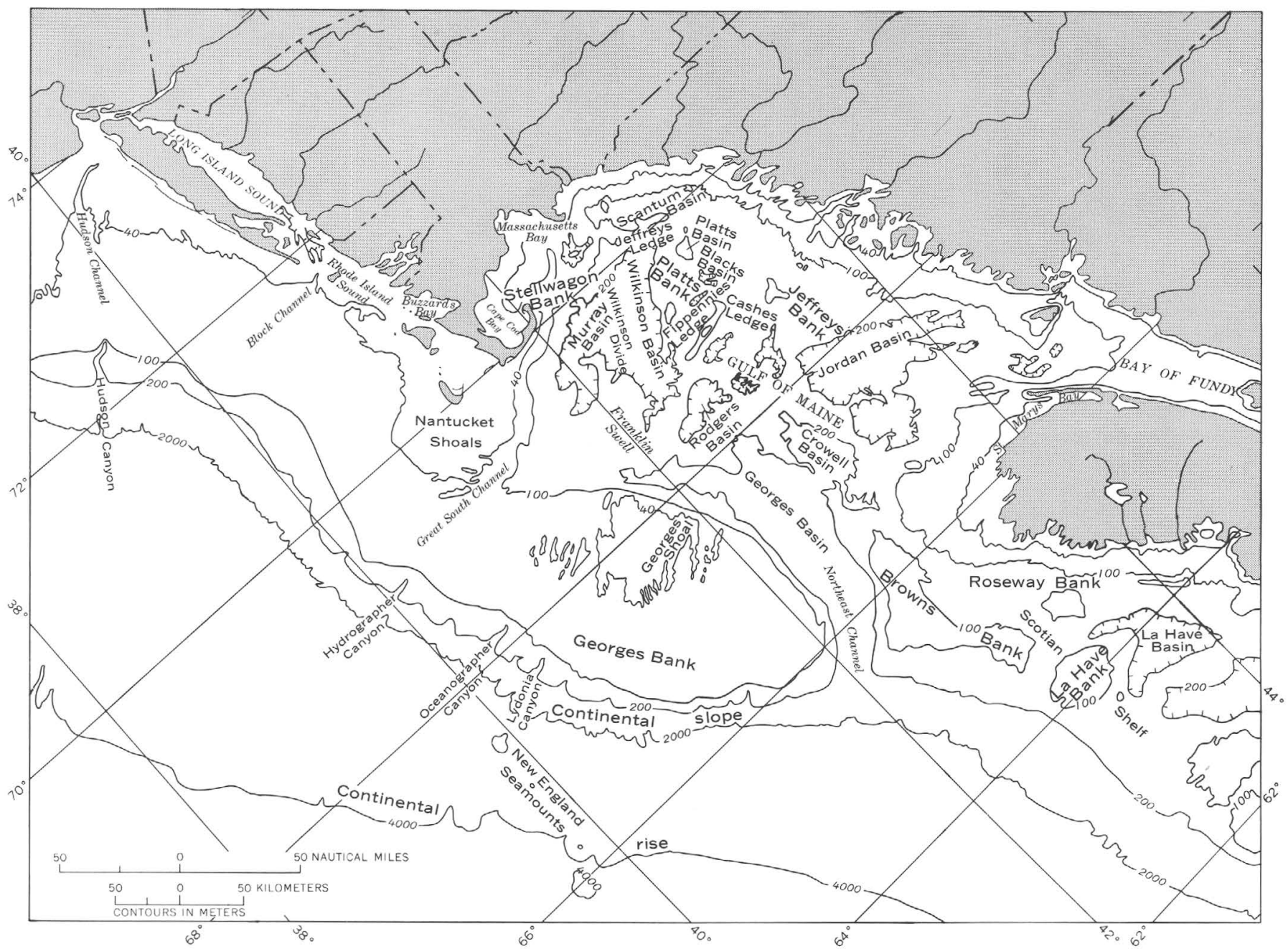

FIgURE 1.-Bathymetric map of the continental margin off the Northeastern United States. Adapted from Uchupi, 1965a.

\section{TOPOGRAPHY}

On the continental margin the topography and type of sediment are varied and tend to be related. As a prelude to discussion of the areal distribution of sediment, the physiography of the continental margin is described, particularly in terms of past and present forces thought to have shaped it. Bathymetry of the region has been compiled from U.S. Coast and Geodetic Survey smooth sheets by Veatch and Smith (1939), Uchupi (1965a), U.S. Coast and Geodetic Survey and U.S. Bureau of Commercial Fisheries (1967); scales range from 1:120,000 (U.S. Coast and Geodetic Survey and U.S. Bureau of Commercial Fisheries, 1967) to $1: 1,000,000$ (Uchupi 1965a, Veatch and Smith, 1939). Except for the map by Uchupi (1965a), most sheets cover the shelf and slope south of New England and east of the Middle Atlantic States. Smaller areas have been charted by Ostericher (1965) and McMaster (1960). These maps show a nearly flat nonglaciated continental shelf sloping seaward at a very low angle $\left(0^{\circ} 03^{\prime}\right)$, an intricately carved continental slope, and many basins, ledges, swales, and banks west of New England on the glaciated shelf.

\section{CONTINENTAL SHELF}

The continental shelf shows several forms of bathymetry (figs. 1 and 2) some of which relate to the Quaternary history of the margin. Significant features in figures 1 and 2 are: (1) the sand waves and dendritic drainage pattern over much of the nonglaciated shelf, (2) broad channels across the shelf, and (3) basin and shoal topography associated with the Gulf of Maine and Scotian Shelf.

The most extensive areas of sand waves and tidal shoals are southeast of Nantucket and also on the northern half of Georges Bank. Tidal ridges trend approximately northwest on Georges Bank and continue for several kilometers; superimposed on these broad ridges are smaller amplitude sand waves 


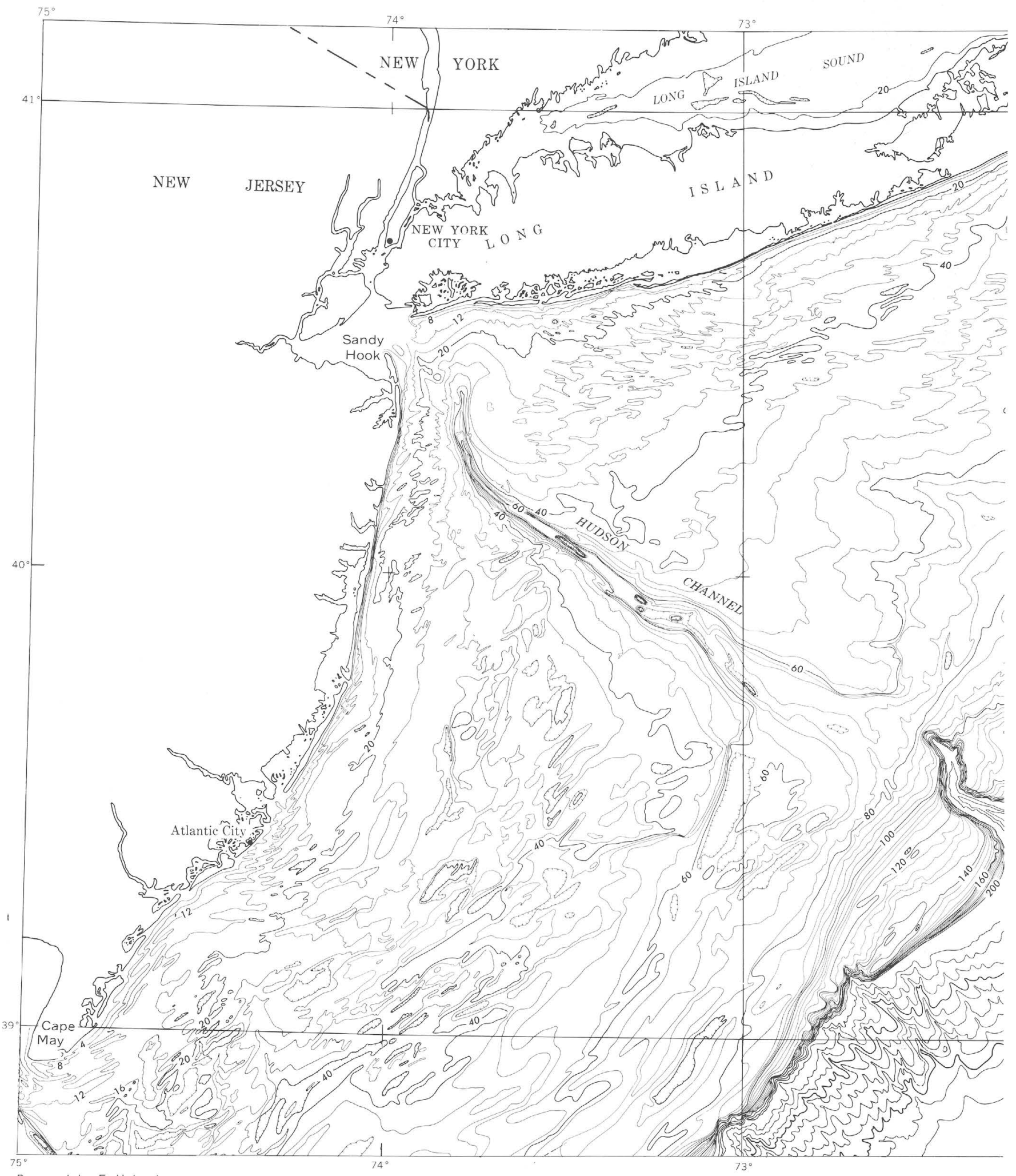

Prepared by E. Uchupi

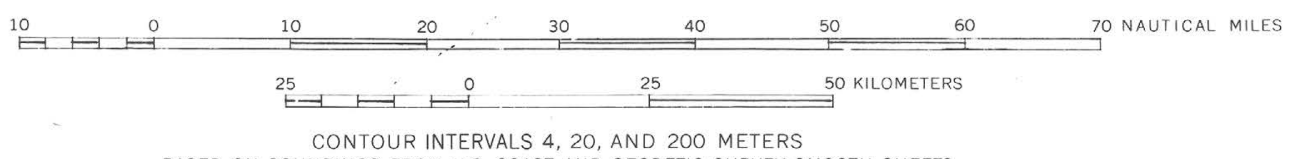

BASED ON SOUNDINGS FROM U.S. COAST AND GEODETIC SURVEY SMOOTH SHEETS 


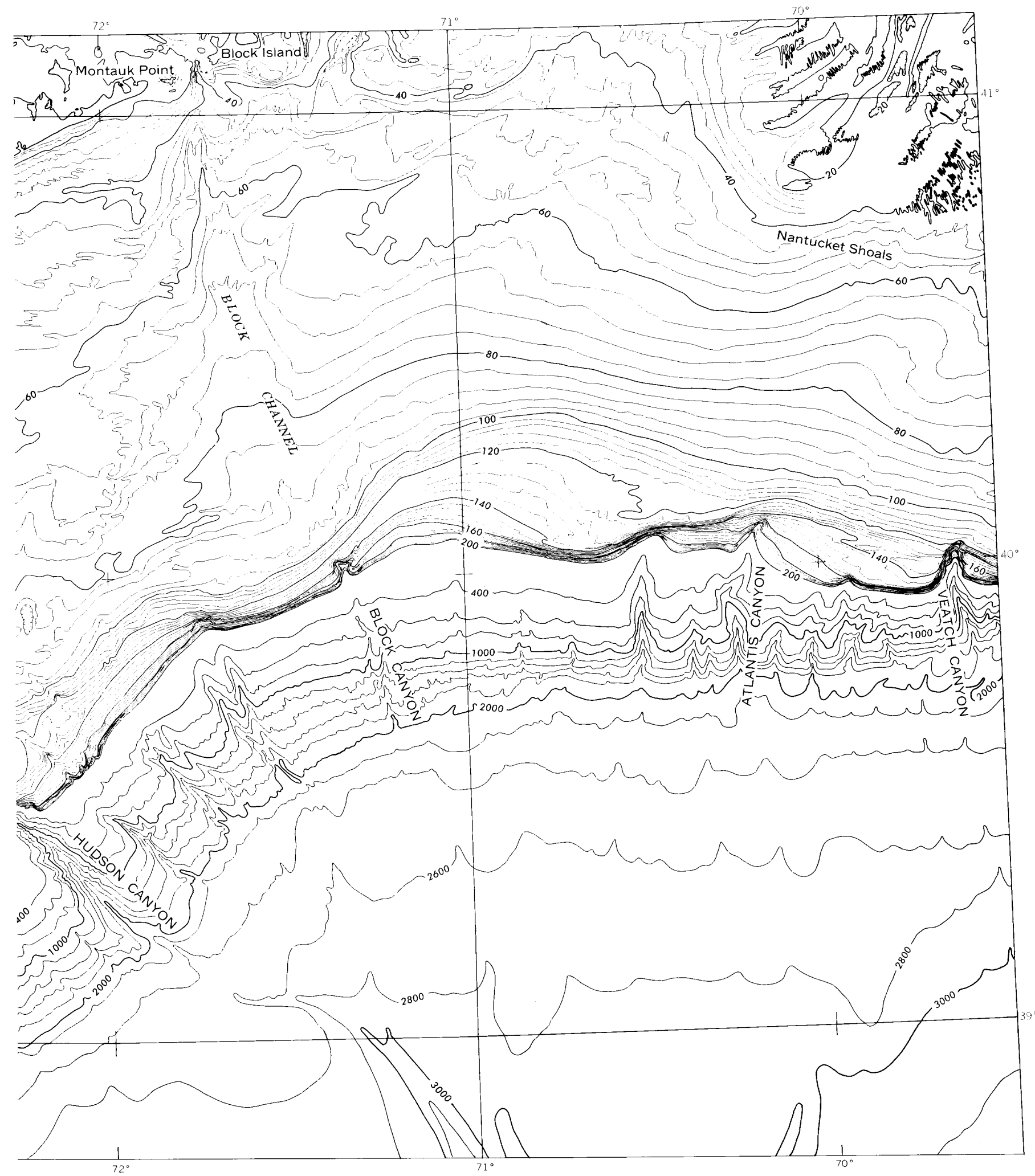

Figure 2.-Bathymetric map of the continental margin off New York and New Jersey. Contour interval 4 and $20 \mathrm{~m}$ to a depth of $200 \mathrm{~m}$, and $200 \mathrm{~m}$ interval beyond that depth. Adapted from Uchupi, 1970. 
whose axes are normal to the axial trends of the tidal ridges (Stewart and Jordan, 1964; Uchupi, 1968). East of New Jersey and south of Long Island, topographic contours form an intricate series of sand ridges and swales whose trend is at a low angle to the present coastline. Successive groups of these ridges and swales are intersected at a low angle by "scarps" (Veatch and Smith, 1939) straight or broad arcuate terracelike breaks in slope, which can be traced for several kilometers. Veatch and Smith portray these "scarps" as straight features, little indented by ravines. Stearns and Garrison (U.S. Coast and Geodetic Survey and U.S. Bureau of Commercial Fisheries, 1967) show these same features as more complex elongate breaks, dissected by broad swalelike valleys.

Broad shallow channels crossing the continental shelf are the Hudson Channel southeast of Long Island, Block Channel south of Rhode Island, and Great South Channel, southeast of Cape Cod. One deep channel (Northeast Channel) provides a deepwater entrance to the basins of the Gulf of Maine and is thought to be a river valley carved before the Pleistocene and subsequently modified by glacial erosion (Torphy and Zeigler, 1957; Uchupi, 1966a). The shallow channels are thought to be relict fluvial Pleistocene drainageways formed during lower stands of sea level in glacial stages. Some of the channels (Block, for example) are the main trunk of an intricate dendritic drainage system on the continental shelf (Garrison and McMaster, 1966) and terminate seaward in lobate bulges of the outer continental shelf thought to be deltas.

Much of the outer continental shelf is featureless south of New England, on Georges Bank, and on the Scotian Shelf. In topography and sediment it has been compared by Veatch and Smith (1939, p. 22) to the flat sand plains of the Sahara Desert. Imprinted on this surface are the faint impressions of landforms inherited from lower stands of sea level; these former strandlines show as terraces or slight increases in the slope of the shelf (Ewing and others, 1963; Uchupi, 1968). Some, such as Nichols and Franklin shorelines near the outer edge of the shelf, are more pronounced and can be traced for several kilometers north and south of Hudson Canyon.

The irregular topography of the Gulf of Maine and inner Scotian Shelf shows the effects of glacial erosion and deposition (Burbank, 1929; Shepard and others, 1934; Uchupi, 1965b; King, 1965). The gulf is characterized by irregular closed basins $64-$ $377 \mathrm{~m}$ deep (fig. 1), and 90-10,400 sq km (square kilometers) in area (Uchupi, 1965b). Basins on the
Scotian Shelf are similar in depth though fewer in number (King, 1965). Areas between the basins are hummocky and rolling and dotted with ledges, banks, and smaller closed depressions. The submarine topography is reminiscent of the irregular rolling topography of hillocks, lakes, swamps, and complex drainage so evident in glaciated parts of the United States like New England (Hartshorn, 1967) and the northern midwest (U.S. Geolological Survey topographic map, Stockbridge quadrangle, Michigan).

CONTINENTAL SLOPE

The continental slope off the Northeastern United States assumes two generalized forms (Uchupi, 1968). Adjacent to most of the Scotian Shelf the slope is relatively gentle (Heezen and others, 1959, pl. 24; Uchupi, 1968, fig. 32), averaging $4^{\circ}-5^{\circ}$. In that area it merges with the continental rise at depths of 1,000-1,200 m and tends to be smooth and indented by very few ravines or submarine canyons. Off Browns Bank and to the south, the continental slope is much more intricately channeled, steeper $\left(5^{\circ}-7^{\circ}\right)$, extensively cut by large submarine canyons, and the break at the base of the slope gradually deepens to $2,000 \mathrm{~m}$. To the north, the change in slopes, loss of canyons, and rise in the base of the slope-rise break has been attributed to increased deposition from glacial sources (Uchupi, 1968; Schlee and Pratt, 1970).

Larger scale maps by Veatch and Smith (1939) and the U.S. Coast and Geodetic Survey and U.S. Bureau of Commercial Fisheries (1967) show a general dendritic pattern on the continental slope. Veatch and Smith show an extremely intricately branching pattern in part based on what they surmise the slope should look like; analogies are drawn to gullied slopes in California. Stearns and Garrison (U.S. Coast and Geodetic Survey and U.S. Bureau of Commercial Fisheries, 1967) are more conservative and portray the slope more smoothly.

One detailed study (Emery and Ross, 1968) made of the lower continental slope $170 \mathrm{~km}$ (kilometers), south of Martha's Vineyard, showed the area to be a gentle surface incised by a few broad gullies over an area of $50 \mathrm{sq} \mathrm{km}$. A more detailed survey over a restricted part of this slope (area $12 \mathrm{sq} \mathrm{km}$ ) showed it to be gently inclined to the south, and to be crossed every $1 / 2-3 / 4 \mathrm{~km}$ by a ridge approximately $100 \mathrm{~m}$ wide, $2-10 \mathrm{~m}$ high, and trending downslope. The authors offer no explanation for the ridges, but they do note that such ridges could be the result of a downslope movement of sediment.

CONTINENTAL RISE

The rise is a very gently sloping (generally less than $1^{\circ}$ ) surface which deepens from approximately 
2,000 to $5,000 \mathrm{~m}$ (Uchupi, 1968). It has been further subdivided into an upper continental rise extending down to about $4,000 \mathrm{~m}$, and a lower rise of lesser slope, extending to the abyssal plain (Heezen and others, 1959). The change from upper to lower rise is also marked by a change in the sediment properties (Schneider and others, 1967).

Again, one detailed study is all that is available for the upper continental rise. Hurley (1964) pub- lished a survey for a small area of $160 \mathrm{sq} \mathrm{km}$ on the rise at the site of the Thresher sinking, it was based on sounding lines $230 \mathrm{~m}$ apart (fig. 3). It shows the channeled topography of the continental rise near Northeast Channel. On the small-scale map with a 100 -fathom contour interval, the upper rise appears less furrowed, but the detailed map shows some well-developed valleys with a relief of 55-70 $\mathrm{m}$ and a width of $2 \mathrm{~km}$. Other valleys are much $65^{\circ} 00^{\prime} \mathrm{w}$

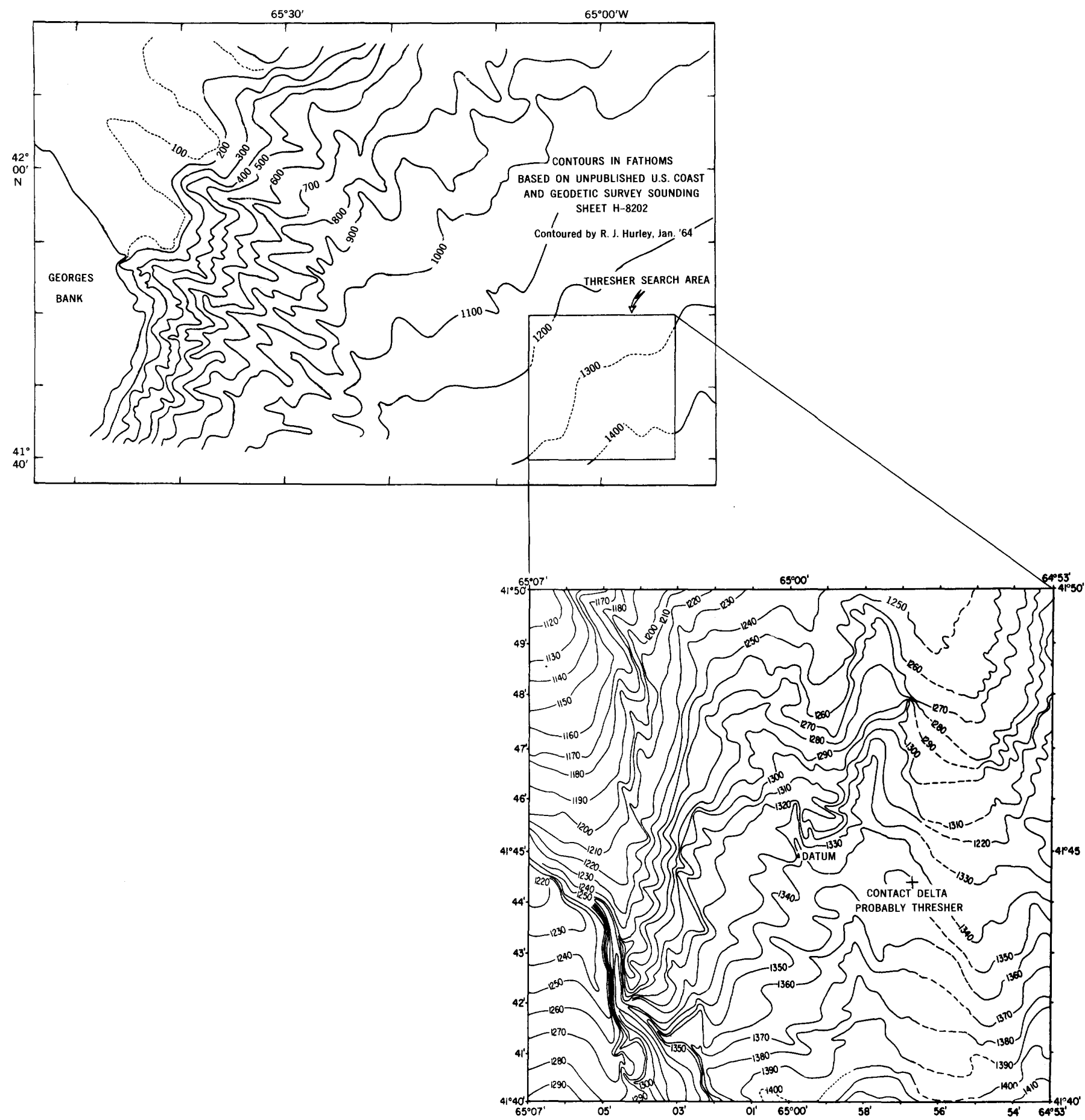

FIGURE 3.-Bathymetric map of the lower continental slope at the site of the Thresher search area (from Hurley, 1964). 
broader, have a lower relief, and appear to head in the survey area. From this map, we can see that valleys trend approximately down the gentle slope of the rise and that they could serve as channelways for downslope transport of sediment to the lower part of the rise. Some valleys are well developed as in the southwest corner, though others are poorly defined, and contours are irregularly spaced.

This brief description of the continental margin indicates how variable it is in physiography-a variation in part reflecting the many agents that have shaped it. On the continental shelf, sand waves and tidal ridges are on the shallowest part of the shelf. Relict terraces, cross-shelf channels, and dendritic drainage patterns attest to past fluvial erosion and lower stands of sea level. Sculpturing by glacial ice in the Gulf of Maine has resulted in several large basins, ledges, and hummocky irregular topography.

\section{SEDIMENT}

SAMPLE COLLECTION AND ANALYSIS

Approximately 1,000 samples were collected, or about one sample for each $325 \mathrm{sq} \mathrm{km}$ (fig. 4) over an area encompassing $347,000 \mathrm{sq} \mathrm{km}$. As shown in the figure, samples are fairly uniformly distributed over the shelf and slope and more widely spaced over the upper part of the continental rise. Sampling gear and contributions of samples have been described by Emery (1966). The method of collecting bottom sediment with a grab bucket (clam shell) results in a channel sample of the sea floor, the depth of which depends mainly on the penetration of the gear. For coarse-grained sediment, penetration is shallow; sediment is obtained only within a few centimeters of the surface of the sea floor. Silty clay is much more deeply sampled (as deep as half a meter) and therefore the grain size is a composite of this interval. Where obvious changes

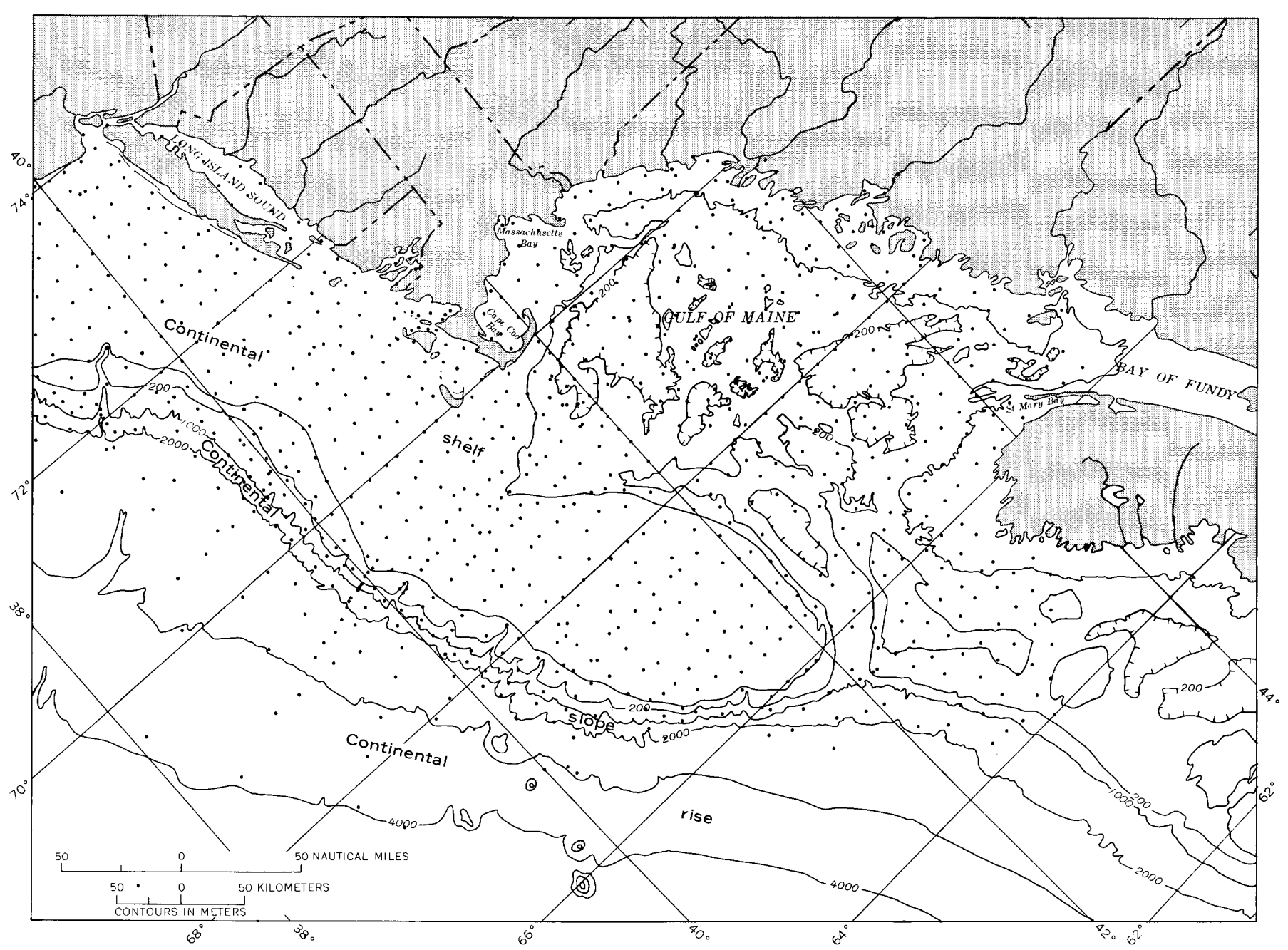

FigURE 4.-Map of northeastern Atlantic continental margin, showing location of samples. 
in sediment type occurred with depth, subsamples were collected (Hathaway, 1966), and only the uppermost layer in the sequence was analyzed.

The amount of bottom sediment obtained ranged from a fraction of a liter to as much as 140 liters. The adequacy of the sample obtained for grain-size analysis depends on the sediment type (Krumbein and Pettijohn, 1938, p. 32). For sand, silt, and clay, where only a few hundred grams of sediment are needed, the amount obtained by the grab bucket was adequate. Where gravel is prevalent, several tens of kilograms are needed for a sample. Of the 263 samples where the gravel fractions constituted 5 percent or more of the sample, approximately threefourths were inadequately sampled (Schlee and Pratt, 1970). Most of these samples were taken with buckets that collected only a few liters of sediment.

Samples were sized by different techniques, depending on the sediment type. Detritus greater than $2 \mathrm{~mm}$ (millimeters) was sieved (whole Wentworth size class interval), and material in the sand range was sized using a settling tube-a modified Woods Hole Rapid Sediment Analyzer (Schlee, 1966). Where finer grained sediment made up more than 10 percent of the total sample, the fraction less than $0.062 \mathrm{~mm}$ was pipetted (Krumbein and Pettijohn, 1938, p. 166-172). A 5 percent solution of sodium hexametaphosphate was used as a dispersing agent. Samples that flocculated despite use of a dispersing agent had most of the fluid removed on a filter candle apparatus; samples were then redispersed in a 1,000-ml (milliliter) glass cylinder. All samples to be pipetted were soaked at least 12 hours in distilled water prior to sieving, and all were subjected to disaggregation ultrasonically a minute prior to wet sieving at 0.062 of a $\mathrm{mm}$.

Grain-size distributions were analyzed statistically on a computer to pick the modes and to calculate the mean, median, sorting, skewness, and kurtosis. Details on computation of statistical parameters have been given by Schlee and Webster (1967) ; moment measures (Krumbein and Pettijohn, 1938) were used to characterize the size frequency curves.

Some extrapolation of data beyond the limits of the analysis was necessary. For those samples in which more than 5 percent of the fine-grained sediment was less than 1 micron, additional data points were estimated for the finer size grades (whole phi interval) by projecting the grain-size curve as plotted on probability paper, and following the same slope of the line, until more than 95 percent of the curve has been plotted. Approximately 10 percent of the samples were rejected for statistical analysis because an insufficient volume of sediment was obtained to sieve; these were gravelly sediment types where gravel made up 10 percent or more of the sample.

\section{DESCRIPTION}

A map of sediment type (pl. 1) shows that sediment is distributed in a patchy manner and is related to topographic features on the shelf. No smooth gradation exists from coarse-grained sediment near shore to finer grained sediment offshore, just as the topography shows no smooth gradually deepening continental margin (fig. 1). Broad features like the shelf south of New England are covered by sand and lesser amounts of gravel and silt. Under the deeper waters of the continental slope, sediment is clayey silt or silty clay; silty clay mantles much of the upper continental rise except for a silty area where Hudson Canyon cuts across the rise.

The most topographically complex areas on the continental shelf show a diversity of sediment type. As noted by Hathaway, Schlee, Trumbull, and Hülsemann (1965), silty clay and clay make up bottom sediment of many basins. Basins on the Scotian Shelf contain coarser grained sediment (silty sand) though it is still finer than that on the adjacent bank. The sampling grid intersected only a few topographic highs in the Gulf of Maine, but where it did, they are veneered by gravel, gravelly sand, or sand (pl. 1). Intervening areas of hummocky topography in the central Gulf of Maine are mainly mixtures of gravel, sand, silt, and clay in subequal amount. Hence, the sediment analyses plot in the central area of a ternary diagram (Shepard, 1954), as shown in figure 5. Adjacent to Nova Scotia, gravel and sandy gravel border the shelf, particularly to the southwest.

Shelf sand south of New England is quartzose, dusky yellow to yellow ochre (Stanley, 1969) and stained by iron oxide in some areas. The landward shelf sands are low in layer silicates (Woods Hole Oceanographic Institution, 1965, p. 70-72) and feldspar but contain as much as 4 percent glauconite. Offshore, the sand contains finer detritus, is greenish black, less quartzose, and richer in layer silicates; sediment similar in color mantles the sheltered inshore areas such as Long Island Sound and Raritan Bay. Bottom photographs show that the shelf sands are being reworked by waves and currents (Emery, Merrill, and Trumbull, 1965) to form oscillatory ripple marks off New Jersey and Long Island and asymmetrical ripple marks on 


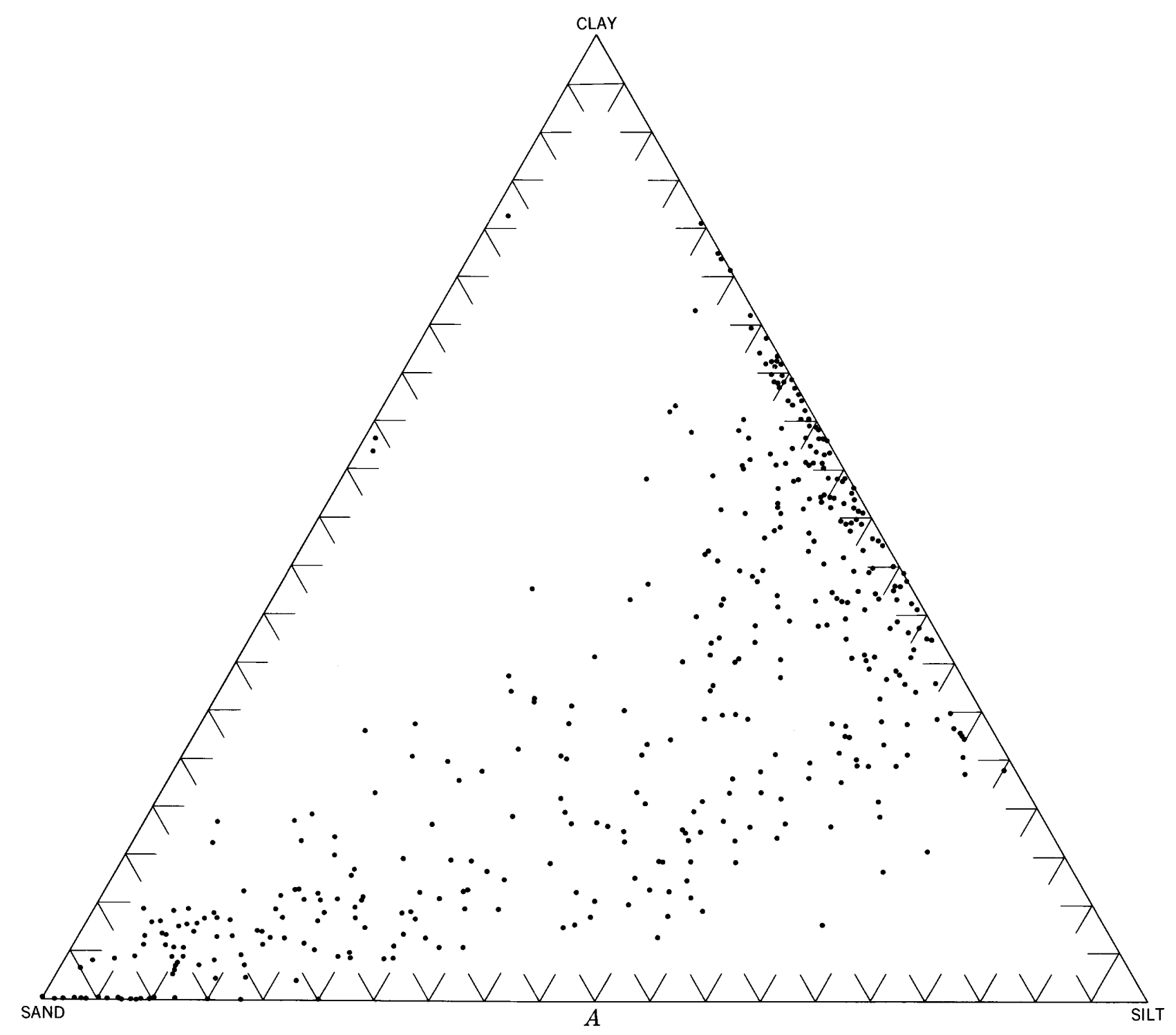

FIGURE 5.-Ternary textural diagrams of sediment from the continental margin off Northeastern United States. All

Georges Bank and Nantucket Shoals. They also show varying amount of shell debris and gravel mixed with the sand.

Basin sediment in tine Gulf of Maine and Scotian Shelf is a mixture of dusky yellowish-brown silt and clay (Hathaway and others, 1965) composed of chlorite, mica, mixed-layered mica montmorillonite, and minor quartz. The sand fraction is mainly mica and Foraminifera and other biogenic detritus. Photographic evidence shows biologic reworking of the sediment by brittle stars and worms; a few photographs taken in Great South Channel indicate current activity as shown by the alinement of tentacles on benthic sessile organisms.

Interbasin sediment in the Gulf of Maine is similar in appearance to the sediment in the basins
(Stanley, 1969), except that it has an increased amount of sand and gravel. Coarse detritus in the sand range is largely silicate detritus, such as quartz, feldspar, angular rock fragments, and dark minerals (Woods Hole Oceanographic Institution, 1964 , p. 88). Gravel is a mixture of many different kinds of crystalline and sedimentary rock types (Schlee and Pratt, 1970). In some areas, these bouldery till-like sediments are veneered by a finegrained layer of silty clay and sandy silt. (See section on "Sediment Geometry," p. L36.)

Sediment covering isolated banks and ledges in the Gulf of Maine is similar to the sediment on the shallow banks and shelves that surround the gulf in that it is coarse detritus, relatively high in quartz and feldspar and low in chlorite and mica (Woods 


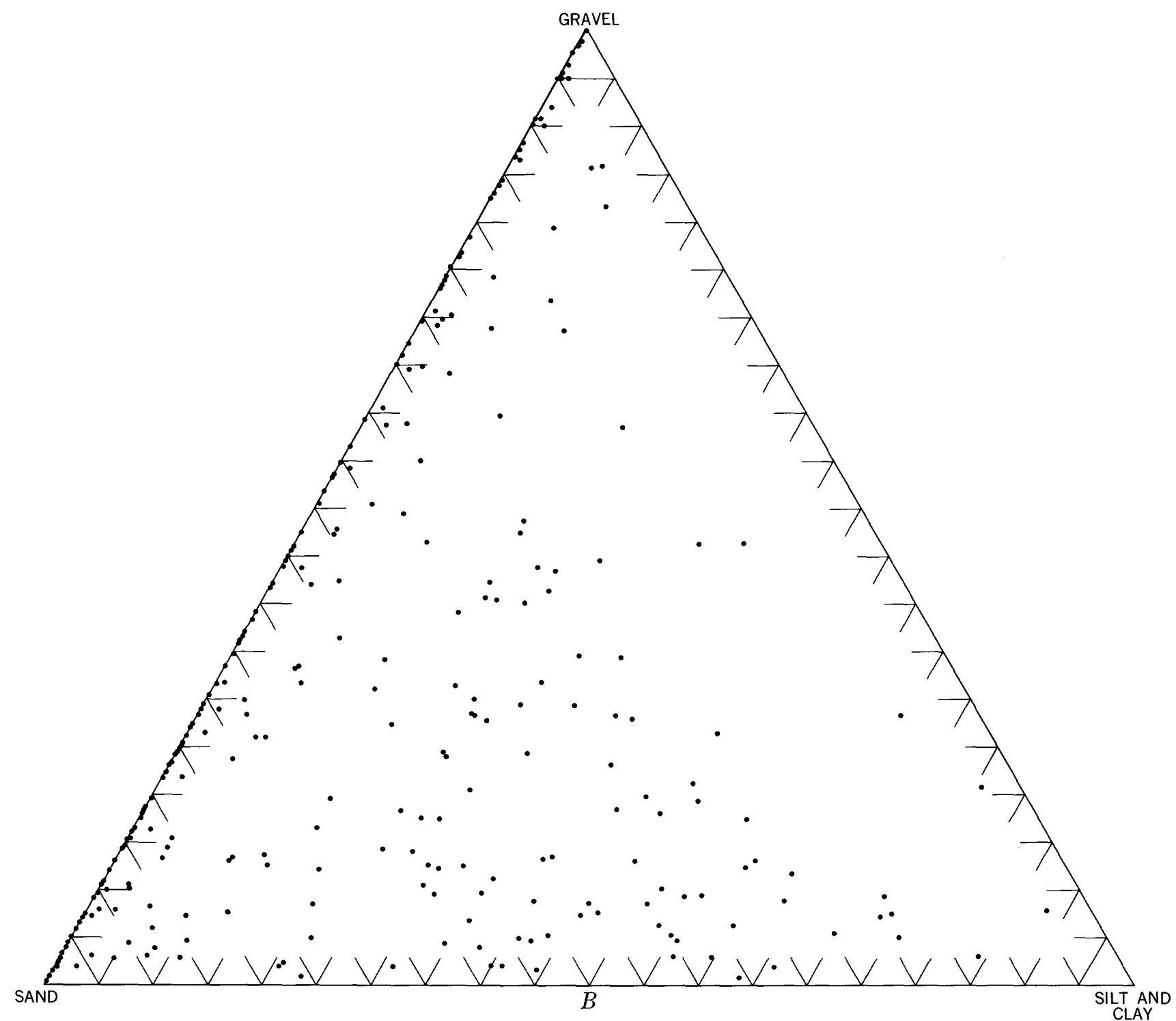

the samples with 1 percent or more gravel are plotted in $B$. Not shown on $A$ are 84 analyses of 100 percent sand.

Hole Oceanographic Institution, 1964, p. 89). Finegrained sediment in nearshore areas along coastal Maine is greenish-black clay and silt, mainly vermiculite; this sediment appears to reflect the contribution of rivers in the area (Woods Hole Oceanographic Institution, 1965, p. 71).

The continental slope and upper continental rise are covered by pale to grayish-olive silty sand and silty clay ( $\mathrm{pl} .1$ ) composed of quartz and moderate to low amounts of layer silicates (J. C. Hathaway, oral commun., 1969). A few samples contain more than 4 percent glauconite, particularly near outcrops of older formations adjacent to submarine canyons (J. V. A. Trumbull, oral commun., 1968). As in finer grained sediment of the Gulf of Maine, the slope shows moderate reworking of the surface by benthonic organisms, mainly polychaete worms, amphipods, brittle stars, and scaphopods. Obvious current structures are not evident, even though the currents are there (Emery and Ross, 1968; Schneider and others, 1967, fig. 2).

Similar sediment on the lower continental slope and rise shows a progressively larger calcareous fraction composed of planktonic Foraminifera. Accompanying the decrease in size on the slope and rise, is an increase in layer silicates and in the feldspar-quartz ratio (J. C. Hathaway, oral commun., 1969). The color changes from pale olive and grayish olive to pale-yellowish brown and duskyyellowish brown on the continental rise. Biogenic reworking again is the main activity on the sea floor. 
A textural plot (fig. 5) shows that certain types dominate and that gradations exist to bridge interareas between basic populations of sand, gravel, and silt plus clay. Sand is the dominant type of the four components, by virtue of its large areal extent over much of the continental shelf (pl. 1). A ternary plot of sand-silt-clay shows a broad swatch across the center of the diagram and the association of sand with differing amounts of silt and lesser amounts of clay. Along the silt-clay side, clay is slightly more abundant, particularly in deep water. Using the Shepard classification (1954), most sediments are sand, silty clay, clayey silt, silty sand, sandy silt, and sand-silt-clay. Other end members of clay and silt are not prevalent (only one sample contains more than 75 percent silt), and subdivisions between sand and clay are virtually unrepresented; hence they have been lumped in with adjacent sediment types on the map (pl. 1). The samples containing gravel show a concentration of points on the sand-gravel join (fig. $5 B$ ), reflecting the intimate association with sand over shoal areas of the shelf. Fully one-third of the samples containing gravel have a substantial component of silt and clay, as well as sand. These samples come mainly from the Gulf of Maine (pl. 1) where sorting is poor and size of fragments can be extremely large (Schlee and Pratt, 1970).

The distribution of points on a ternary diagram is similar to plots for other shelf areas (fig. 6), but the northeast Atlantic continental margin shows more sand and coarse sediment than the Gulf Coast continental margin though less silt than the Mississippi delta area. Coarse detritus is much more prevalent on the northeastern Atlantic continental margin (fig. 5) than other offshore areas (fig. 6) because of glaciation in the northern part.

Areal distribution of sediment types (pl. 1) and different size fractions (pl. 2) emphasize several points: (1) most of the continental shelf is covered by sand, (2) the amount of silt and clay increases in deeper areas, such as basins in the Gulf of Maine, the continental slope, and continental rise, (3) an

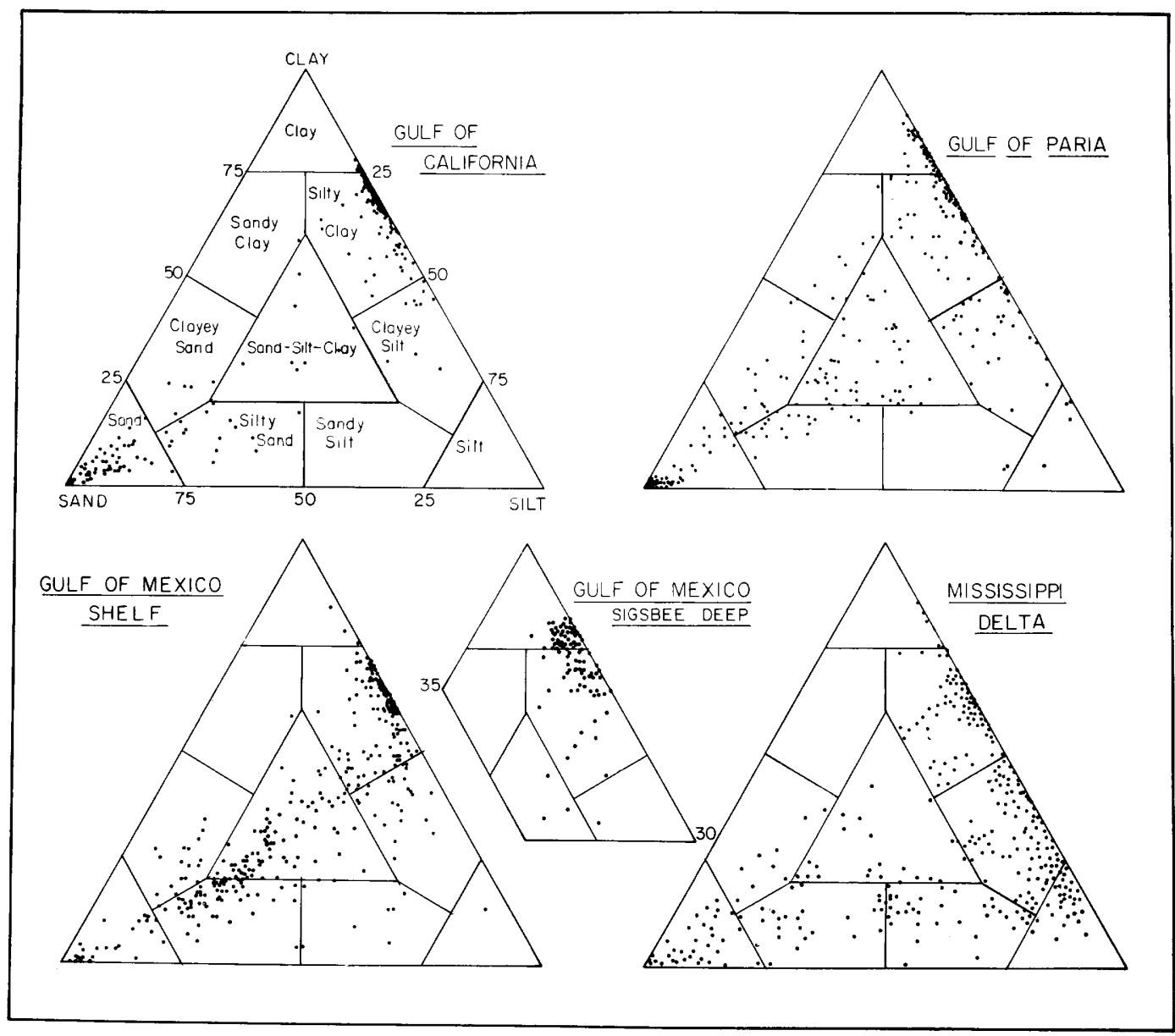

FIGURE 6.-Ternary textural diagrams of sediment from the Gulf of California, Gulf of Paria, and Gulf of Mexico (from van Andel, 1964). 
imperfect gradation exists between areas of coarseand fine-grained sediment, and (4) coarse gravelly sediment is mainly in the northern glaciated part of the continental margin.

\section{STATISTICAL MEASURES}

Statistical measures of grain-size distribution allow a closer look at the areal distribution of bottom sediment in light of different source areas and depositional agents (pls. 2, 3 and figs. 7, 9). It also supplements the descriptive features (patchiness, sediment type) already mentioned.

\section{MEDIAN SIZE}

Median grain size (pl. 2) broadly mirrors the map of sediment type (pl. 1) in that areas of sand, clay, and gravel are evident on both, tending to indicate the importance of these "end" member types. A broad arcuate pattern in the coarse to medium sand covers the shelf south of Long Island, festooning from Nantucket Shoals across Great South Channel and Georges Bank to Browns Bank. Median sizes are in the fine sand range on the seward part of the shelf south of Cape Cod and in irregular area of southeastern Georges Bank. A coarser median size is evident along limited parts of the shelf break southeast of Cape Cod; it is even more obvious on maps of the dominant sediment mode (fig. 7). Median size is in the silt range on the slope and in the clay range on the rise. Isolated anomalies on the lower slope and in some canyons reflect one or two samples of coarser grain size in an area of finer grained sediment. Yet some of these anomalies may

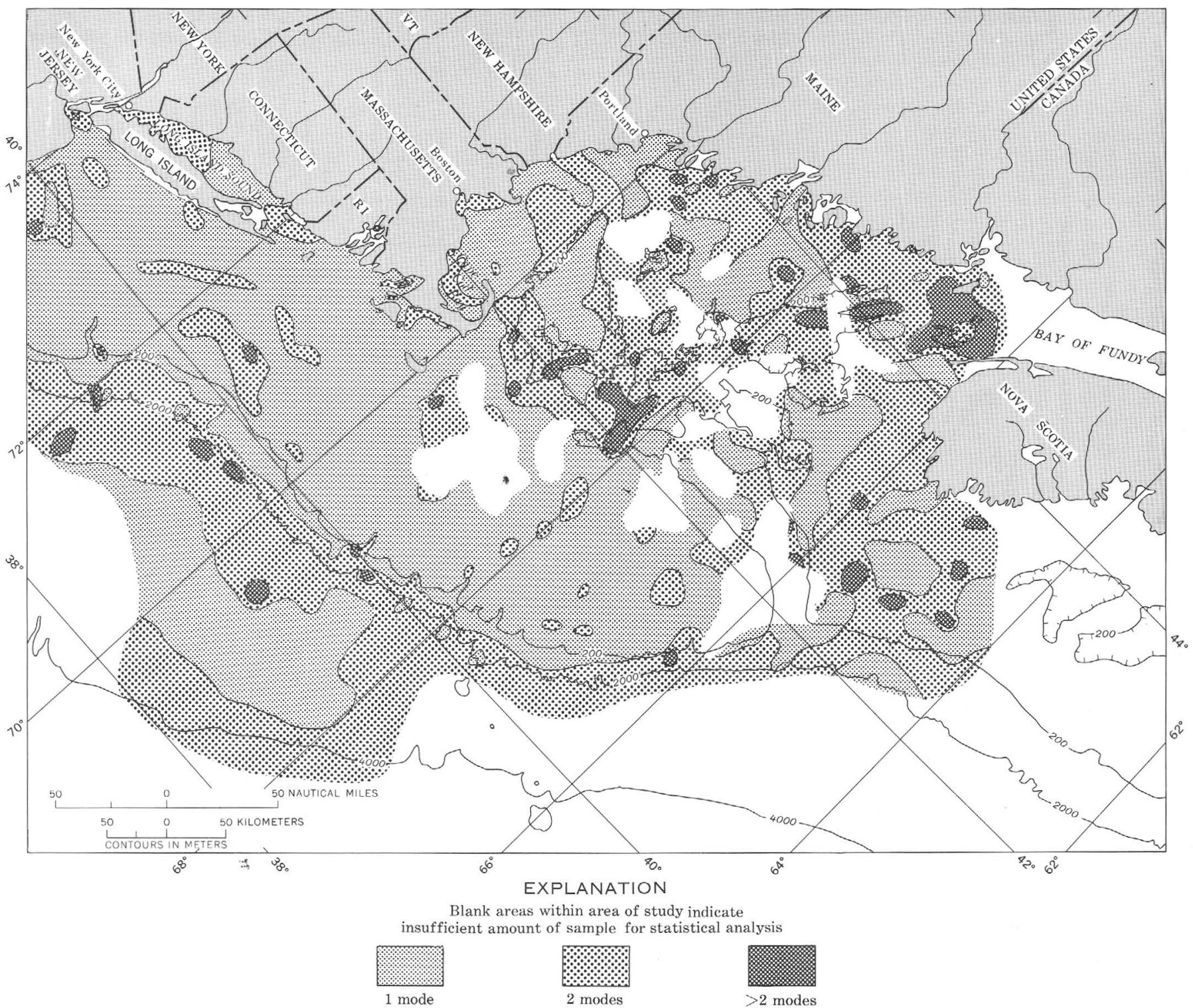

FIGURE 7.-Number of modes in grain-size distribution for sediment samples on the continental margin off the Northeastern United States. 
relate to small topographic features such as the ridgelike features on the lower continental slope covered with gravelly sand and described by Emery and Ross (1968). A comparison of plates 1 and 2 shows that the median is a fairly reliable measure of bottom sediment, this despite the fact that in some areas the sediment is not normally distributed. Shepard and Cohee (1936) and Stetson (1938) and Wigley (1961) have plotted maps of median size on the shelf or made profiles of median grain size versus depth. Shepard and Cohee's (1936, pl. 3) map shows many of the same patterns as on plate 2 except that their map is more patchy on the shelf because they have more closely spaced samples and have contoured them on a whole phi interval. Wigley's (1961, fig. 5) map of Georges Bank also shows a similar pattern of high median values along the northern part of Georges Bank, Northeast Channel, and Great South Channel. Stetson's profiles (1938, figs. 6-8) out from the coastline into the Gulf of Maine show irregular though discernible decreases of median size with an increase in water depth.

POLYMODAL DISTRIBUTION

Much of the bottom sediment (fig. 7) has more than one mode (a size interval with more sediment than either of the adjacent size classes); as such, these additional modes can be a useful indication of mixing from multiple sediment sources or through different agents of transport. Modes have been used by Curray $(1960 \mathrm{a}, \mathrm{b})$ as a key to tracing different sediment contributions over the continental shelf on the Gulf Coast; Garrison and McMaster (1966) attempted the same type of analysis on the continental shelf off Rhode Island. Curray's analyses were made on a one-fourth-phi class interval, and modes were differentiated from cumulative grainsize curves. For this study, most analyses were made on one-phi class interval (a few sands were sized at a half-phi interval), and modes were lumped in a two-phi interval for purposes of presentation ( $\mathrm{pl}$. 3 ). The one-phi interval of size analysis probably did not detect all the modes; hence some sediment may be more polymodal than shown in figure 7 , though the general areas of polymodality on the shelf off Rhode Island overlap those indicated by Garrison and McMaster (1966). Further, in both their study and Curray's, a larger grouping of modes (one- or four-phi intervals) was necessary to portray modal distribution on maps.

Areal distribution of modes (pl. 3) shows a pattern similar to that already described for sediment type (pl. 1). Modes in the gravel and coarse-sand range are dominant in the glaciated continental margin (pl. 3). Some sediment is bimodal, with sand as a secondary admixture, and some is washed sorted unimodal gravel. At the entrance to the Bay of Fundy, gravel is part of the multimodal mixture along with sand, silt, and clay. Southeast of this area, gravel is the dominant mode in association with sand on the rocky hummocky shelf southwest of Nova Scotia. As a modal size contribution (fig. 8 ), gravel is minor, in part because of its occurrence

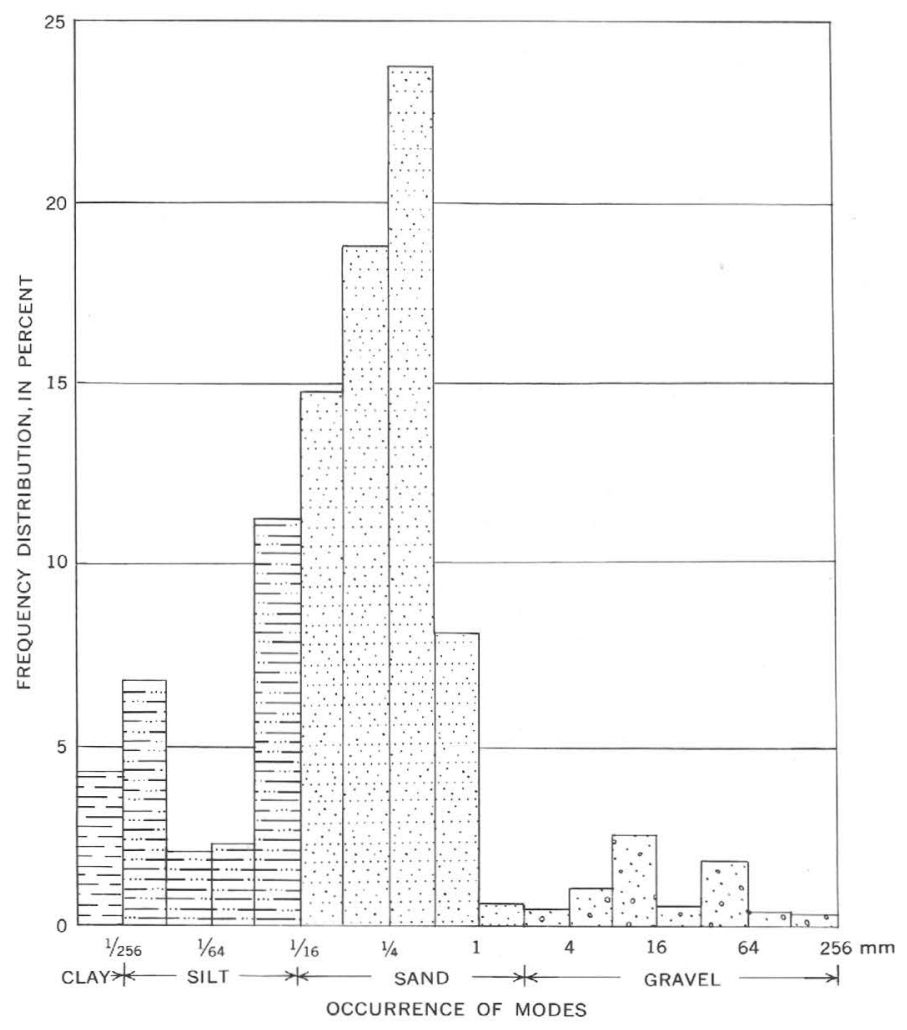

FIGURE 8.-Histogram of the occurrence of modal grain size. Notice the saddles in the range of medium-coarse silt and coarse sand-fine gravel.

with larger amounts of sand, and also because of the difficulty in sampling coarse detritus (Schlee and Pratt, 1970).

Hardly any modes are in the very coarse sandgranule ranges (pl. 3 and fig. 8). The scarcity of modes here lends support to the idea that grains in this interval tend to be unstable aggregates that disintegrate into sand grains (Pettijohn, 1957, p. 50). It also supports Spencer's (1963) idea that sand and gravel are basic parent populations.

Because of the sand-covered continental shelf, most grain-size modes are in the sand range $(651 / 2$ percent); the patterns again broadly relate to the bathymetry and to past geologic events. Georges Bank and the shelf south of New England show broad indistinct alternating bands of coarse and fine sand. The thin band of coarse sand along the 
inshore shelf off southern Long Island, Rhode Island, and Cape Cod is close to sandy moraines along the coast and probably derives much detritus from the glacial deposits. Offshore for about $50 \mathrm{~km}$, sand has a finer modal grain size in the area of intricately developed sand ridges which trend east-west and intersect the Long Island shoreline at a low angle (fig. 2).

Most of the outer continental shelf south of Long Island, Nantucket Shoals, and northern Georges Bank is veneered by sand with a coarse modal grain size; the sand is associated with relict topography and deposits south of Long Island (fig. 2) and the Franklin and Nichols scarps along the shelf edge. The band of coarse sand divides around an area of finer sediment south of Rhode Island and Cape Cod and continues eastward on the outer shelf edge (an area of lowered sea-level stands) and along the inner shelf south of Massachusetts (pl. 3). Like the bank adjacent to Long Island, the one southeast of Cape Cod is associated with extensions of glacial moraines on Martha's Vineyard and Nantucket and probably has its source from these deposits. The same is likely to the east, where coarse sand veneers almost all of the complex shoal topography (sand waves and tidal ridges) on the northern part of Georges Bank.

Sand with a fine to medium modal grain size $(1 / 2-1 / 16 \mathrm{~mm})$ is in transitional zones of fine sediment. The largest of these areas is a belt south of Rhode Island and Cape Cod where it (pl. 3) encompasses two areas of silt on the shelf. Modal grain size of the sand tends to be finer $(1 / 8-1 / 16 \mathrm{~mm})$ adjacent to the silty areas and coarsest toward glacial deposits of southern New England and Nantucket Shoals. A change toward finer modal sand size is also along the northern edge of Georges Bank down into Georges Basin. Within the gulf, modal sand size shows no regional gradients.

As might be expected from the sediment type (pl. 1 ), dominant modes for silt and clay are mainly in deeper areas-the continental slope, rise, and basins of the Gulf of Maine (pl. 3). Modes in the coarse silt range border sandy sediment of the upper slope and shelf as a thin band and extend down to the lower part of the slope and upper continental rise. Distribution of modes in these fine sediments is irregular between Hudson Canyon and the New England seamount chain; coarser sediment mantles the rise near Hudson Canyon and on the upper rise south of Georges Bank (pls. 1 and 3). The finest grain-size modes detected are in Wilkinson and Murray Basins; silty clay with modes in the 16-4 micron $(1 / 64-1 / 256 \mathrm{~mm})$ range surrounds the basins and suggests a transition to and source from the heterogeneous glacial deposits that flank the basins. In the two largest basins of the eastern Gulf of Maine, modal size shows no transition from clay to gravel. The variability in modal size likewise carries through into sediment type, in both Jordan and Georges Basins where till-like mixtures of clay, silt, sand, and gravel (Georges Basin) and clay and silt are evident.

The major geologic importance of modes lies in their use to interpret patterns of sediment dispersal. Attempts to trace patterns of modal size change have been used by Curray (1960b) over the TexasLouisiana continental shelf and by Garrison and McMaster (1966) over the southern New England continental shelf. In the present study, the gradients of modal grain size have been compared with the shelf pattern of bottom-current drift to see how well they relate; implicit in the approach is an attempt to see how effective bottom currents have been in dispersal of sediment on the shelf. The map of modal gradient was constructed from plate 3; where three or more modal ranges (two-phi interval) form a consecutive sequence over a relatively limited distance $(20-30 \mathrm{~km})$, an arrow has been drawn to indicate the vector azimuth. The results (fig. 9A) show pronounced gradients down the continental slope and down the sides of large basins in the western Gulf of Maine. On the shoal areas of the continental shelf, grain size becomes progressively finer from the shoals, as on Georges Bank, toward the deeper parts of the shelf, but over most of the shelf and on the upper part of the continental rise, no dominant pattern is evident. In the estuarine areas, and sheltered bodies of water like Long Island Sound, gradients are toward the head of the estuaries from areas of coarser modal size on the shoreward part of the shelf in patterns similar to that described by Jordan (1968) and Duane (1964). The gradients are seaward out the mouths of two of the largest rivers in New England, the Merrimac and the Kennebec. Along with that of the Penobscot, sediment from these rivers is reflected in the heavymineral assemblages found in adjacent parts of the Gulf of Maine (Ross, 1967).

A comparison of figures $9 A$ and $9 B$ shows only a few places where the two maps show similarity between residual bottom drift and modal gradients. The few are in shallow estuaries or bays (Raritan Bay, Narragansett Bay, Long Island Sound), a few areas on Georges Bank, and in the Gulf of Maine. This lack of similarity suggests that the gradients in size were inherited from earlier episodes of sedimentation and that, except for some inshore 


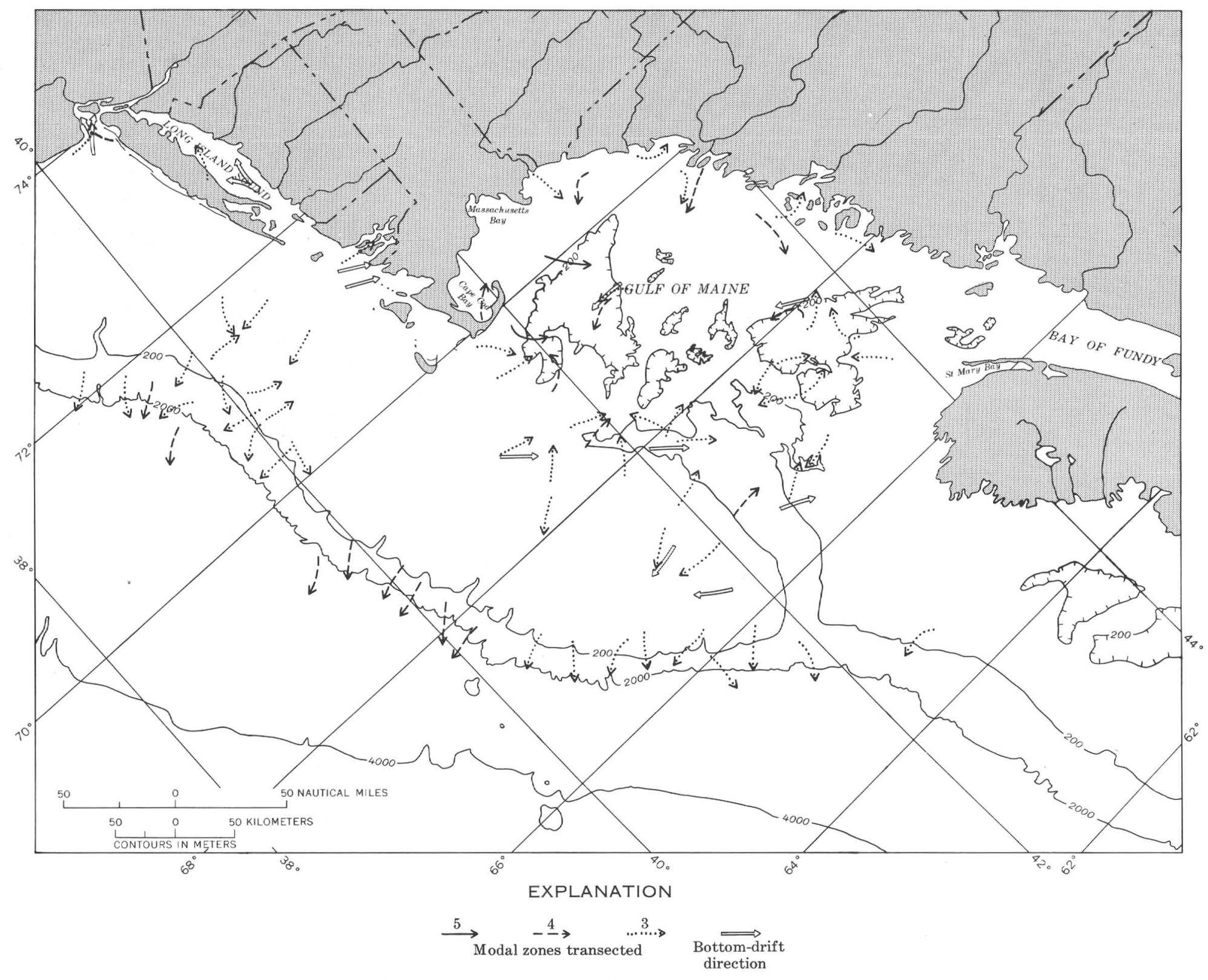




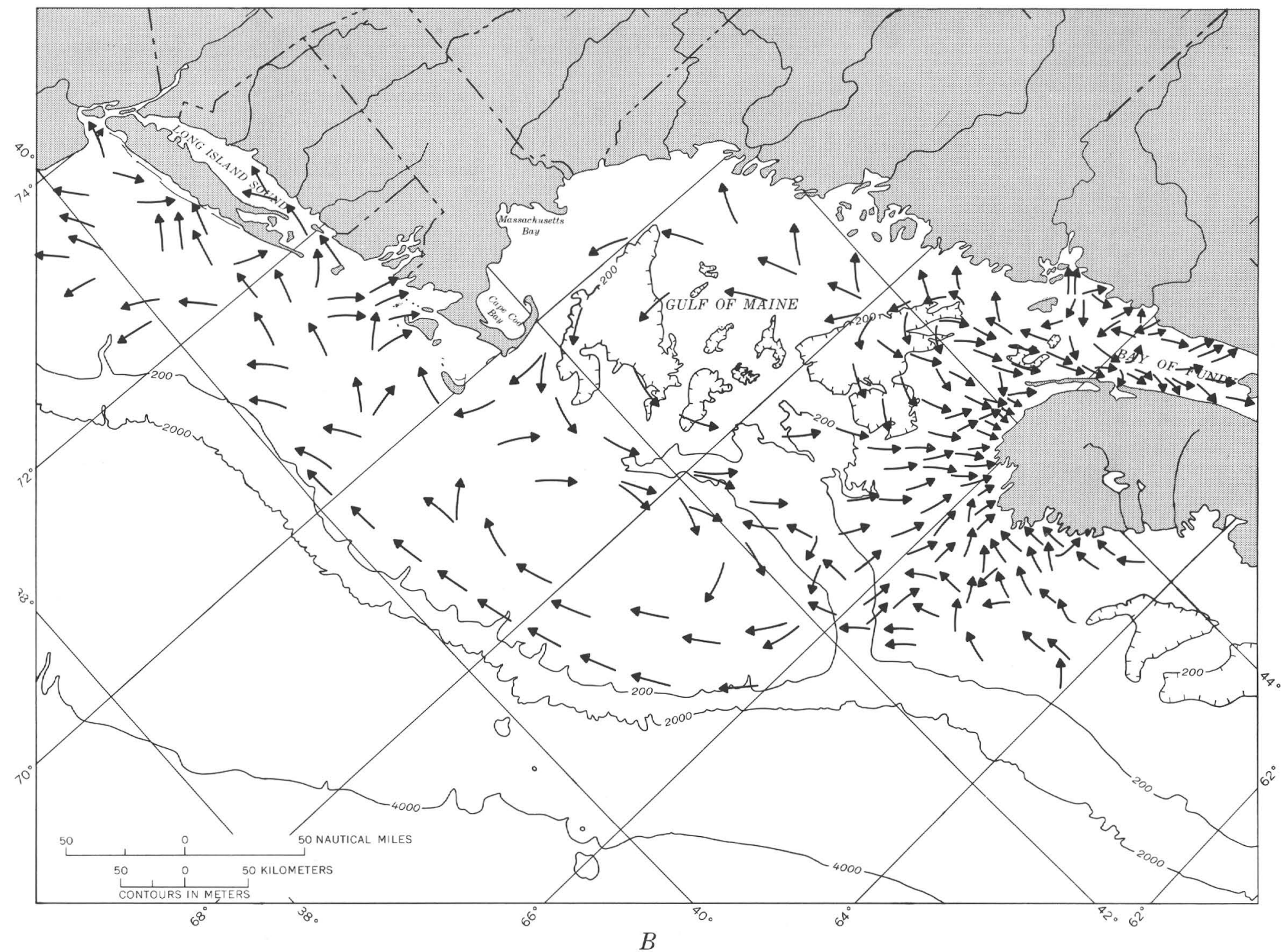

FIGURE 9.-Maps showing patterns of potential sediment transport. $A$, gradients of changing modal size. Arrows point toward finer grain size. Modal zones (two Wentworth size intervals) are those shown on plate 3. Open arrows are the bottom drift directions $(B)$ that subparallel the modal gradient arrows. $B$, directions of residual bottom-current drift. Length of arrow has no significance. Data from Bumpus (1965), Lauzier (1967), and R. D. Muench (unpub. data, 1966). Directions in the central Gulf of Maine and on Georges Bank are considerably less certain than directions south of Long Island, Cape Cod, and Nova Scotia because they are inferred from surface drift rather than measured directly by seabed drifters. 
areas, residual bottom drift has not greatly modified these relict sediment patterns. An alternative explanation is that the modal gradients show movement of sediment during heavy storms and hurricanes rather than day-to-day bottom-current movement possibly reflected by the seabed drifters. One might expect more modification of relict topography by sand drift than is apparent over the shelf, if storm surge had dispersed the sediment.

The pronounced modal size gradients down the continental slope could be taken as a progressive sorting phenomenon, and yet the sediment becomes multimodal toward the lower part of the slope (fig. 7 ). This change indicates a possible mixing of additional sediment components (multiple sources) or modification of the distribution by further reworking of the sediment.

\section{SORTING}

Sorting of sediment can be helpful in pointing out the agents that deposited it. Moderate to good sorting characterizes the shelf sediment (pl. $4 A$ ) as shown by the low number of Udden size grades needed to contain the size distributions. Bottom cur- rents have winnowed and sorted much of the shelf sands, to judge from the bottom photographs of rippling and shell windrows mentioned earlier. Elsewhere, admixtures of silt or gravel lead to moderate or poor sorting shown by some areas of the shelf ( $\mathrm{pl}$. $4 A$ ).

Sheltered areas of the shelf such as Narragansett Bay, Long Island Sound, Raritan Bay, and Buzzards Bay also trend toward moderate or poor sorting, in the same direction that modal grain size becomes finer.

Poorest sorting is associated with the pebbly tilllike sediments in the Gulf of Maine. Bottom photographs show that subsequent sedimentation has dusted some of the till-like mixtures of sediment, but the poorly sorted mixture persists beneath a veneer of fine silt.

A scatter plot of median grain size versus standard deviation shows a crudely sinusoidal relation (fig. 10). This relation was noted by Folk and Ward (1957), who attributed it to the paucity of sediment in the coarse silt- and granule-size ranges. Sediment with a median grain size in either of these intervals

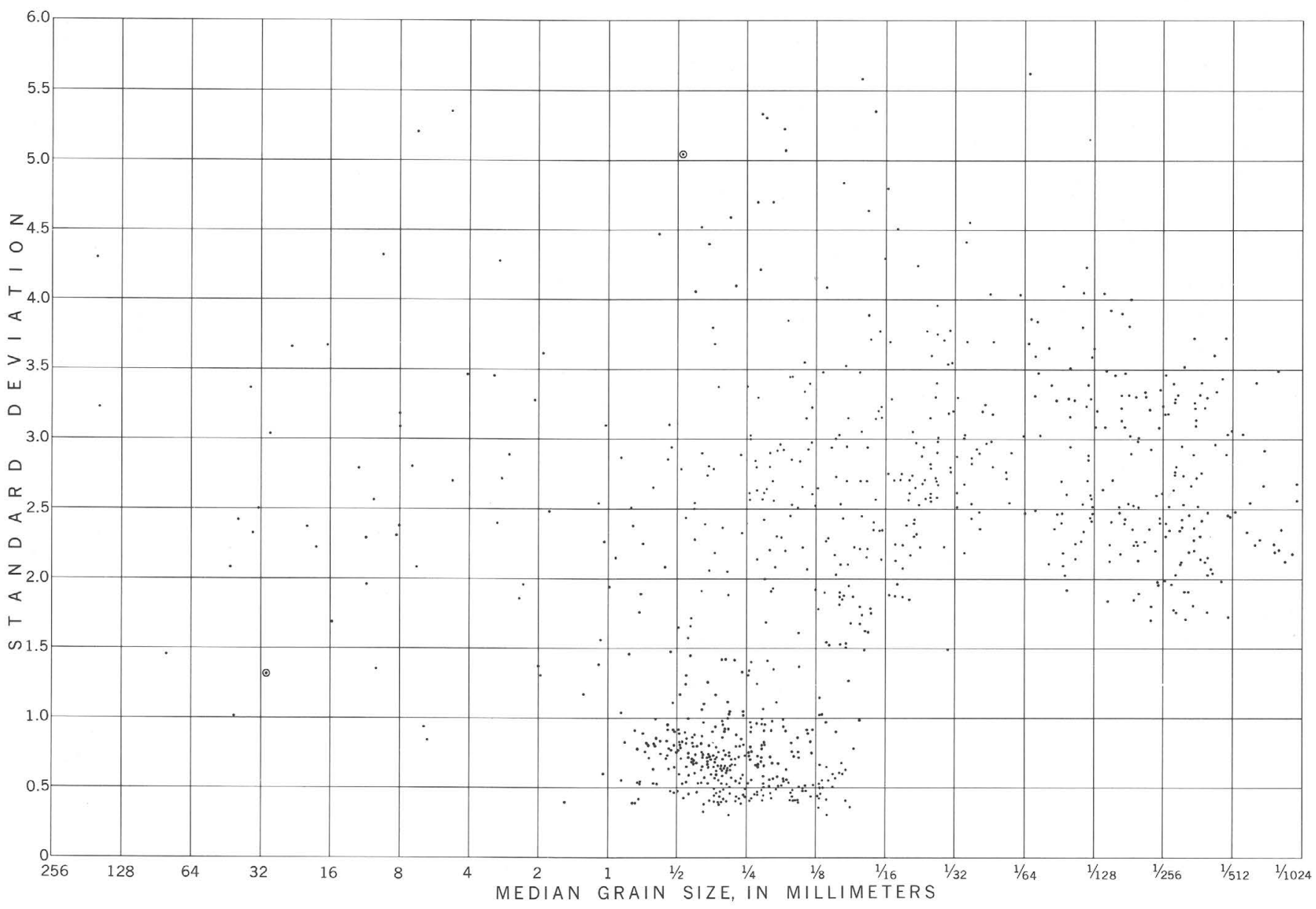

FIGURE 10.-Scatter plot of median grain size versus standard deviation (sorting). 
tends to be more poorly sorted than "pure" sand, gravel, or clay because the sediment is a mixture from two of these three basic size populations. The trend in figure 10 is more scattered than that shown by Folk (1964) because the till-like sediment from the Gulf of Maine is included. Ice transport probably would not tend to diminish coarse silt or granules the way rolling or saltation in a tractive current would. Hence, though the basic gravel-sand-clay populations show up (fig. 8), they are probably not as clearly defined as they would be if the glacially deposited sediments had been deleted.

\section{SKEWNESS}

Skewness of grain size relates very poorly to other sediment properties; its main contribution is to support the idea of the mixing of basic populations of sand, gravel, and silt plus clay. Values range from 1.6 to -1.1 and are mainly concentrated toward the positive range of skewness (tail of fine-grained sediment). The mottled pattern of skewness (pl. $4 B$ ) might be anticipated in the Gulf of Maine from maps of sorting, modes, and sediment type, but it is also prevalent on the rest of the shelf.
In a few areas, skewness values show a systematic relation to other textural properties of the sediment. The fine-grained sediments south of Cape Cod and Rhode Island are positively skewed (a tail of fines), as are those on the outer shelf and upper continental slope in the same areas. The material in this area is silty sand, and it tends to be moderately sorted. Negatively skewed sediments (tail of coarse grains), as gravelly coarse sandy detritus, covers some areas, especially in Great South Channel, Nantucket Shoals, east of New Jersey, south of Long Island, and on part of the Scotian Shelf.

As a measure of the asymmetry of a normally distributed population, skewness has been used to indicate the mixing of two sediment populations (Hayes, 1966 ; Chappell, 1967), or progress in winnowing of a parent population (Hough, 1942 ; Spencer, 1963; Friedman, 1967; Swift, 1969), and as an environmental indicator (Folk and Ward, 1957; Mason and Folk, 1958; Friedman, 1961, 1967; Chappell, 1967; Moiola and Weiser, 1968). Significantly, skewness values also may vary depending on the formulae used (Chappell, 1967), the interval at

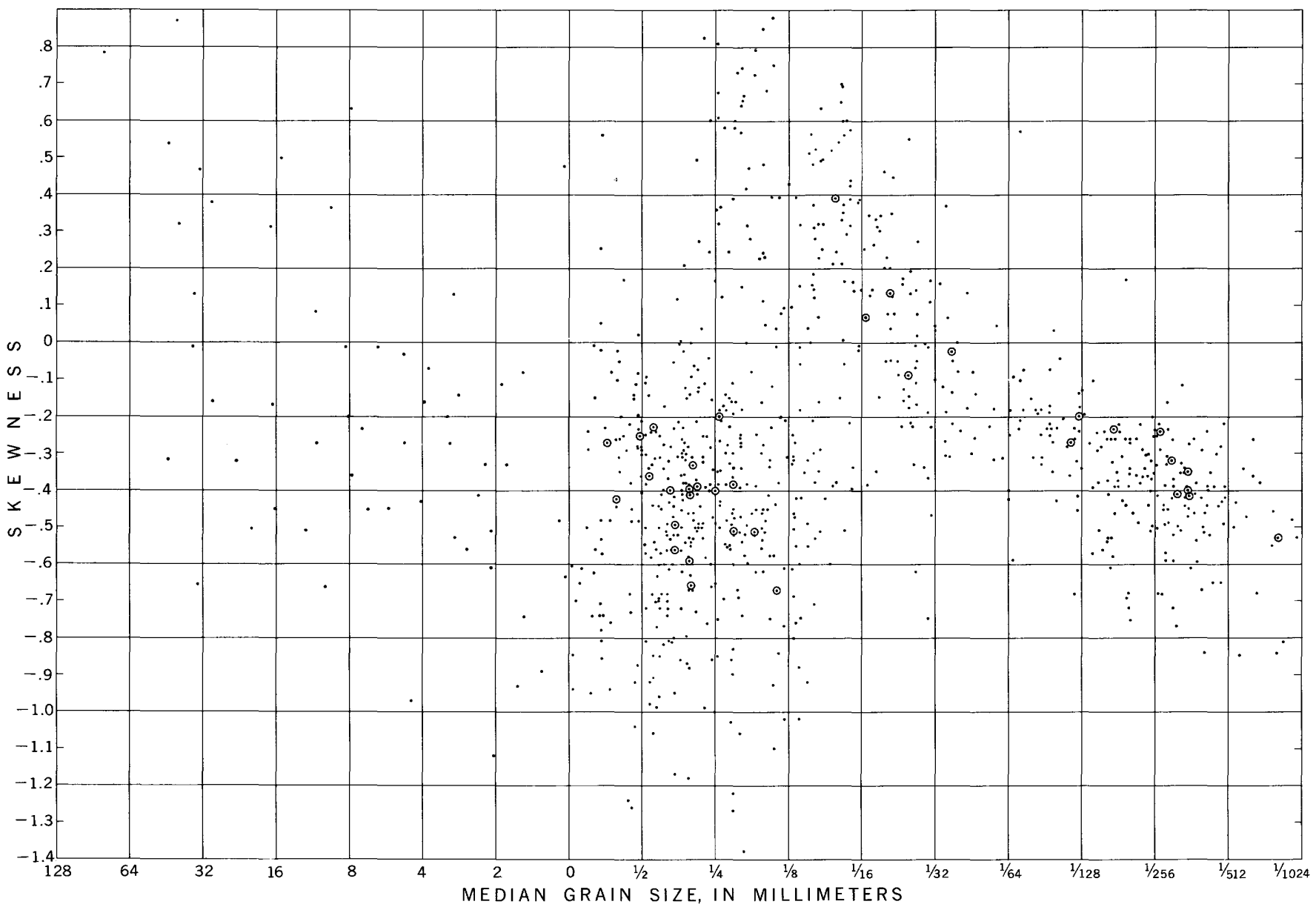

Figure 11.-Scatter plot of skewness versus median grain size. Circled points indicate superposition of two values. 
which data points are taken (Schlee and Webster, / of process and source factors; the same approach is 1967; Moiola and Weiser, 1968), and the method of analysis (Folk, 1962; Schlee and others, 1964). Most investigations of skewness have plotted it versus other statistical parameters to show the importance used here.

A plot of skewness versus median grain size ( $\mathrm{fig}$. 11) indicates the importance of basic sand and clay populations to skewness. The distribution shows a

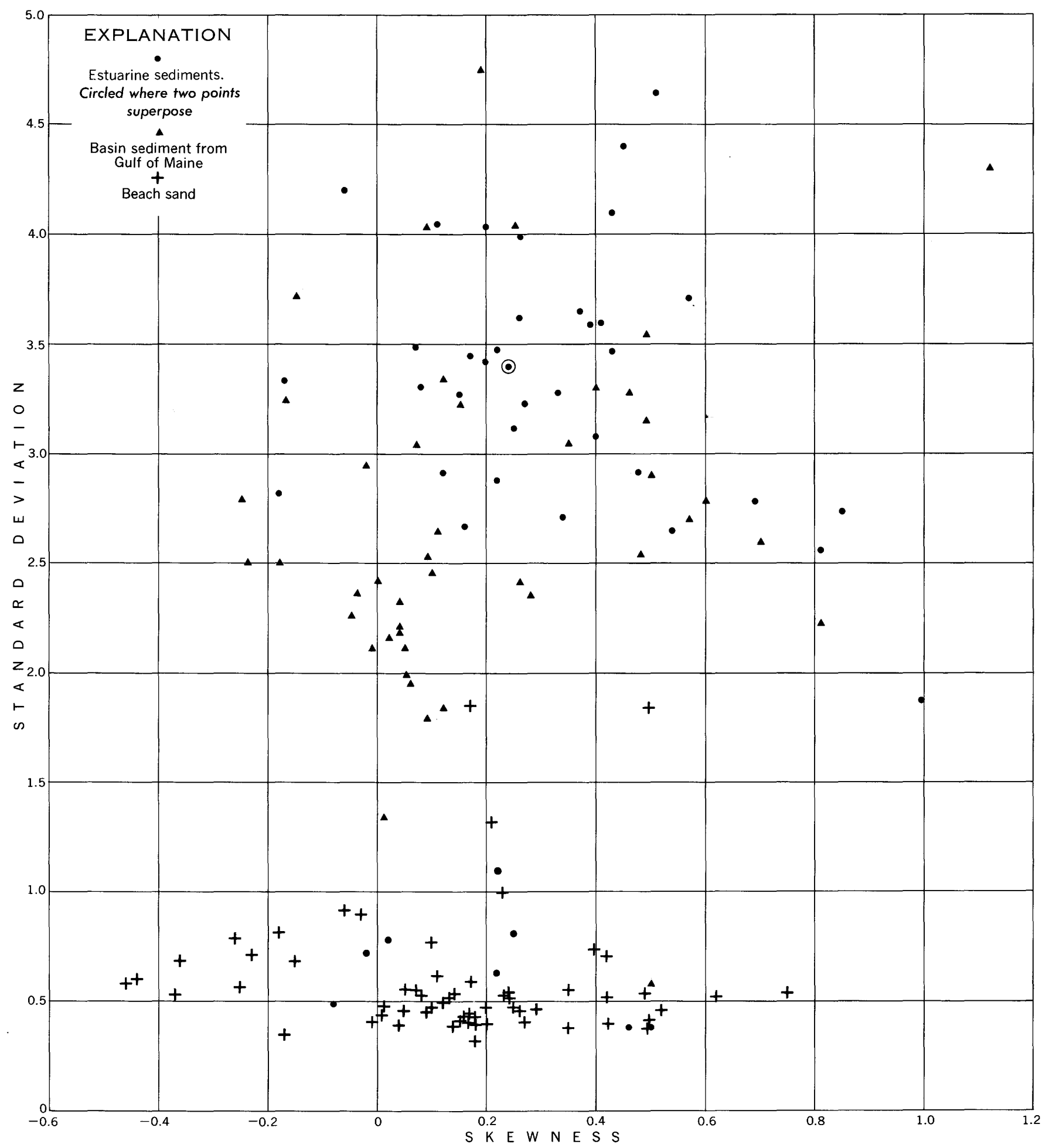

FIGURE 12.-Scatter plot of skewness versus standard deviation for estuarine sediment, basin sediment from the Gulf of Maine, and beach sands. 
cluster of values bracketing the interval of -0.1 to 0.3 in skewness for sediment with a median size in the sand range. Likewise it shows a similar clustering in the clay range. In between clay and sand, skewness values arch up into the positive range where mixing of the two populations has occurred and the sand populations become dominant. A cluster in the gravel field is not evident perhaps because of a paucity of median values in gravelly sediment. The scatter of points is wide and the sinusoidal rela- tion to skewness and size noticed by Mason and Folk (1958, fig. 12) is indistinctly formed.

A plot of skewness versus standard deviation (figs. 12 and 13) shows a clear separation of current-deposited sand of the beach and shallow marine areas from (1) sheltered estuaries and bays, and (2) basins of the Gulf of Maine.

Beaches show excellent sorting and a slight admixture of fine detritus (positive skewness) in with the sand. The positive skewness contrasts with slightly

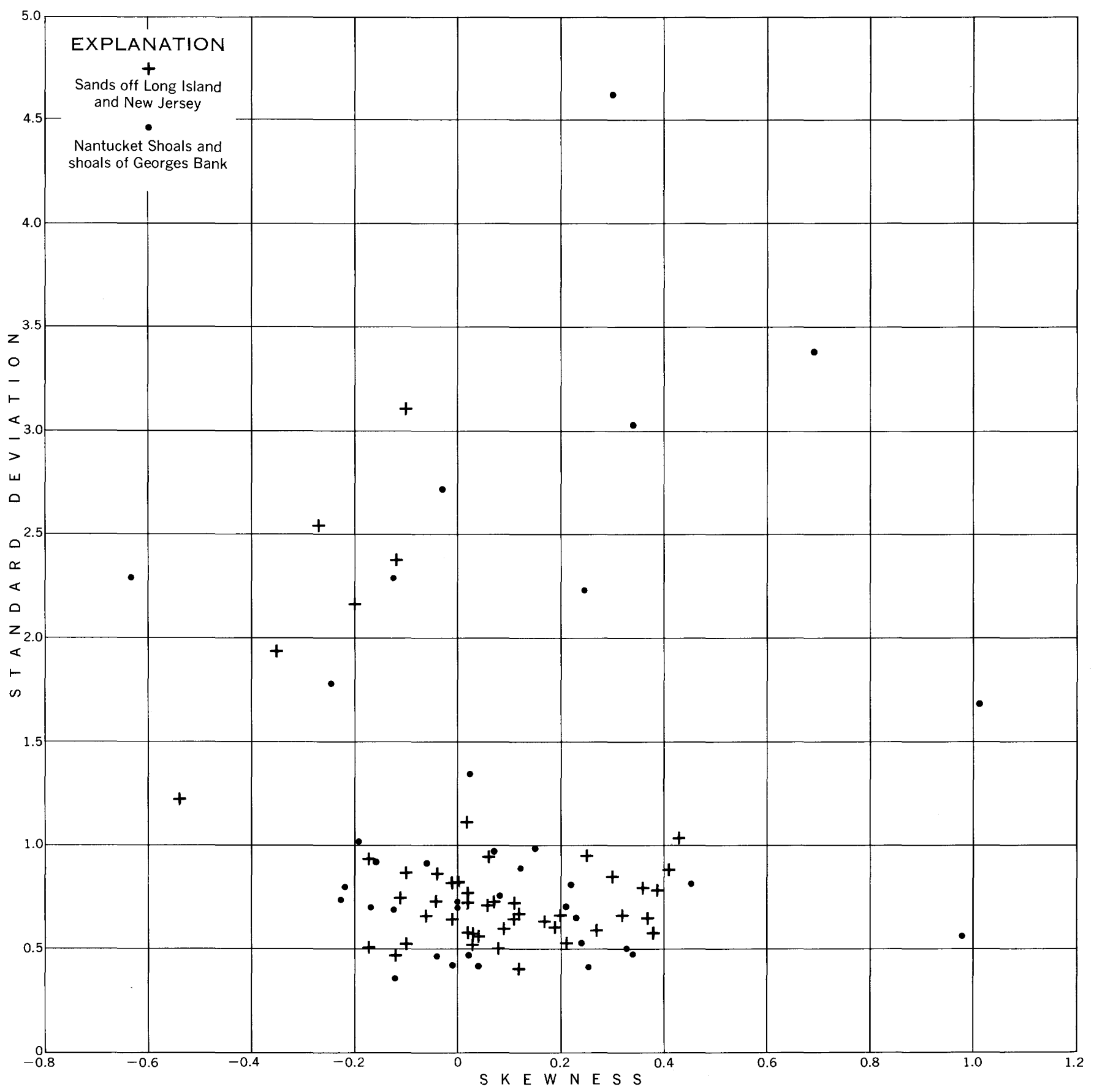

FIGURE 13.-Scatter plot of skewness versus standard deviation for nearshore sand and gravel. 
negative values found by Biederman (1958), Folk (1966), and Friedman (1967) and in part reflects the settling-tube method of analysis and perhaps mixing of positively skewed eolian sands with the beach sand; high-velocity winds during the winter do tend to be offshore and could promote mixing of beach and eolian sand in a manner similar to that described by Chappell (1967) in New Zealand. The diagram (fig. 12) also shows the influence that the source of the clastic detritus can have. Most of the values in the cluster of beach samples come from the New Jersey-Long Island coast, an area underlain by sedimentary formations of the Atlantic Coastal Plain-formations which doubtless contribute to beach deposits (McMaster, 1954). The range of grain sizes available along the coasts of Rhode Island, Connecticut, Massachusetts, New Hampshire, and Maine is much larger because of the proximity of crystalline bedrock and coarsegrained glacial deposits. Hence, along New England beaches where size can range widely (high standard deviation), skewness values (positive to negative) can also, depending on whether the sand or gravel population is the major fraction.

Estuarine sediments are much more poorly sorted and are positively skewed. Coarse fractions are poorly represented (pl. 2), but silt and clay (pl. 2) are present; thus there is a wide spread in grain size and a tailing off into finer sizes to yield positive values of skewness. A few points plot in with the beach sands, but most of these are sands obtained well up the rivers proper where channel flow may have been more effective in sorting.

The plot of standard deviation versus skewness (fig. 13) for nearshore shelf sands shows broad overlap with beach sands, apparently because of similar sources and similar modes of transport by bottom currents. Most of the fine to medium sands of the New York Bight are restricted in their sorting range and show low positive to low negative skewness; those values that do range widely, are mainly from the iron oxide-stained gravels off New Jersey. In the Georges Bank-Nantucket area, the textural properties range more widely because the sands are more gravelly (negative skewness and higher standard deviation). The variation is much greater (figs. 12 and 13) than in the nearby beach sands. Constant winnowing and sorting of detritus on beaches has better segregated the basic sand population than in off-shore areas where currents and wave surge rework the bottom.

\section{KURTOSIS}

Kurtosis shows an even more patchy pattern (pl.
$4 C)$ than skewness and less interpretable in map form. Some insight is gained into the geologic contribution of the parameter in scatter plots versus other parameters. As a statistical measure, it is a measure of the sorting for the flanks of the size distribution, with respect to the central part. A very peaked distribution (well-sorted central part, poorly sorted flanks) has a high positive value, and a flattened frequency curve (better sorted flanks and more poorly sorted central part) has a negative value. The geological significance of kurtosis is in its use as a possible indicator of mixing of sediment populations such as sand and gravel (Folk, 1964, 1966). It has also been used in combination with skewness to differentiate beach and wind deposits (Mason and Folk, 1958) on the Texas coast; however, other attempts to utilize this combination have been less successful (Schlee and others, 1964 ; Friedman, 1967; Moiola and Weiser, 1968).

Polymodality of bottom sediment and kurtosis should show some overlap if kurtosis is an indicator of mixing of sediment populations. A comparison of plate 2 (median) and figure 13 shows that most areas of multimodal sediment broadly coincide with values of negative kurtosis. Most all high positive values of kurtosis are in areas of unimodal size distribution.

A plot of skewness versus kurtosis (fig. 14) shows a recumbent U-shaped pattern similar to that noted by Folk and Ward; selective analysis of the pattern appears best interpreted as the result of mixing of basic sediment populations. Skewness ranges from extremely positive to negative values, but the heaviest concentration is from 0 to 0.2 . Approximately 10 percent of the data points were examined to see if the U-shaped pattern was related to water depth or to particular parts of the continental margin. Points out on the flaired part of the plot showed no areal or depth control; these points represent sediment from water depths ranging from 33 to $505 \mathrm{~m}$-from shoals in the Gulf of Maine to the upper continental slope.

Figures 15 and 16 attempt to evaluate environmental, source area, and mixing factors. Figure 15 shows the large overlap of beach sand, estuarine silts, and the pelagic deposits of basins in the Gulf of Maine. The plot is far less effective than skewness versus standard deviation (fig. 12) in separating different milieus of deposition, a fact noted by Friedman (1967) and Moiola and Weiser (1968) for river, beach, and dune sands. As in figure 11, there is a marked tendency for beach sands along the Coastal Plain to have a very restricted range of kurtosis $(-0.8$ to -0.3$)$ and skewness. 
To evaluate the mixing factor, a plot was made of nearshore sands and gravelly sands from Georges Bank, Nantucket Shoals, and the shelf adjacent to Long Island and New Jersey; it shows a concentration of points in the area of low skewness and low kurtosis that trails off as a scatter of points toward the fields of high positive kurtosis and negative or positive skewness (fig. 16). As in the plot of skewness versus standard deviation (fig. 13) different sources (Coastal Plain-glacial outwash) for the nearshore sands do not appear to have caused a clustering of points. Most of the scatter of points (fig. 16 inset) is caused by admixtures of gravel; sand clusters around a nearly symmetrical distribution with a slightly flattened central part. Gravelly sediments form a broad V-shaped envelope to the sand. As is shown schematically by the scatter plot, the gravel goes from a subordinate admixture in the field of negative skewness and positive kurtosis, to a subequal amount with sand (zero kurtosis and negative skewness), to a dominant fraction with positive kurtosis and skewness. This trend

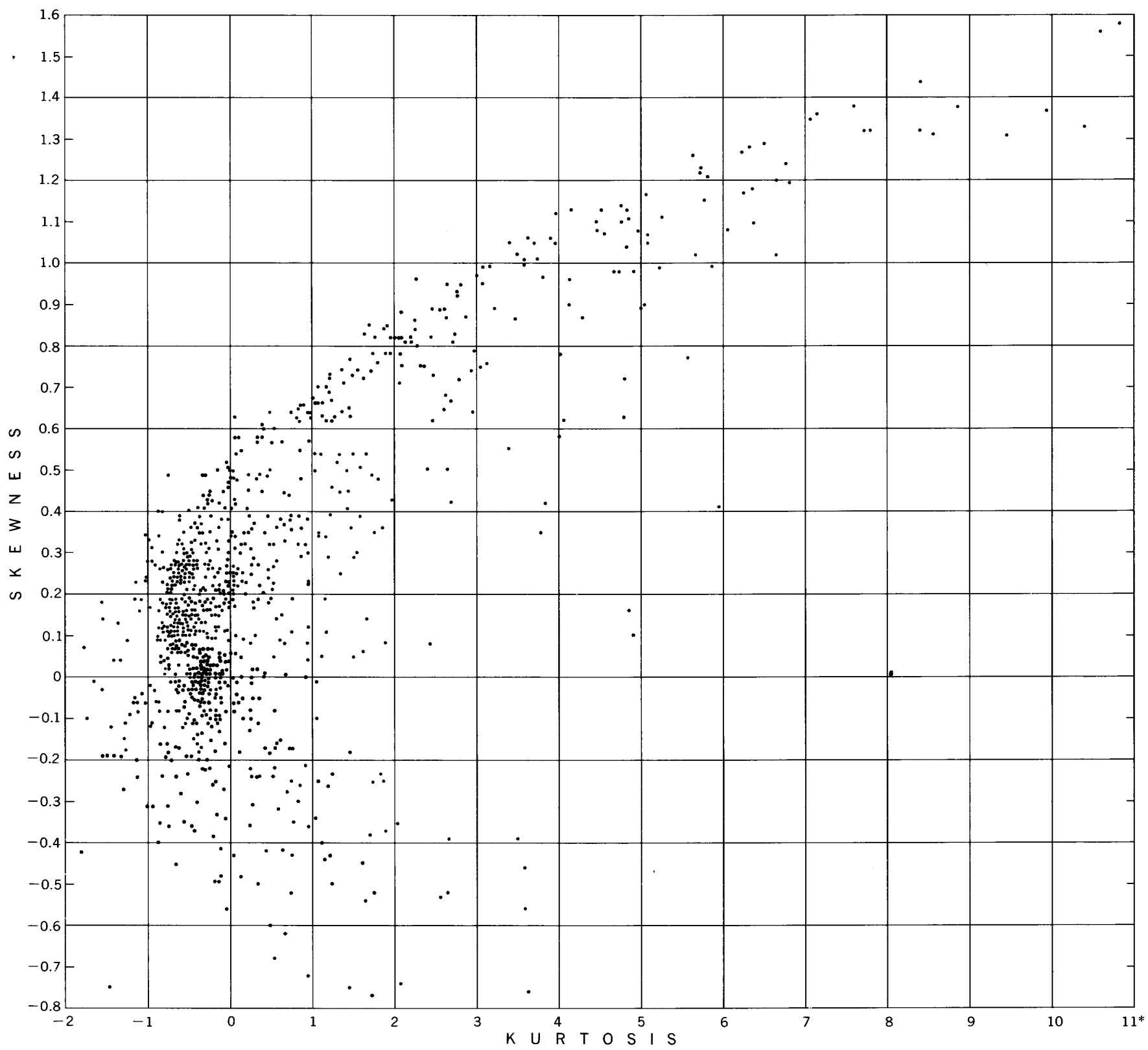

FIGURE 14.-Scatter plot of skewness versus kurtosis. Note broad recumbent U-shaped scatter of points. Four points having a kurtosis between 11 and 18.5 and a skewness between 1.2 and 1.9 lie beyond the limits of the figure. One point with a kurtosis of 1.4 and skewness of -0.88 lies beyond the lower edge of the diagram. 
tells very little about the environment, past or present, except that sorting of sediment needed to cause posiive kurtosis is possible in shallow marine areas where waves and tides are active.

CURVE SHAPE

Analysis of curve shape focuses attention on the normality (or nonnormality) of the size distribu- tion and also on the processes that have dispersed the grains. For this study the main transport agents appear to be ice, tractive currents, and pelagic suspensions. Doeglas (1946) and some of his students (van Andel and Postma, 1952; Koldewijn, 1958) were the first to analyze grain-size curve shape, followed by Fuller (1961, 1962), Spencer (1963),

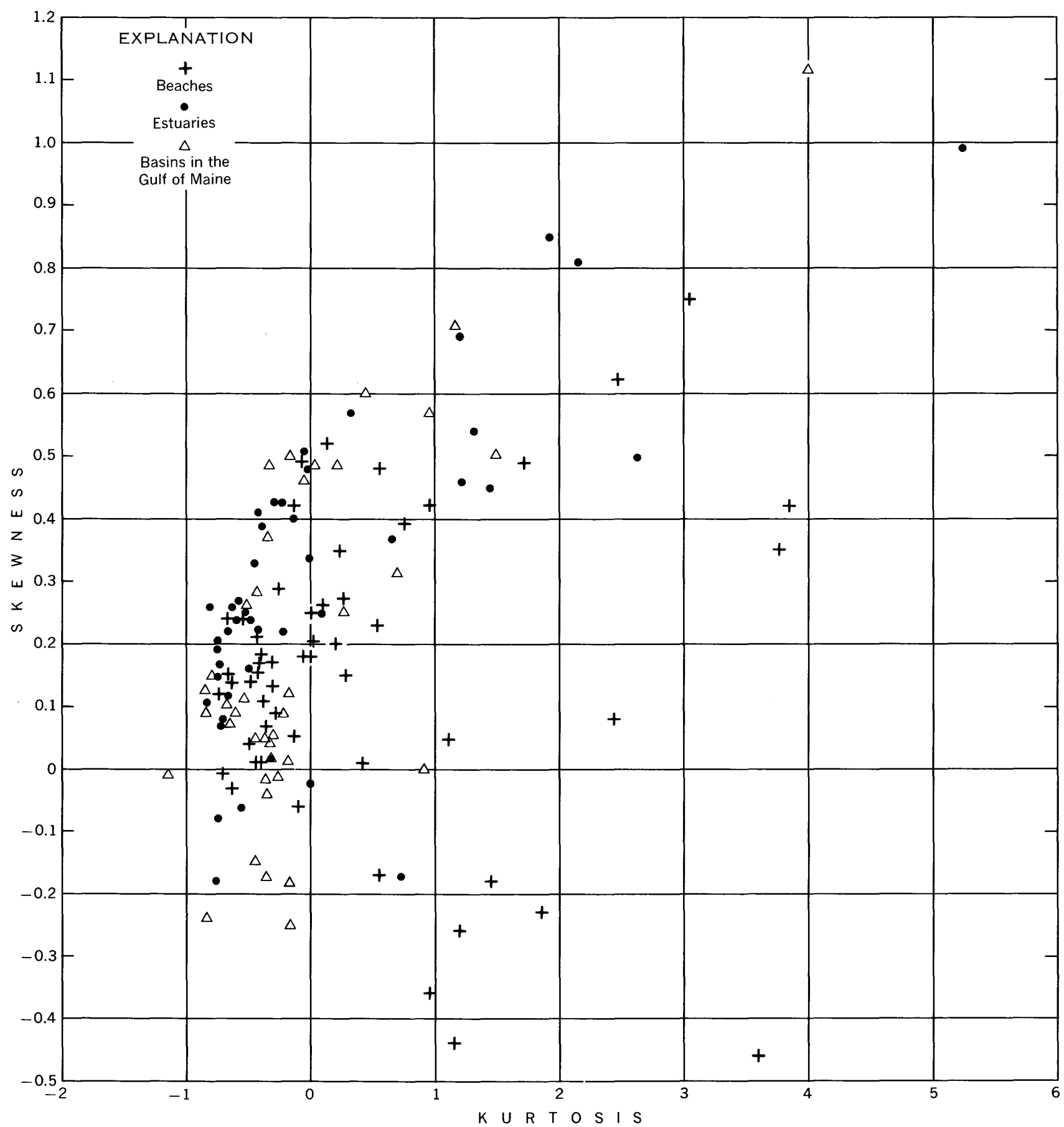

Figure 15.-Scatter plot of skewness versus kurtosis for samples from beaches, estuaries, and basins (Gulf of Maine). Note broad overlap of different milieus of deposition. 


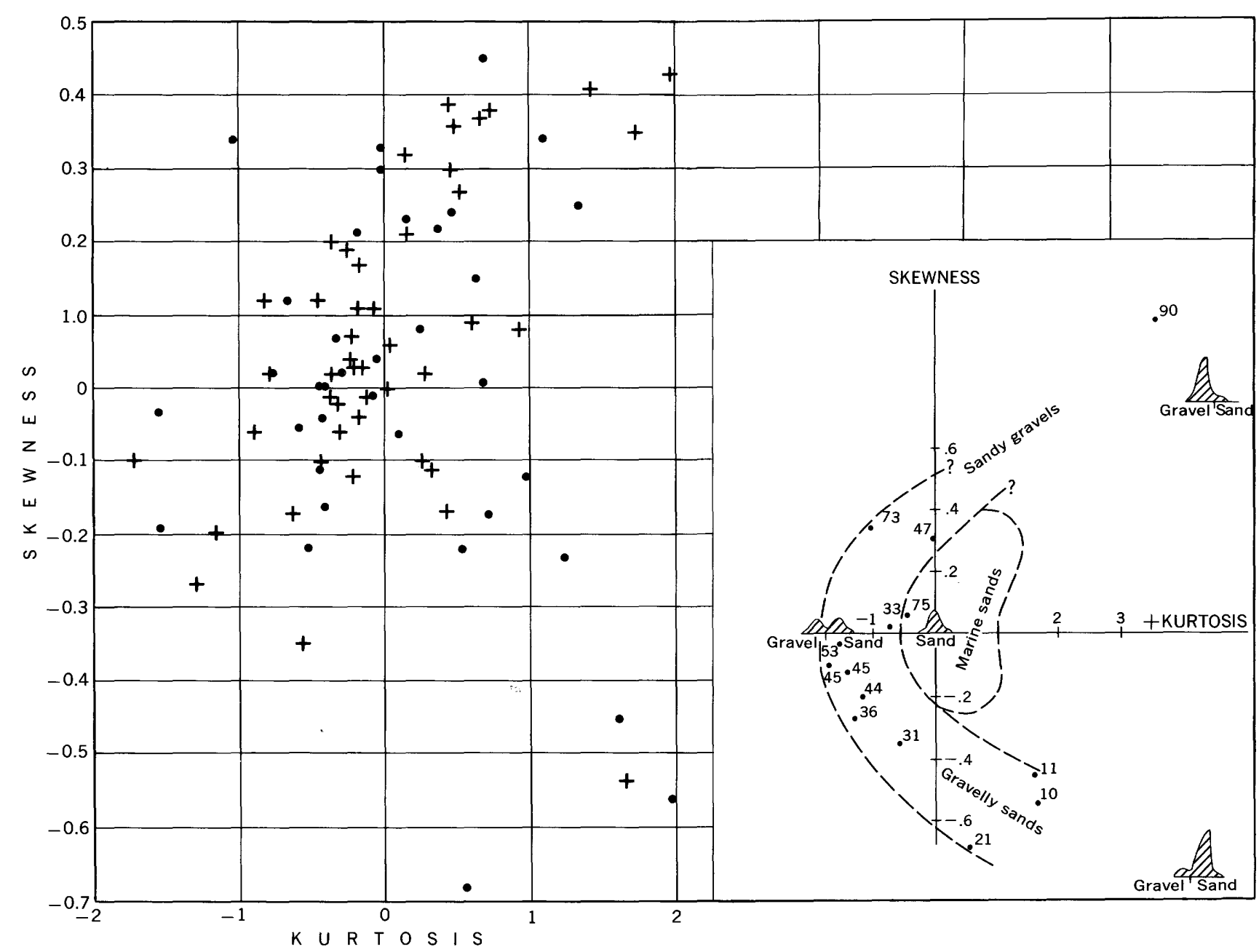

FIGURE 16.-Scatter plot of skewness versus kurtosis for nearshore sands. Samples are from sand ridge topography off New York and New Jersey (crosses) and the Nantucket Shoals-Georges Bank area (dots). Inset shows a plot of sandy gravels and gravelly sands alone. Values next to dots are the weight-percent gravel. Cross-hatched frequency curves are schematic representation to help visualize how mixing of sand and gravel can yield the scatter plot of kurtosis and skewness evident from the broad arc of points. Two points having a skewness of approximately 1 and a kurtosis of 3.5 and 4.5 lie beyond the limits of the figure.

and Visher 1967, 1969). Several authors have attributed distinctive shapes of the cumulative curves to different processes of sedimentation and to mixing of basic sediment populations. Eventually these processes have been correlated with different environments of deposition (beach, delta, dunes) by the same authors. Interpretation of the grain-size curve shape here is complicated by post-Pleistocene rise in sea level, and the incomplete adjustment of bottom sediment to present hydrologic conditions on the shelf.

Five main groupings of curves emerge from an examination of 563 size analyses (fig. 17 and pl. $4 D$ ) ; three types were normally distributed and two were nonnormal. The log-normal distribution is checked for by plotting the size analysis on probability paper to see if it plots as a straight line; line slopes show the degree of the sorting from good (steep slope) to poor (flat slope). Moreover, truncation or addition of selected size ranges of sediment can be seen by changes or steps in the slope of the cumulative curve; departure from log normalcy is indicated by the same change in slope. Most of the samples used in the figure were obtained with the large-volume Campbell grab bucket on board the $\mathrm{R} / \mathrm{V}$ Gosnold. Individual curves with a particular shape category display a wide lateral range (fig. 18 ), as shown by the wide standard deviation values for each size class (T-bars in fig. 17) and the wide fluctuation of some mean size values at the 

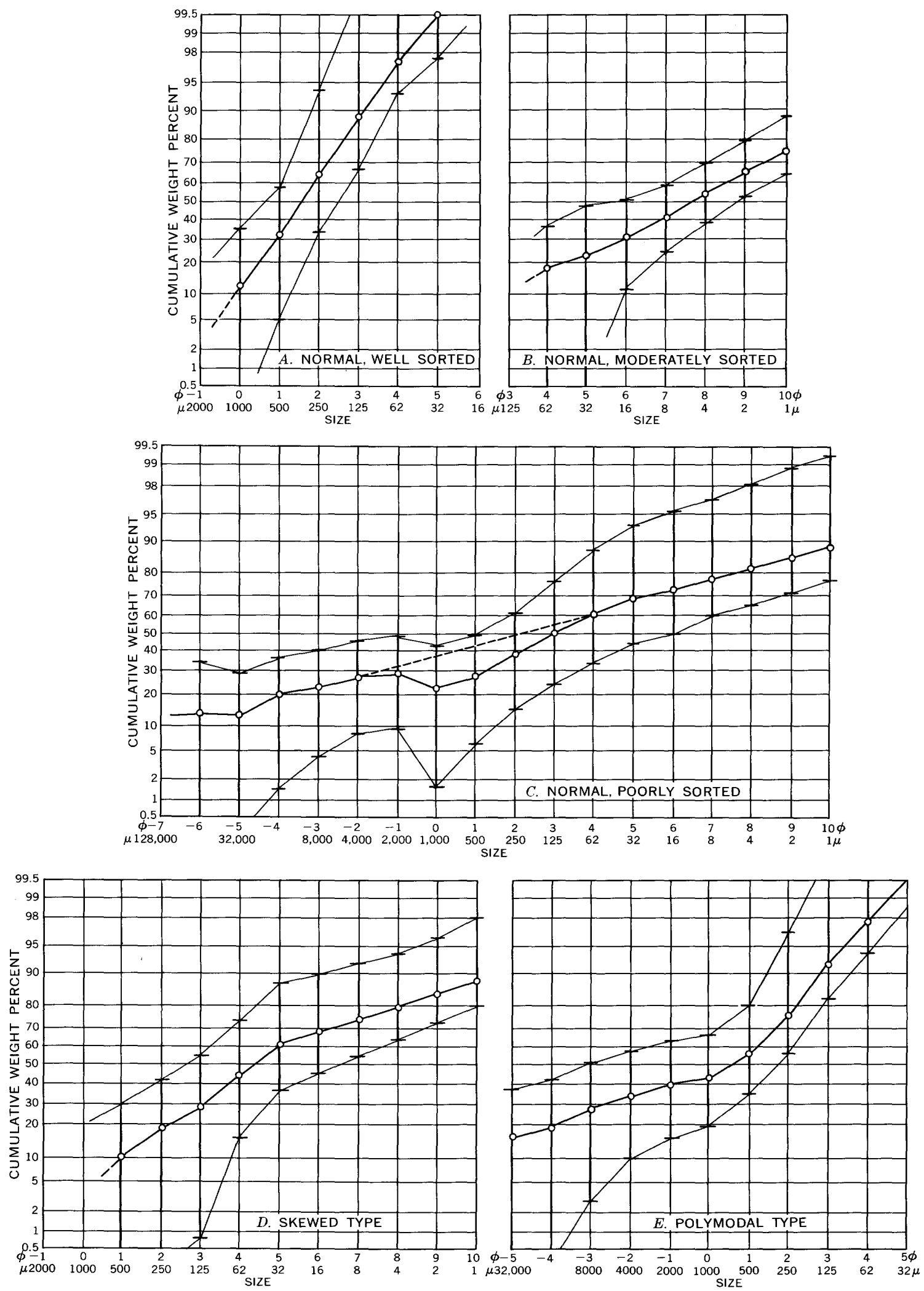

FIGURE 17.-Averaged cumulative grain-size distribution plotted on log probability paper and based on 563 size analyses. Five curve types are shown. Length of T-bars indicates the spread of values $(1 \sigma)$ for each size class. 
course end of the curve. The latter is due mainly to a paucity of values for the coarse end of the distribution. These fluctuations show up on the "normal, poorly sorted" curve (fig. $17 C$ ) where cumulative values actually drop. The reason for the dip can be seen in figure 22 where a flattening noted in some curves in the coarse sand range is evident and where some curves are just beginning their rise in this interval.
NORMAL TYPES

Three groups of analyses tend to be log normally distributed (fig. $17 A-C$ ); their areal pattern and sorting leads to the conclusion that current winnowing, ice, and gravity settling have been important agents in depositing the sediment. Much of the sand on the continental shelf (fig. 18 and pl. $4 D$ ) is log normally distributed and similar to tractive current deposits desoribed by Visher (1967), Spencer

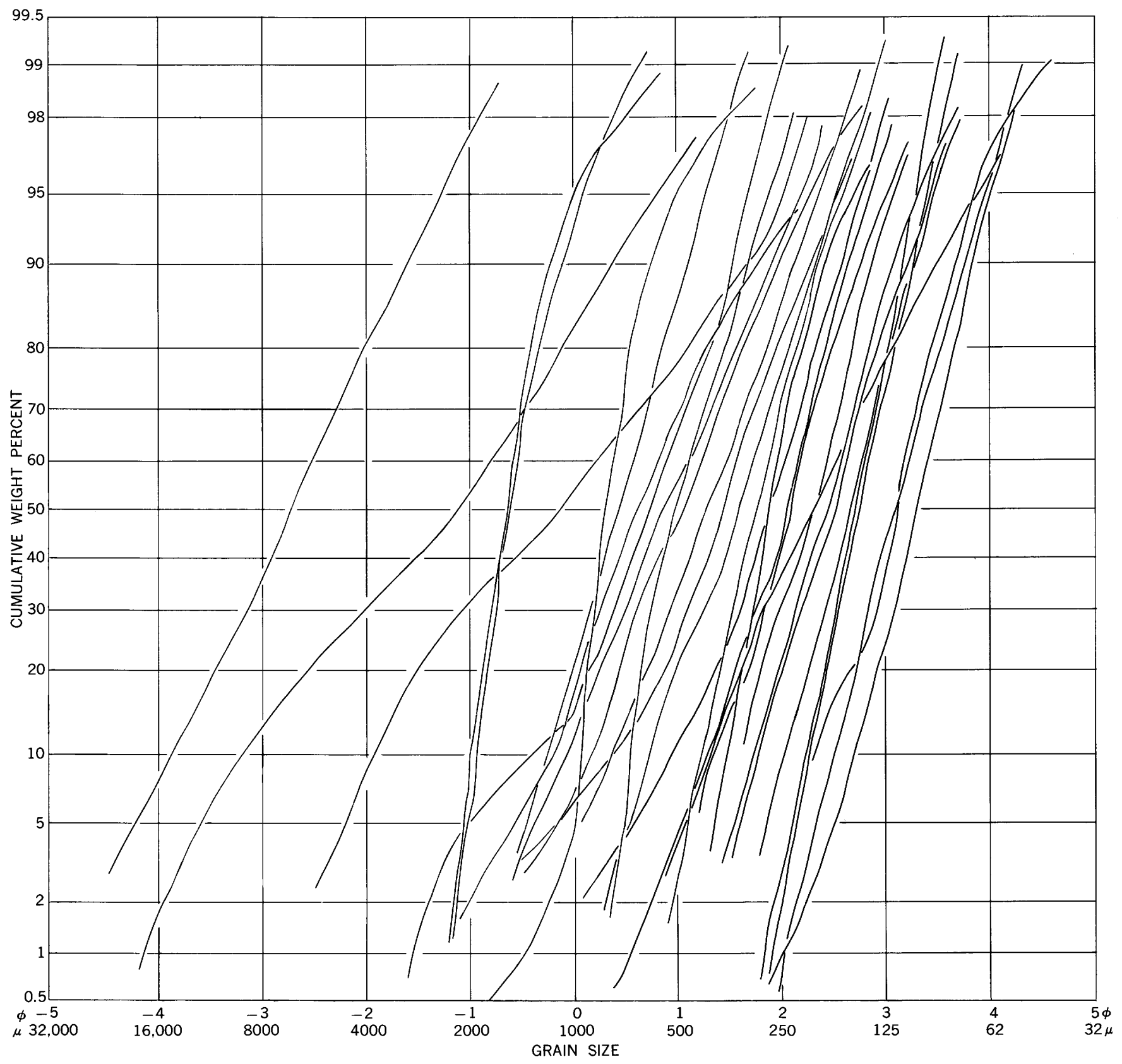

Figure 18.-Some representative cumulative grain-size curves of well-sorted sandy type. Note that distributions tend to be log normal. 
(1963), and Klovan (1966). Curves with this shape describe sediment that is extremely well sorted and can be found from the beach zone on out across areas of sand waves, sand shoals, and tidal ridges to the outer shelf. Generally, silt and gravel are absent, or if present, they are minor and restricted to the size range immediately adjacent to sand. The samples with this curve shape most closely fit what Klovan (1966) has described as "surf energy" deposits or "current energy" deposits; some curves (fig. 18) may have a tail of fine sediment in with the sand, similar to Klovan's current-transported sediment. Most beach sands adjacent to the Coastal Plain of New Jersey and New York plot as a steeply inclined straight line, identical to Klovan's surf-deposited material. Again there is a source factor in beach-sand curve shape. Sands from coastal New England, where local bedrock and glacial debris supply the detritus, are more irregular, and they may have a less well sorted gravel fraction. Not only is there a multiplicity of sources for the sand, but the modes of transport are different depending in part on the size fraction (Moss, 1963). Hence, much of the gravel can be seen to move by rolling and sliding, and the sand, by saltation or in suspension. Studies by Moss (1962, 1963), Fuller (1961), and Visher $(1967,1969)$ stress the importance of selective processes within a particular environment such as a beach, on the grain-size curve shape.

The second type of log normally distributed bottom sediment is mainly silt and clay (pl. 1 and figs. $17 B, 19)$. It shows a larger range in grain size (less slope to curve) than the first type and also shows gradation with the skewed curve type (fig. 17D). Most analyses in this group are from areas of pelagic sedimentation such as the continental rise, western basins of the Gulf of Maine, and a few sheltered sounds and bays (pl. 4D). Though most of the sediment is clay or silt, the analyses can have a large sand component (pl. $4 D$ ) as an integral part of the size distribution. The log-normal pattern extends from sand (sized by the settling tube) down into silt and clay analyzed by pipetting. Despite the difference in methods of analysis of the two fractions, the transition is smooth. The lack of a break between the sand and silt populations suggests that

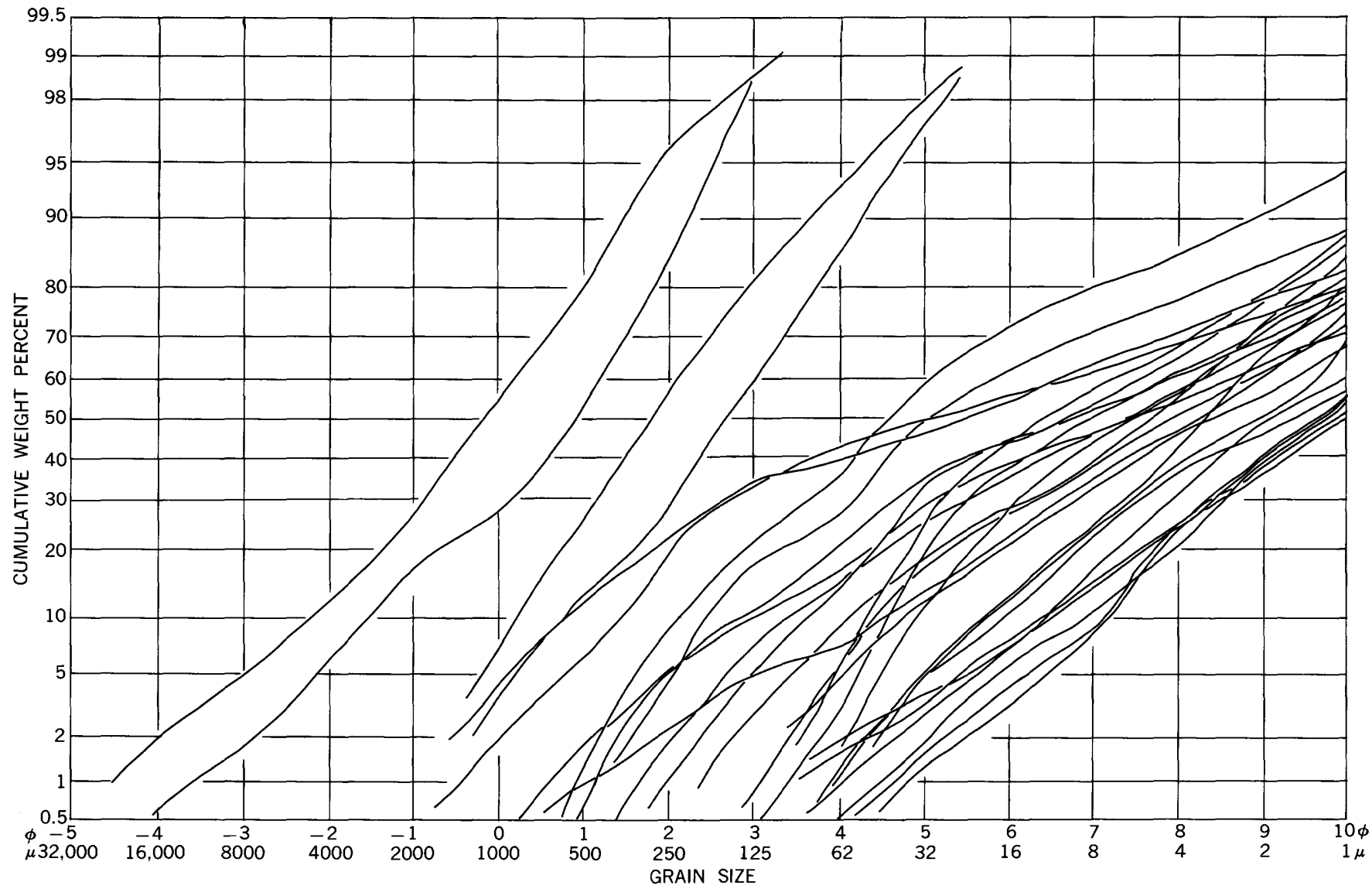

FIGURE 19.-Some representative cumulative grain-size curves of moderately sorted silty type. Note that the distribution tends to be $\log$ normal. 
the transport processes affected both components and deposited them at about the same time.

Size curves with a similar shape have been reported for fine-grained gravity-settled deposits in Barataria Bay, La., by Krumbein and Aberdeen (1937). Klovan (1966) emphasized the settling process for these deposits though Spencer thought the distribution reflected mainly a basic "clay" population. Support for Spencer's basic clay-silt population has been shown. Coincidently, gravity settling of fine detritus in suspension probably is a contributing process to deposition offshore.

The Gulf of Maine is veneered by till-like mixtures, particularly between the basins; many of these mixtures of gravel, sand, silt, and clay plot as nearly straight lines (fig. 20) with a low slope. Other curves bridge a similar size range but show a paucity of sediment in the coarse- to medium-sand interval $(1-1 / 8 \mathrm{~mm})$. Still others are mixtures only of sand, silt, and clay but have a similar slope to the mixtures with gravel.

The dip in many of the cumulative size distributions could be interpreted as a mixing of the gravel population with another of sand, silt, and clay. However, the similar slope of many of such curves on either side of the coarse- to medium-sand interval leads me to suspect that they are part of a single population from which sand has been winnowed. The dip happens to overlap the interval of grain diameters most easily removed by erosive currents during transport of a sediment bedload (Sundborg, 1956, fig. 23). Though some samples with this curve inflection are close to others without it, there is a limited tendency for samples with this inflection to have been collected in shallower water than those without it. Average depth is $131 \mathrm{~m}$ for samples without an inflection, $103 \mathrm{~m}$ for those samples with an inflection in the curve; averages are based on samples collected by the large-volume Campbell grab bucket from the Gulf of Maine. Depths for the two subtypes of curves overlap, but the MannWhitney $U$ test suggests a significant difference between the two groups of depths at the 10-percent significance level.

Poorly sorted normal curves (pl. $4 D$ ) are restricted almost entirely to the Gulf of Maine-an area whose topography appears to have been shaped or modified by Pleistocene glaciation. Curves are similar to some glacial tills (Krumbein and Pettijohn, 1938, fig. 102; Horberg and Potter, 1955;

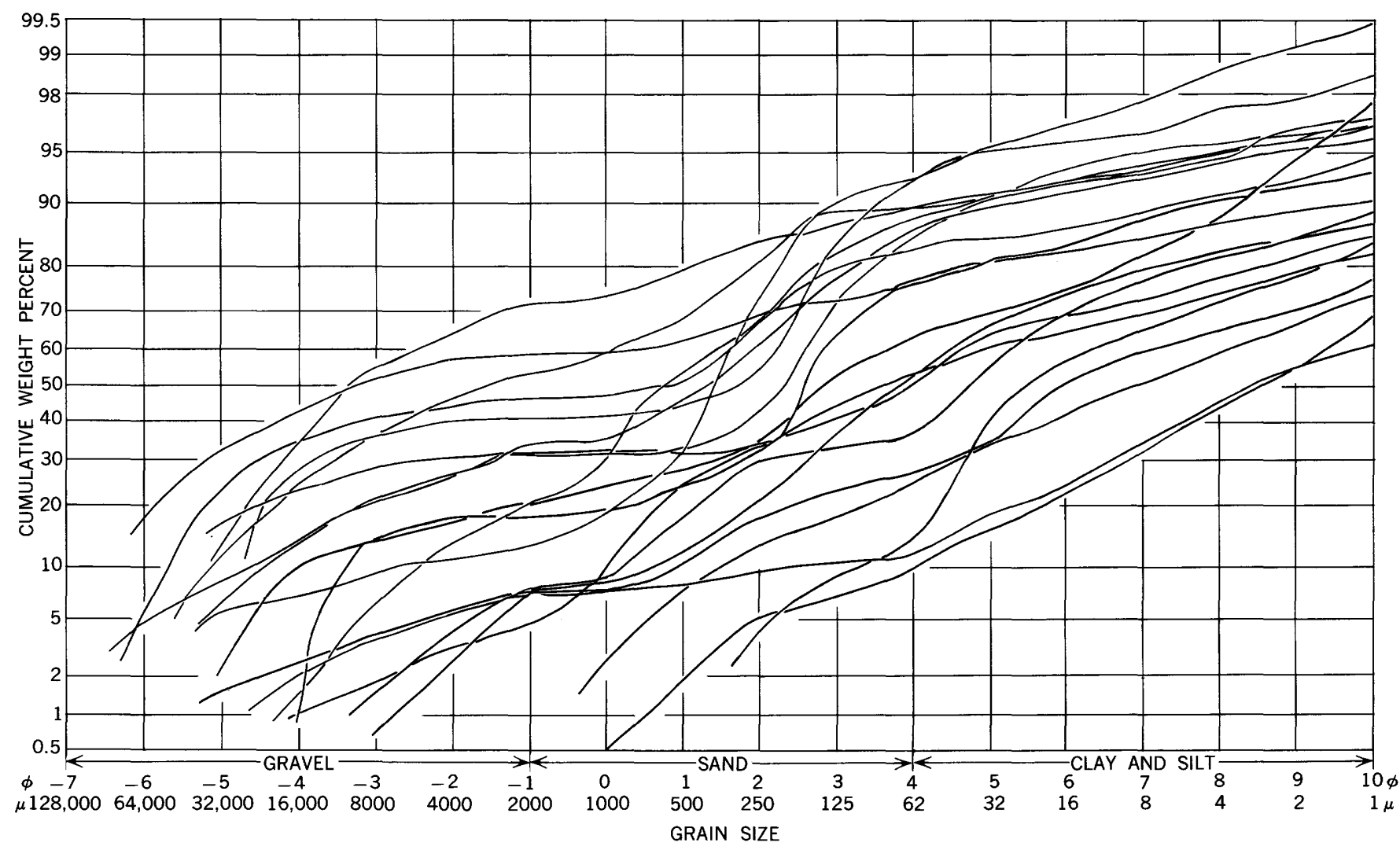

Figure 20.-Some representative cumulative grain-size curves of poorly sorted gravelly type sediment. Distributions have a wide range in grain size and some are log normal. 
Linell and Shea, 1960) in the midwestern United States and New England, though as noted by Flint (1957, p. 111-112) tills can have a wide range in grain size. The intimate association of finer detritus with the coarse material rather than an infilling of finer sediment around a gravelly framework, suggests that the two fractions were deposited together and that the agent of transport was incapable of sorting its load.

NONNORMAL TYPES

Two groups of size curves are not distributed in a log-normal fashion, and together they constitute about 39 percent of the size curves examined for shape. One type is broadly skewed and spans the area between current-winnowed shelf and bank sand and pelagic silty clays. The other type, a polymodal mixture of sand and gravel is associated with reworked glacial outwash and relict fluvial deposits.

As shown in figures 17 and 21, many sediments are broadly skewed toward the coarse end of the size distribution-a tail of fine-grained sediment. Hence, distribution of these skewed sediments ( $\mathrm{pl}$. $4 D$ ) broadly overlaps positive values of skewness, particularly above 0.5. Most of the skewed sediments are on the continental slope, the continental shelf south of Massachusetts and Rhode Island, around some basins in the Gulf of Maine, basins of the

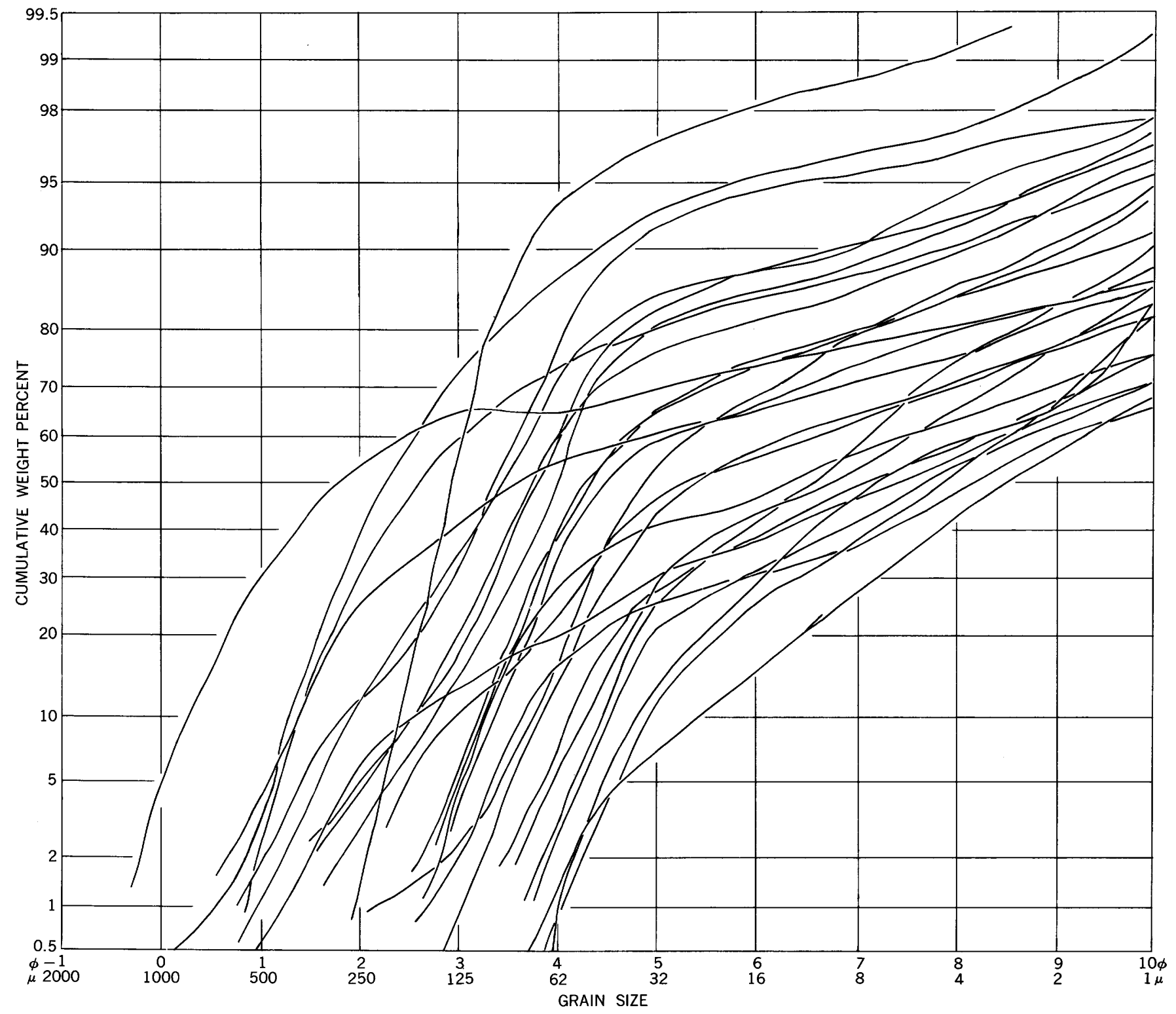

FIGURE 21.- Some representative grain-size curves of skewed type. Notice the decided break in curves, from well-sorted sands to moderately sorted silt and clay fractions. 
Scotian Shelf, and adjacent to the Maine coast. They vary widely from silty sands to clayey silts and mixtures of sand, silt, and clay. Most show moderate sorting (pl. 4A) though a few are poorly sorted.

The curves (fig. 21) basically appear to be of two main components in varying amounts; (1) sand and (2) silt plus clay. These two fractions are reflected in the two main segments of the curve, a coarse better sorted sandy part and the finer grained more poorly sorted silty and clayey part. The curves are similar to those obtained by Spencer (1963, fig. 6) by mixing equal amounts of sand and silty clay. Many distributions have a slight dip in the transition zone similar to that shown by Spencer. The break ranges from $1 / 4$ down to $1 / 32 \mathrm{~mm}$, depending on the proportion of each component.
Curves with a similar shape have been noted in shallow waters of Barataria Bay, La. (Klovan, 1966), and ascribed by him to transport by bottom currents. Visher $(1965,1967)$ found grain-size curves with a similar shape in river sediments and ascribed the shape to contribution by two processes, tractive currents and gravity settling of fine detritus out of suspension. Both type processes might operate in a fluctuating-current regime, as described by Sundborg (1956) in the Klarälven River, Sweden, and by Duane's (1964) study of Pamlico Sound where tails of fine suspended sediment were tied into the efficacy of the wind and waves to rework the open-sound sediments.

About 11 percent of the analyses are polymodal mixtures of sand and gravel (figs. $17 E$ and 22). The gravel seems to be the more poorly sorted of



FIGURE 22.-Some representative cumulative grain-size curves of sediment having a polymodal distribution. Note that curves are divided into two main fractions (sand and gravel) with a paucity of detritus in between (curve flattening). 
the two components, and little sediment finer than sand is present. The flattening curve slope is in the very coarse sand and granule interval. As noted in an earlier section, this same interval is deficient in the occurrence of size modes (fig. 8).

Most of the polymodal sediment is in shoal areas like the patchy border south of the Gulf of Maine and isolated areas south of Long Island and east of New Jersey (pl. $4 D$ ). Banks within the gulf, such as Fippennies Ledge, are veneered by a lag of glacial erratics associated with finer gravel and sand. A comparison of plate $4 D$ with plate 1 and figure 7 shows the coincidence of this type of size distribution with mixtures of sand and gravel, particularly the latter. Sediment with this curve shape tends to be moderately sorted (1.5-3.0), and skewness is variable depending on the relative proportions of sand and gravel.

Bimodal distributions of this type have been described from both beach and river deposits and have been discussed by Schlee and Pratt (1970). The coincidence of this group of analyses with off- shore extension of moraine deposits (Pratt and Schlee, 1969) near Long Island and east of Cape Cod suggest a relict glacial source of some detritus, in part modified by fluvial transport during dispersal in the Pleistocene or by nearshore currents now and during the Holocene rise in sea level.

In a few samples (3.6 percent), grain-size curves do not appear to fit any of the distinctive types (fig. 23). Some are well-sorted sand but have a tail of coarse detritus; as such they resemble tractive current deposits that have a noticeable load of grains moved by rolling or sliding (Visher, 1969, fig. 4). Others show a marked deficiency of grains in a certain size interval, almost as if there were selective winnowing of detritus from one population or an incomplete mixing of two basic populations.

In summary, a plot of grain-size distributions on log-probability paper shows that almost all samples fit one of five types-three log-normal types, a skewed type, and a polymodal type. Moreover, a map showing distribution of these five types (pl. $4 D$ ) indicates that well-sorted normally distributed

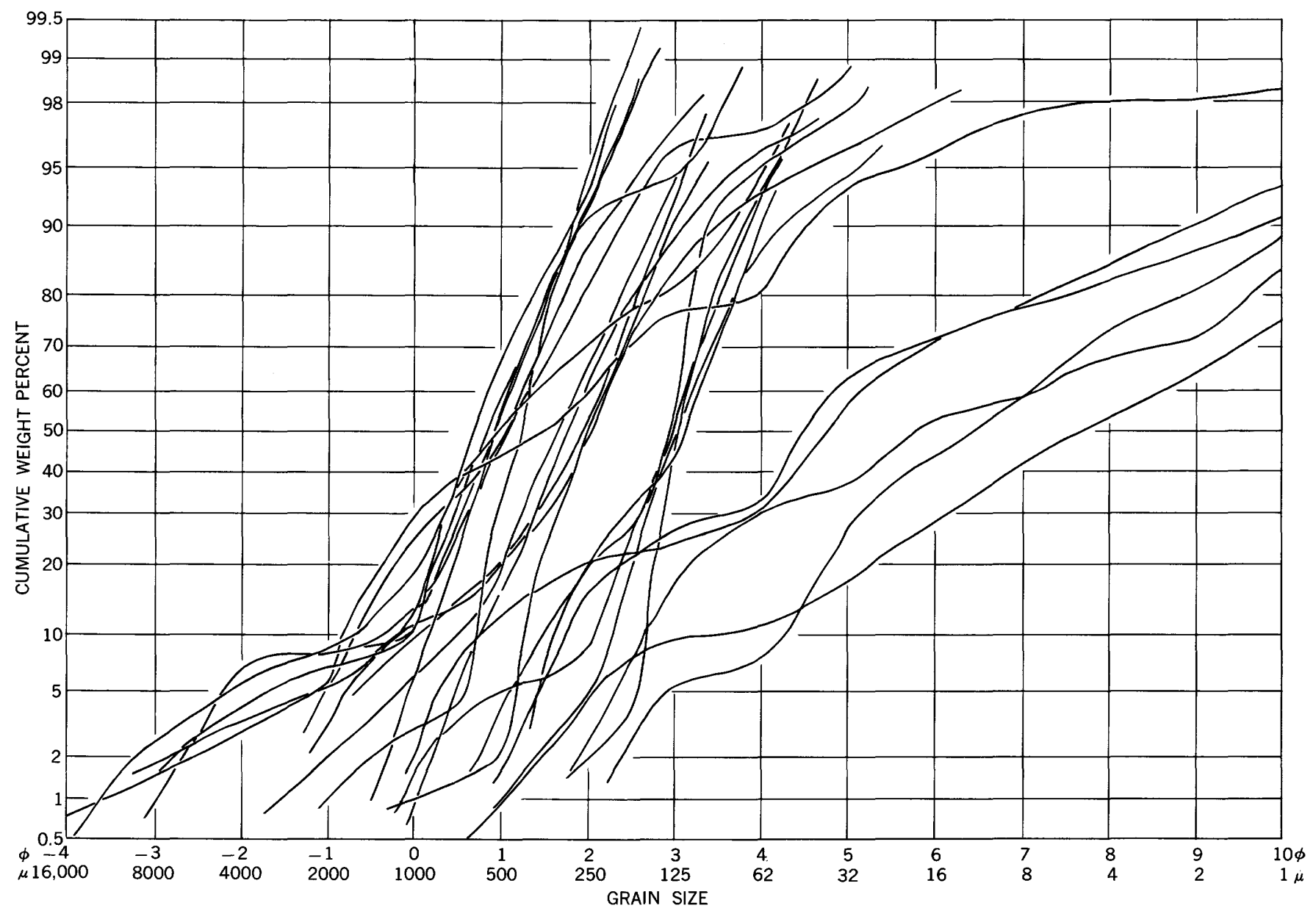

FIGURE 23.-Some examples of cumulative grain-size curves that do not appear to fit in any of the five curve shapes. 
sands are on the shelf, till-like mixtures of sand, gravel, silt, and clay are in the Gulf of Maine, and moderately sorted pelagic silty clays are on the continental rise and some basins in the Gulf of Maine. Skewed distributions are mainly on the continental slope and the shelf south of New England and border a few basins in the Gulf of Maine. Polymodal sandy gravel and gravelly sand are on shoals associated with glacial deposits.

\section{PASSEGA C-M DIAGRAMS}

In an effort to relate grain-size distributions more directly to the processes that may have deposited the sediment, the different curve shapes were plotted on C-M diagrams (Passega, 1957, 1964). The ap- proach grew out of a summer fellowship project sponsored by the Woods Hole Oceanographic Institution and carried out by Mrs. Nancy Sideras in 1966. Passega found that by plotting the median grain size (M) versus the grain size of the coarsest 1 percent of the distribution (C), he was able to separate fields dominated by different agents of sediment transport, that is, tractive currents, turbidity currents, and pelagic suspension (fig. 24). $\mathrm{He}$ was able to further subdivide tractive currents into graded suspensions, uniform suspensions, and rolling-sliding-saltation transport. 'The choice of these particular parameters attempts to define the spread of the coarse half of the size distribution in

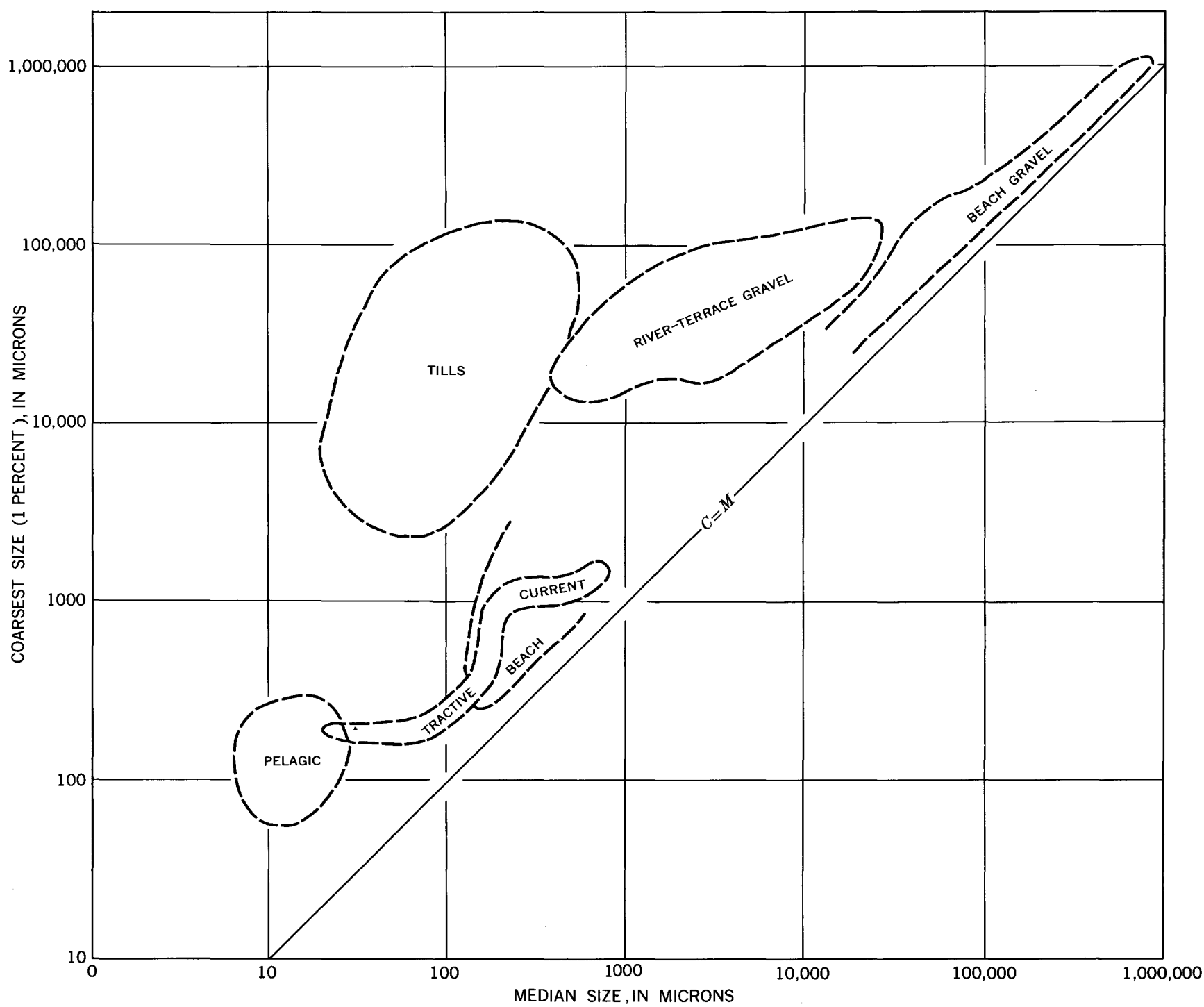

Figure 24.-Passega (1957, 1964) C-M diagrams for several hundred sediment samples from different kinds of deposits. Pelagic, tractive current, and beach samples (Emery, 1955) are from modern environments. River-terrace gravel (Potter, 1955; Schlee, 1957) and till samples (Udden, 1914; Wentworth, 1932; Krumbein, 1933; unpub. analyses supplied by C. Koteff) are from Quaternary or upper Tertiary deposits. Lines bound fields where most of the C-M values fall. 
order to gain an estimate of the competency of the depositing agent. Though some overlap does exist, Passega was able to show that sediments deposited by different agents occupied different parts of the diagram. Most of his analyses were for sandy or silty sediment, whereas this study includes gravelly sediment and glacial tills (fig. 28). In addition to Passega's original data, fluvial terrace gravels from western Kentucky (Potter, 1955) and southern Maryland (Schlee, 1957) have been plotted along with beach gravel from southern California (Emery, 1955). In addition, till analyses are included from Krumbein (1933), Wentworth (1932), and Udden (1914), plus several till analyses from New England, kindly supplied the author by Carl Koteff of the U.S. Geological Survey.
The diagram (fig. 24) shows several obvious fields created by different depositional processes. Tractivecurrent deposits, be they beach gravel or river sand, are close to the $\mathrm{C}=\mathrm{M}$ line. Winnowing and sorting narrowly restricts grain-size range; therefore, the median and coarsest fragment are close to the same size. Passega (1957, fig. 2) found that tractivecurrent deposits tail out into the sediment carried in suspension by the river, a fraction that can settle out in sloughs or as overbank deposits. The fine fraction of tractive-current deposition also shows a transition into quiet-water gravity-settled offshore silt and clay. Most of his analyses for pelagic deposits are from the Gulf of Venezuela and Lake Maracaibo (Passega, 1957, fig. 6). Their sorting is poorer to judge by the widened field and its dis-

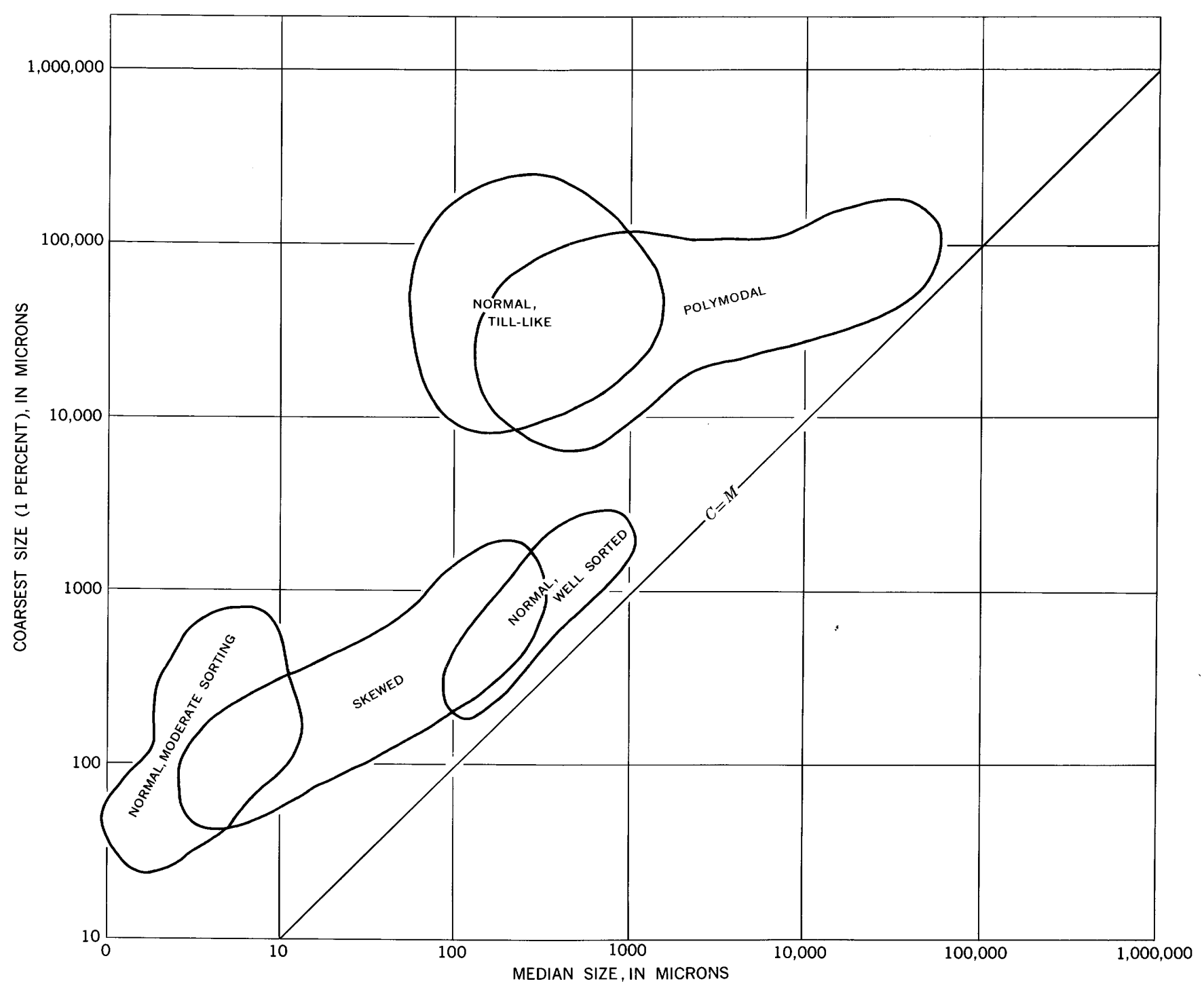

Figure 25.-C-M diagram of the fields for the five curve-shape types. 
tance from the $\mathrm{C}=\mathrm{M}$ line. Beach and river gravels show a separation mainly because the river deposits have an interstitial sand framework. Probably this results from the several modes of tractive transport noted by Passega for river deposits, whereas beach gravels are sized mainly by rolling and saltation. Turbulence is sufficient to move the sand out. In the river gravels, interstitial volume calculations suggest that the sand and gravel are deposited simultaneously (Plumley, 1948, p. 544), and hence the divergence of $\mathrm{C}$ and $\mathrm{M}$. The most extreme divergence of $\mathrm{C}$ and $\mathrm{M}$ is in the till (fig. 24). Ice has the ability to transport the broadest range in size of rock debris. Yet as has been noted, till can be quite variable in size distribution, depending on what is available for transport. This variability can be seen in figure 24 by the broad area of the field; characteristically poor sorting is evident by the distance from the $\mathrm{C}=\mathrm{M}$ line.

A C-M plot was made of the different curve shapes (fig. 25) in order to relate them to deposits with a known origin. The field of well-sorted normally distributed sand broadly parallels the $\mathrm{C}=\mathrm{M}$ line and falls close to it. Skewed distributions bridge a field between the well-sorted sand and pelagic finegrained sediment, just as they do areally. Silty clays from the basins of the Gulf of Maine and upper continental rise occupy a fairly wide field, well away from the $\mathrm{C}=\mathrm{M}$ line. At the coarse end of the C-M diagram, till-like sediment is in a widely dis-

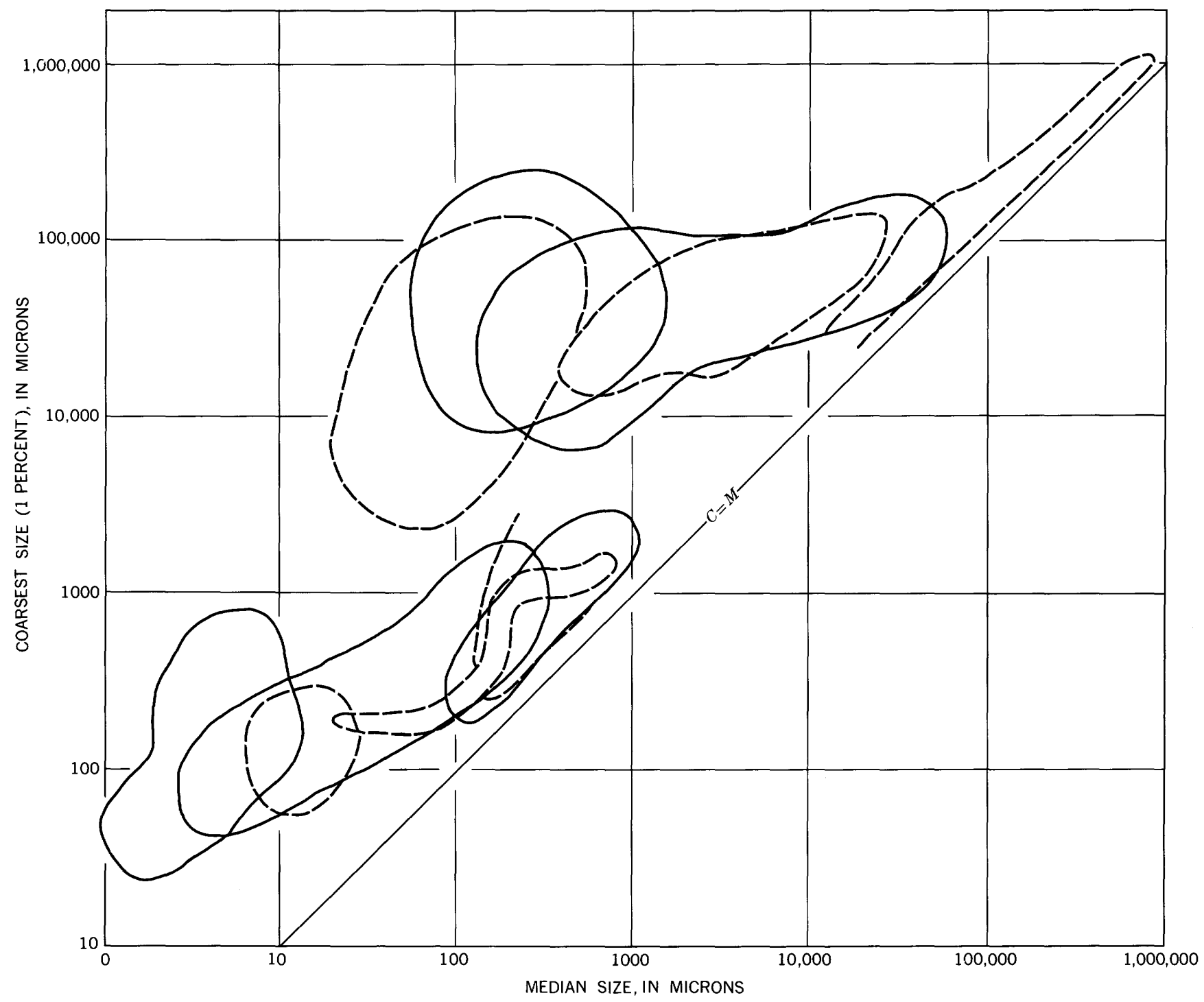

Figure 26.-Superposition of figures 24 and 25 to show which continental-margin sediment types might have been deposited by which agents. Broad overlap of fields is taken to indicate an association of that type of sediment with deposits originating by a particular agent. Dashed boundaries are from figure 24 and solid lines are from figure 25. 
persed field, farthest away from the $\mathrm{C}=\mathrm{M}$ line. Polymodal gravelly sand and sandy gravel also have a broad field which approaches the $\mathrm{C}=\mathrm{M}$ line in the gravel range (for $C$ and $M$ values).

The broad areas of overlap shown by superposition of figures 24 and 25 (fig. 26) lends support to sediment movement by tractive currents, ice, and suspension. Tractive-current beach and river sands coincide with well-sorted shelf sand. Less overlap occurs for quiet-water pelagic sediment and moderately sorted silts and clays from the Gulf of Maine basins and continental rise. Skewed sediments overlap both suspension deposits and tractive-current deposits, indicating again that perhaps both of these processes are effective in shaping the size distribution. Polymodal grain-size curves coincide with those of river-terrace gravels, some beach gravels, and some till. The overlaps suggest a tractivecurrent agent which allowed for transport of sand and gravel, plus winnowing of the finer detritus. The overlap onto the till field may be due to reworking of these deposits by marine currents, as noted by Schlee and Pratt (1970).

In summary, C-M diagrams indicate that tractive currents have dispersed sand on the shelf; in deeper areas, much sediment appears to have settled out of suspension. A composite of these two processes may have deposited skewed silts and fine-grained sands. For gravelly sediment (high $\mathrm{C}$ values), traction transport is indicated for polymodal sediment types and glacial transport for the poorly sorted sediment debris from the Gulf of Maine.

\section{SEDIMENT GEOMETRY}

The third dimension of the sediment cover has been mentioned only slightly, yet changes in sediment with depth and laterally, bear on the origin of the sediment and the most recent history of the continental margin. Main sources of this type data are echo-sounding records, shallow continuous seismic profiles, and $\log$ s of a few shallow drill holes. The logs are from Texas Tower sites on Georges Bank, Nantucket Shoals, and the shelf south of Long Island, plus sites in the New York Bight for Coast Guard light towers.

Echo-sounding profiles (fig. 27) reveal several different types of bottom traces that relate to glaciation, subsequent pelagic sedimentation, and reworking of shoal areas by bottom currents. As first noticed by Murray (1947), these records show a double bottom (fig. 27 A) caused by an acoustically translucent sediment layer, covering an acoustically opaque sediment or rock to a depth of several meters.
Samples taken along the profile shown in figure $27 \mathrm{~A}$ indicate that the upper material is a silty clay and the acoustically opaque sediment is a variety of types including till-like gravel, sand, and sandy silt. As well described by King (1967, 1969), echo-sounding records can provide (1) an idea of the different types of sediment along the profile track and (2) stratigraphic relations between different types of sediments. King was able to correlate his records with five sediment types: (1) clay, (2) silt, (3) glacial till, (4) sand, and (5) sand and gravel. The last two types were found by King on the Scotian Shelf closely associated with a submarine terrace at 110-210 meters. On the echo-sounding records here, several of King's types show up. The acoustically transparent material in figure $27 \mathrm{~A}$ is silty clay or clay; the rolling hummocky opaque reflector is a mixture of sand, silt, gravel, and clay. Some of this material may be glacial debris and some is probably talus from nearby outcrops mixed with finer grained sediment. Still other records (fig. 27B) show layered reflectors beneath the silty clay. Some of this stratified sediment may represent glaciofluvial sand or clay that was dumped into ponded areas as ice withdrew from the area. On the flanks of several banks in the Gulf of Maine, the echogram (fig. 27C) shows a smooth to slightly hummocky bottom and some penetration of the sediment, to judge by the increased width of the bottom trace; the sediment associated with the trace is texturally between the silty clay of the basins and the gravelly sand of ledges, namely, a silty sand, a sandy silt, or a sediment of subequal amounts of sand, silt, and clay. Sand and winnowed sandy gravel show up as a smooth record with little evidence of penetration (fig. 27D). Some of the sand may be heaped into sand waves (fig. $27 E$ ), but most sand and gravel are recorded on a nearly flat bottom with a clean trace.

Bedrock probably crops out in a few areas such as the shelf immediately off Nova Scotia, Cashes Ledge, and Jeffreys Ledge. Echo-sounding records reveal (fig. $27 F$ ) a very hard bottom (no penetration, no ponded sediment pockets) and a relief of several meters or tens of meters over horizontal distances of only a few hundred meters or less. The coarseness of gravel associated with these areas, and the fact that granite outcrops have been sampled on Cashes Ledge, indicate that these areas are probably bedrock, lightly veneered by rock debris. Seismic profiles (Uchupi, 1966a, c) reveal the bedrock very close to the sea floor in this area. Distinguishing bedrock from glacial deposits is difficult because the two are probably associated, as on Cashes Ledge. A more hummocky profile and a lower relief have been used 

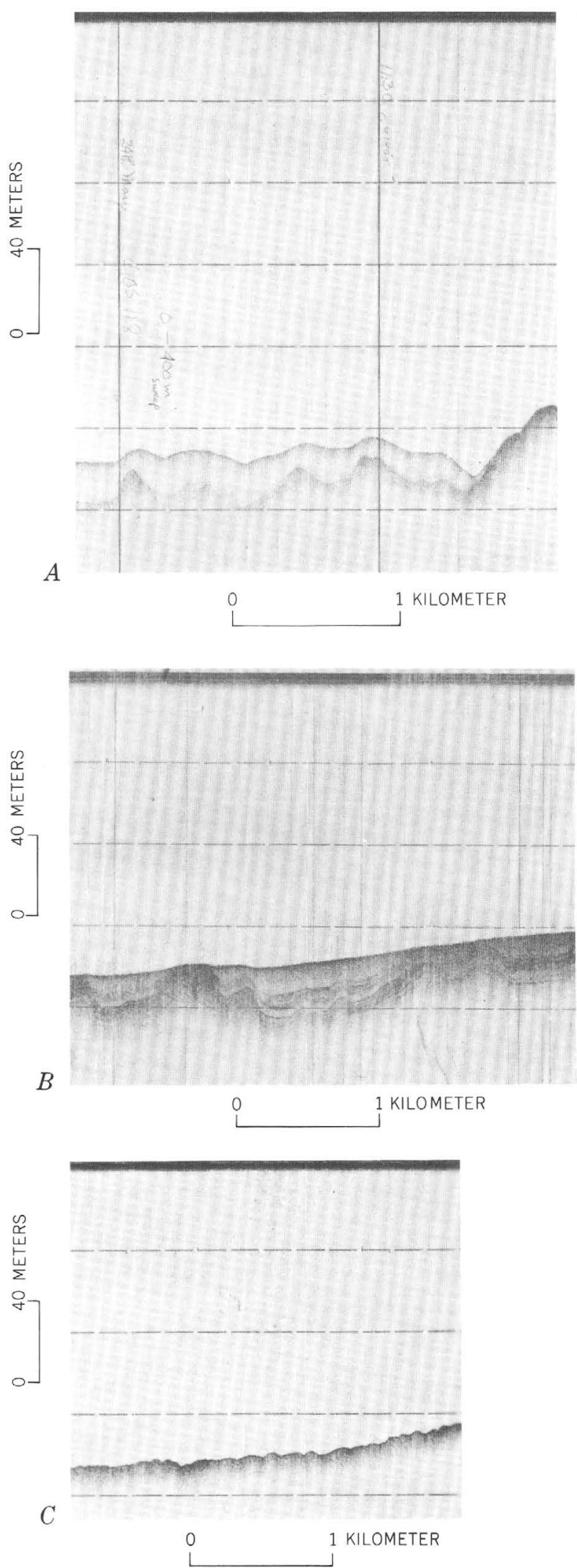

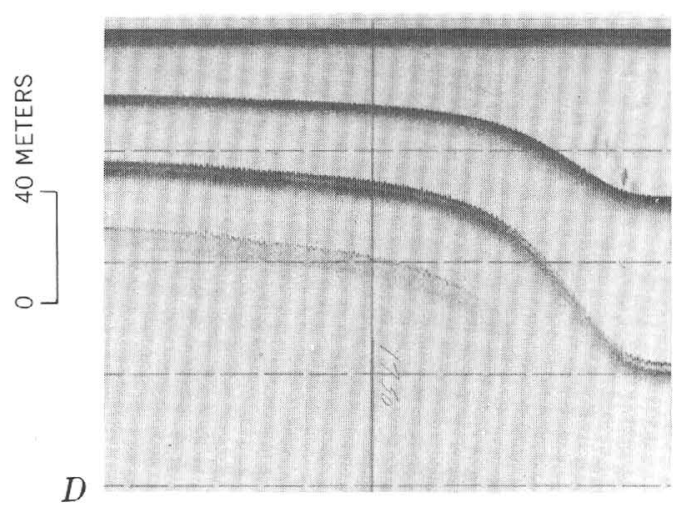
$1 / 4$ KILOMETER
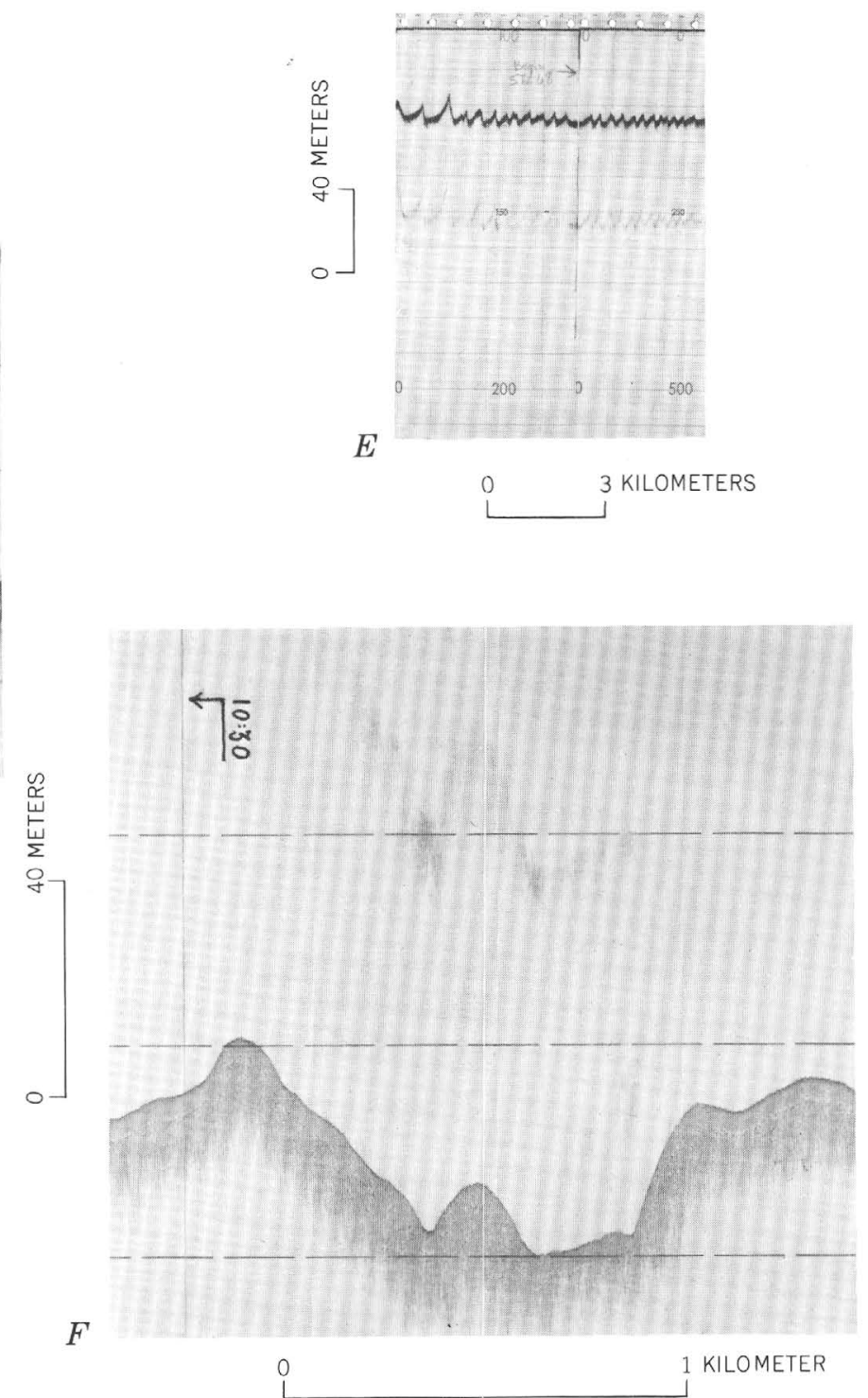

Figure 27.-Echo-sounding traces to show six distinctive types of sea floor. Length of profiles ranges from less than 1 to $3 \mathrm{~km}$. 
to distinguish presumed glacial deposits from the bedrock sea floor.

Examination of approximately $3,300 \mathrm{~km}$ of echosounding records (pl. 5) made in the Gulf of Maine and Georges Bank shows a good correlation of bottom trace, the sediment type, and physiography (pl. $6)$. About 63 percent of the tracks were run by the Bureau of Commercial Fisheries aboard Albatross III and were made available by $\mathrm{R}$. W. Wigley. The remainder were taken on various cruises of the $\mathrm{R} / \mathrm{V}$ Gosnold. The figure shows that most of the hard flat bottom is on the sandy southern part of Georges Bank and that it extends as an arc around the northern flank; banks in the Gulf of Maine and floor of Georges Basin also show a similar trace. Rippledshoal sea-floor traces show up in gravelly sand shoals of northern Georges Bank, Great South Channel, and Nantucket Shoals. The region of the double bottom is mainly in basins and in the broad divides between basins. It incompletely veneers older deposits as a discontinuous covering a few meters to several tens of meters thick. The transparent layer has a relief of its own, in part following the buried topography; it cannot be interpreted as a soupy ponded sediment tending to fill in the lowest areas of the sea floor. In Jordan Basin for example, the layer is mainly in the southwestern part of the basin, and not in the deepest part. To the northeast, the double-bottom trace is lost and is replaced by a mushy single trace of the sea floor. This same mushy trace flanks many of the banks in the Gulf of Maine (pl. 5) as a bordering apron. Adjacent to banks in the central gulf, the records show this mushy trace to be slightly hummocky, thus indicating a gently rolling sea floor. The lateral change basinward toward a double-bottom trace is fairly gradual. Scattered through the gulf are smaller areas of irregular hummocky topography with an opaque bottom trace. They range from a length of several hundred meters to several kilometers and are obviously older than the translucent layer.

The lateral persistence of some of the bottom traces and their relation to one another can be seen on plate 6 for a restricted area of the gulf. The translucent layer covers the basins irregularly. One east-west traverse through northern Platts Basin shows that some channelways are actively enough scoured to prevent any accumulation of sediment to a noticeable thickness. On almost every profile the irregular hummocky topography emerges from beneath the cover of fine-grained sediment. On some of the more closely spaced profiles such as those through Platts Basin, pockets of sediment cover and areas of buried irregular topography can be correlated by their similarity in position and shape.

A comparison of plates 5 and 6 with the sediment map (pl. 1) shows that some sediment types correspond to some of the bottom traces. Silty clay and clay make up most of the basin sediment in the western Gulf of Maine. In basins such as Jordan Basin, the change from a double-bottom to a mushy-bottom tract is accompanied by a transition from silty clay to silt or clayey silt. In the same area near the deepest part of the basin, one sediment sample reveals a mixture of sand, silt, and clay; this is the same part of the sea floor on which the echo-sounding records show a hummocky topography.

The area of mushy-bottom traces does not correlate as well with sediment pattern in the western gulf. Mixtures of gravel, sand, silt, and clay typify the hummocky mushy traces taken on the flanks of Platts Bank. This is probably because finer grained sediment in this area thinly veneers older glacial debris. Dives made on the flanks of Platts Bank and Jeffreys Ledge in DSRV Alvin by J. C. Hathaway (oral commun., May 1968) and the author reveal both areas veneered by silty sediment above coarse debris. In an attempt to probe the sediment thickness on a dive in DSRV Alvin near Platts Bank, Hathaway found the sediment underlain by a hard surface, presumably gravelly debris, a few centimeters below the sediment-water boundary. On another dive to the northwest side of Jeffreys Ledge, discontinuous bouldery pavement gradually emerged from beneath a silty clay covering on the upper flanks of the ledge. Hence, the silty apron may be so thin that in sampling it, some coarse debris can be gathered along with finer sediment.

Bedrock areas show up on the sediment map as coarse-grained gravel and sandy gravel because rock debris masks the rock platform to an unknown thickness.

A comparison of these echo-sounding records with sediment types has shown two main relations:

1. Different types of sediments in the Gulf of Maine are probably more patchy and discontinuous than are shown on the sediment map (pl. 1). Areas of till-like sediment with a hummocky topographic expression are shown on the records as isolated highs poking through a veneer of clay and silt of variable thickness. Further, the echo-sounding record shows small changes (hard to mushy trace) which probably reflect a change in the percentage of fine-grained sediment. The widespread sampling grid $(18 \mathrm{~km})$ may, however, fail to detect all these small patches of different types of sediment. 
2. A rudimentary textural gradation exists between some of the sediment types (fig. 28) in the glaciated parts of the continental margin. This

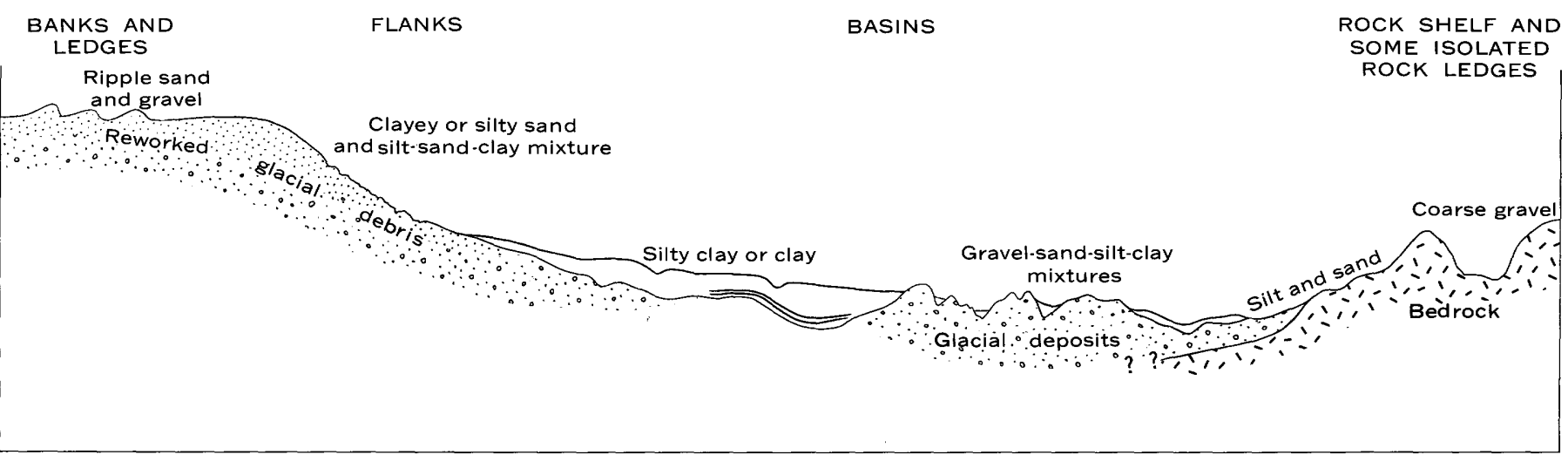

FigURE 28.-Schematic cross section showing lateral relationships of the different sediment types in the Gulf of Maine and adjacent areas.

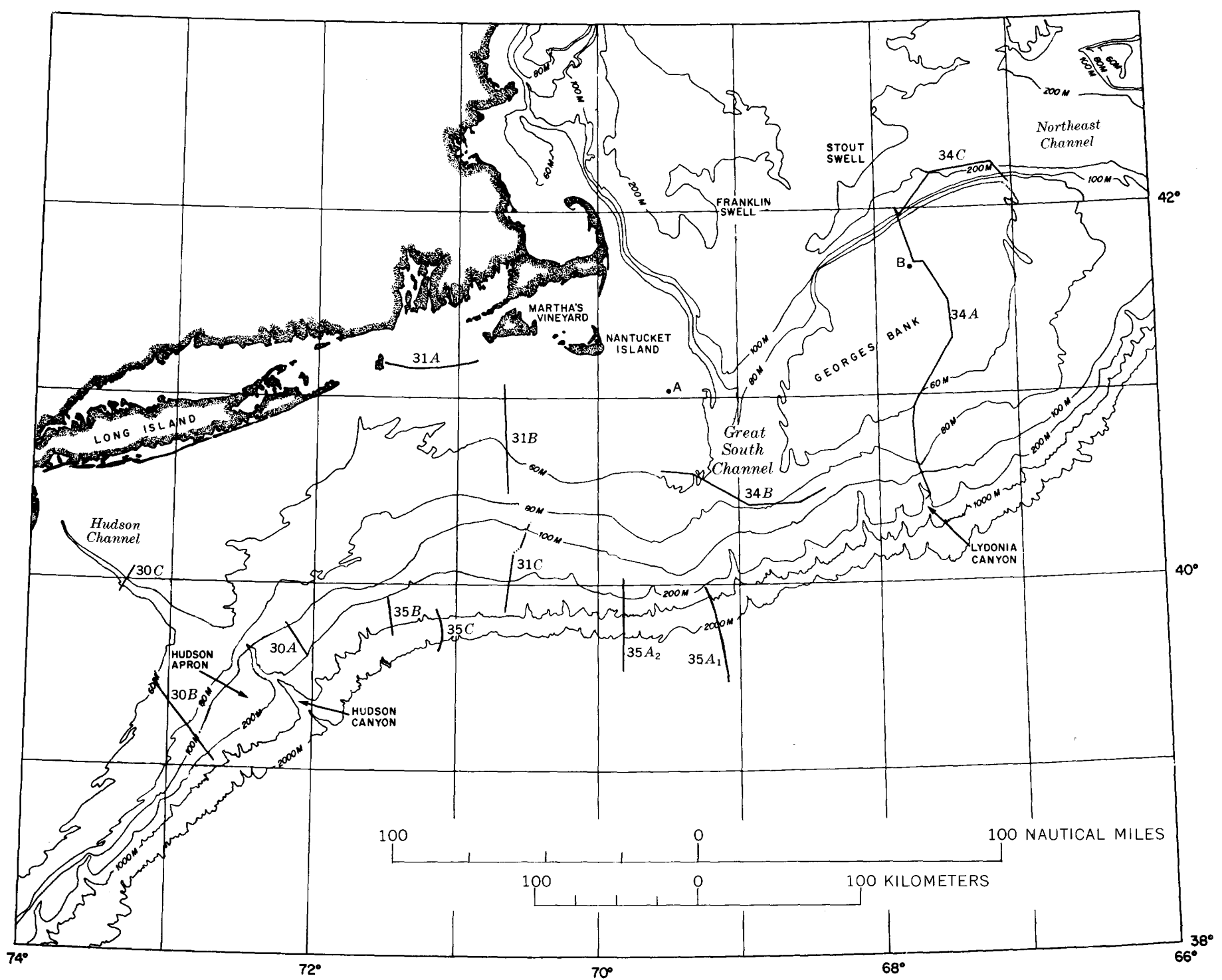

FIGURE 29.-Tracks for seismic profiles given in figures 30,31, 34, and 35. Track designations indicate figure in which profile is shown. Points A and B are Texas Tower sites. 
gradation has also been implied by Wigley (1961, p. 176) adjacent to eastern Cape Cod and by King (1967, fig. 4) on the Scotian Shelf. Admittedly it is a complex gradation because decrease in grain size basinward is interrupted by probable outcroppings of glacial deposits incompletely covered by reworked detritus obtained form the shallow banks and ledges.

Drill-hole data and shallow seismic profiles also add to the picture of sediment geometry, though more in terms of the gross stratigraphy. In a broad fashion, the profiles (fig. 29) indicate where the processes of erosion, slumping, and deposition have been active on the margin. With few exceptions, they do not relate directly to individual sediment patterns on the shelf because these surface patterns resulted during a time interval too short and too recent to be reflected in the seismic profile.
Profiles on the continental shelf off New Jersey and New York (fig. 30) have an intricate arrangement of reflectors which show cut-and-fill structures, low-angle truncation, and buried channels. The topmost layer reflects physiographic features like the Nicholls and Franklin shorelines (fig. 30). The sequences of cutting, burial, and retrenching have been particularly complex in the vicinity of Hudson Channel (fig. 30C) where several buried channels can be inferred. Toward the east (fig. 31A), the landward edge of the shelf (McMaster and others, 1968) has more buried channels, cuestas of Tertiary(?) and Cretaceous (?) strata also mantled by younger sediment, and discontinuous reflectors. Profiles across the shelf south of Martha's Vineyard reveal a more even layering in the uppermost part of the sequence, except toward the outer edge the shelf (fig. $31 C$ ) where older reflectors intersect the bottom. Textur-

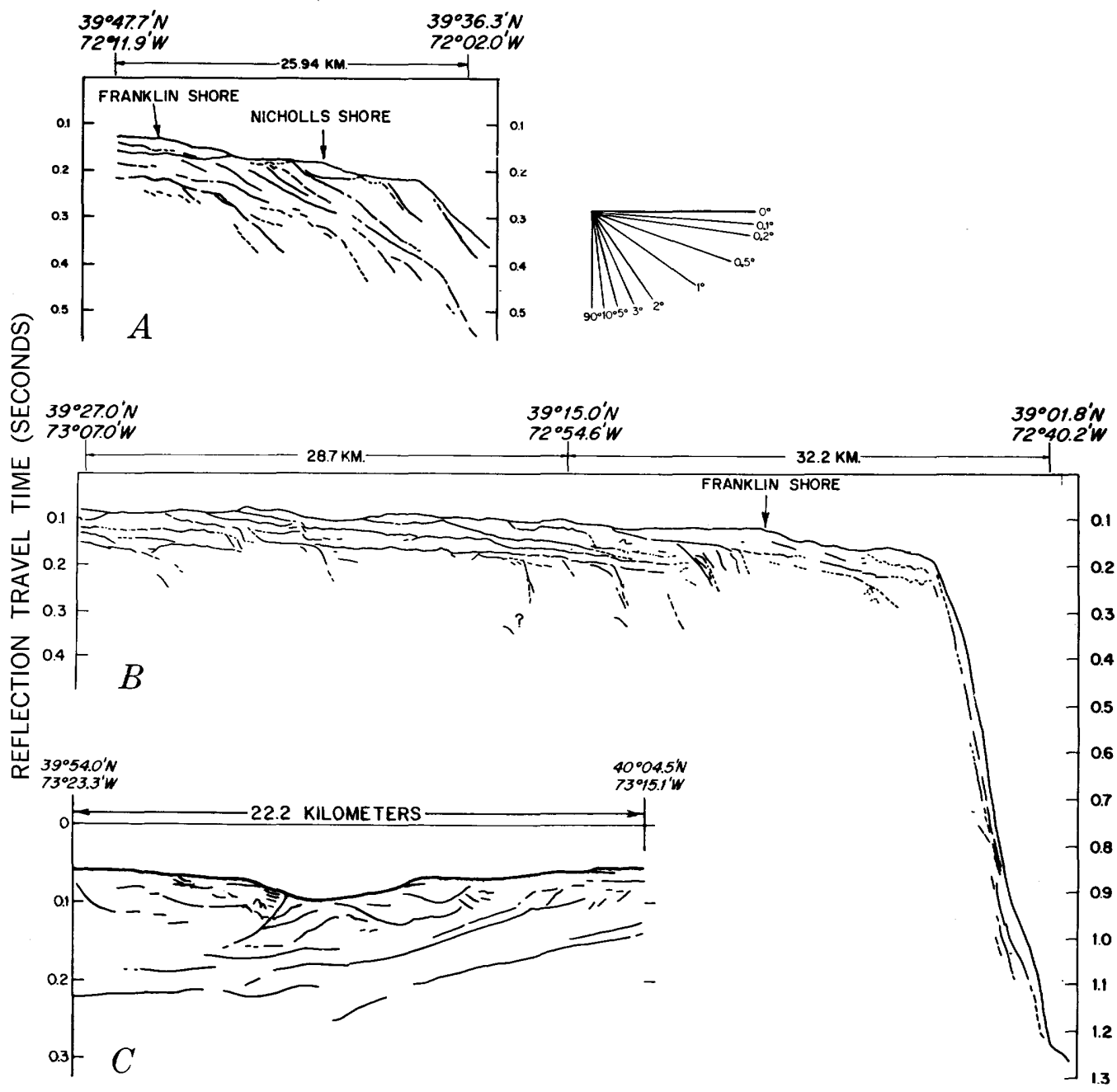

Figure 30.-Continuous seismic profiles of the New Jersey-Long Island area. Tracks shown in figure 29. Profiles $A$ and $B$ are on outer shelf and upper slope; profile $C$ is across the Hudson Channel (from Knott and Hoskins, 1968). 
ally, the two profiles (figs. $31 B, C$ ) cross the main area of sandy silt on the shelf south of New England.

The large patch of sandy silt on the shelf (south of Martha's Vineyard) is best interpreted as a relict wedge of sediment deposited during lower stands of sea level. The seaward edge of the unit shows up (fig. $31 C$ ) at about point $\times$ on the profile. Results of a coring and echo-sounding survey shown in figures 32 and 33 , indicate an accumulation of silty clay as much as 4 or $5 \mathrm{~m}$. The same double bottom shows up in Block Channel-Block Delta though it is thinner and is separated from the main area by a broad low ridge east of the channel, 8-16 $\mathrm{km}$ wide. The area of maximum core length overlaps the area of double bottom. The cores are almost entirely a uniform clayey silt, with a minor though persistent sand fraction; they show no obvious bedding or vertical textural zonation. The clayey silt is olive gray (5GY 4/2) (Munsell color system, Munsell Color Co. 1929-60) plastic, and contains Foraminifera as well as scattered pelecypod and echinoid fragments. The pelecypods are Venericardia borealis, Astarte undata, and Mesodesma deauratum; Foraminifera with a possible geographic significance include Globobulimina auriculata and Marginulina bacheii (T. G. Gibson, written commun., August
1970). Though none of these forms is foreign to this shelf area today, their dominance leads Gibson to conclude that most of the core samples he examined accumulated under conditions cooler than present; fauna from two cores show a warming trend toward the bottom of the core. Toward the shelf break as well as landward, sand becomes more abundant, the cores contain obvious layers of sand, and the core penetration is less (fig. 33). To the west on the divide with Block Channel, cores are interbedded silty sand and sandy silt, and penetration is low.

Radiocarbon dates from shallow-water shell fragments in the sand below the mud (Emery and Garrison, 1967, fig. 1 : locations $\mathrm{T} 307$, $\mathrm{T} 147$ ) reveal ages of 13,420 years before present for the sample obtained near the seaward edge of the silty area and 9,150 years before present for the sample taken in $55 \mathrm{~m}$ of water near the landward edge of the silty area. This still does not give the exact age of the overlying silt, except that it is less than 13,420 years old.

To judge by the ecology of the fauna and the radiocarbon dates, the sandy silt deposit appears to have formed during a part of the Holocene when the shoreline was about $60 \mathrm{~m}$ below the present level. The $60 \mathrm{~m}$ level is thought to be significant because:
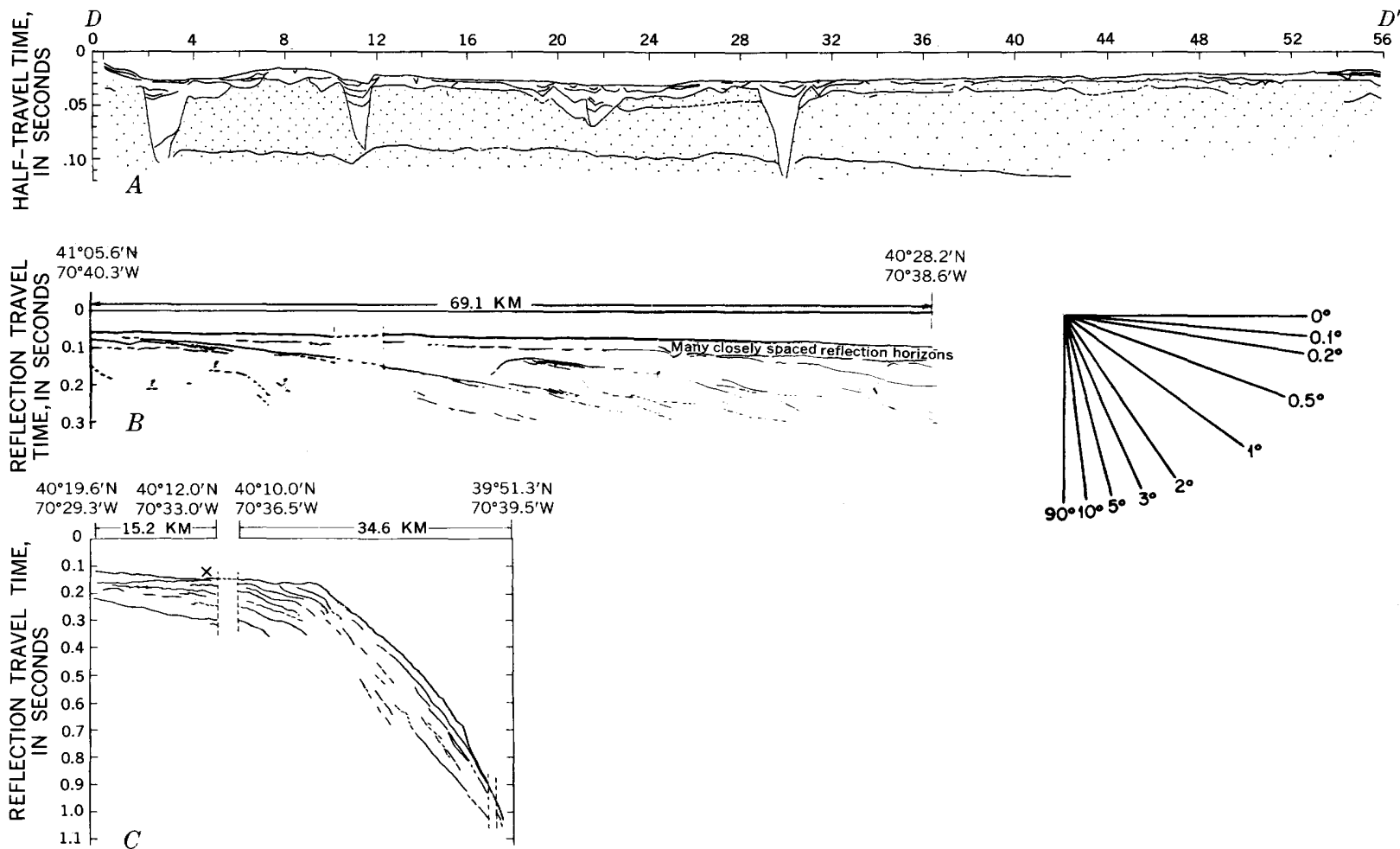

Figure 31.-Continuous seismic profiles on continental shelf and upper slope south of Rhode Island and Martha's Vineyard. Tracks shown in figure 29 ( $A$ from McMaster and others, 1968; $B$ and $C$ from Knott and Hoskins, 1968). 


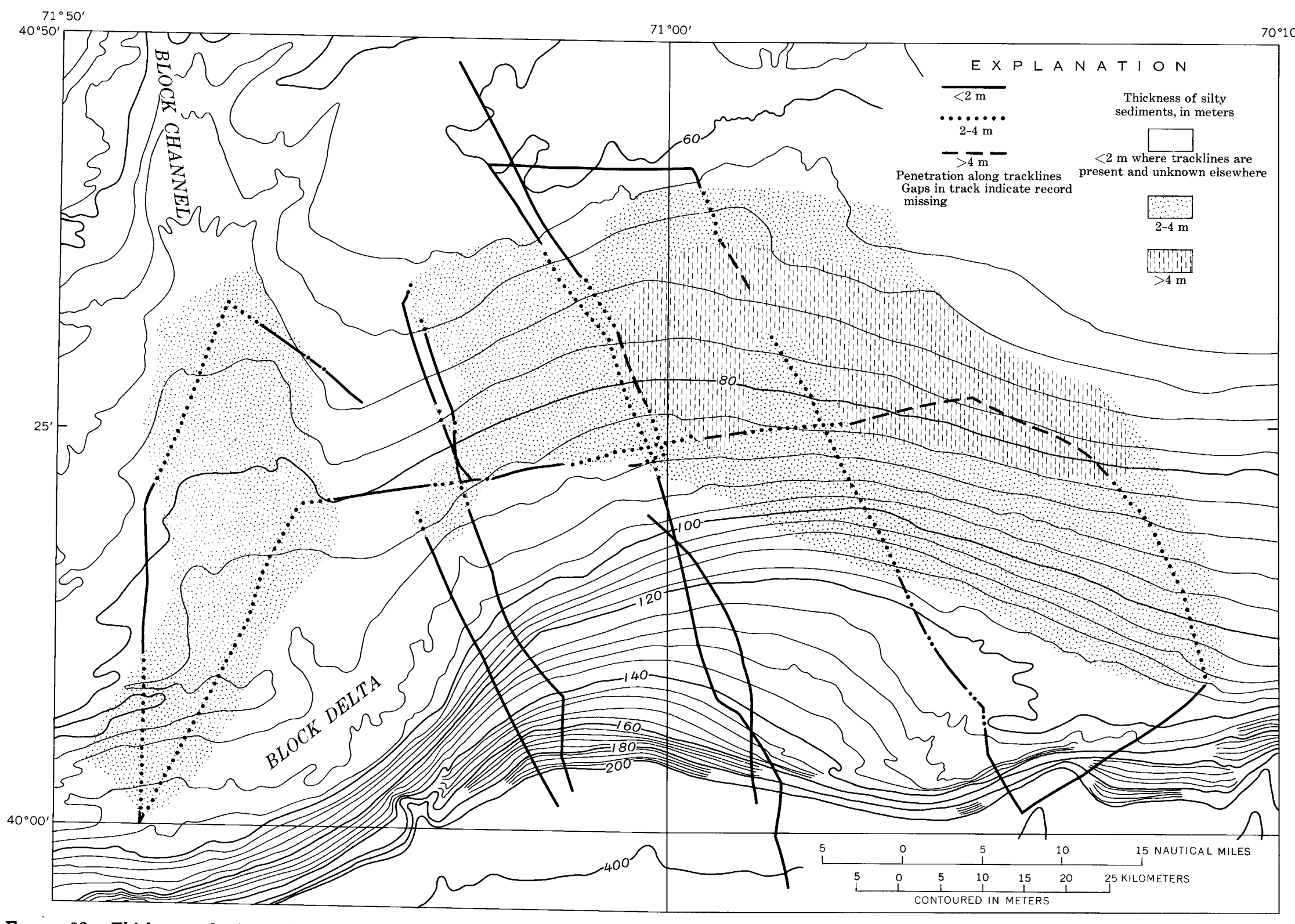


(1) the fine-grained detritus is almost entirely seaward of this contour, (2) this level shows as a terrace $(63 \mathrm{~m})$ on profiles across the shelf in this area, (3) several of the clean gravelly sands on the shelf both east and west of the area are at this level, and (4) the radiocarbon date of 9,000-10,000 years BP for this stage of sea level would be early enough in the Holocene to assure cold-water conditions. Why sediment accumulated south of Martha's Vineyard is not known except that the area is shaped like a broad open bowl, and perhaps during the lowered sea level, fine-grained detritus from wasting ice sheets was kept here on the open shelf to settle out through gyres of coastal-water circulation.

On Georges Bank (fig. 34), the profiles disclose a complex depositional history during the Quaternary. The several systems of buried channels are covered by horizontally layered sediment. Much of this uppermost material is sand with thin stringers of gravel and silty gray clay as shown by drill-hole data (J. M. Zeigler, written commun., July 1968) from Texas Tower sites on Nantucket Shoals and Georges Shoal (points A and B in fig. 29). Several holes were drilled on Georges Shoal, and one penetrated a little less than 120 feet of coarse to medium sand with thin stringers of silty sand and gravelly sand. Other holes drilled within a kilometer of this one, found gray clay at depths ranging from 53 to 68 feet below the sea floor. This sand prism is built up on much of the northern part of the bank, north of the system of buried channels (fig. 34). North of the shoals, profiles indicate (fig. 34, profiles $A, C$ ) a complex sequence of laterally discontinuous reflectors; the sequence unconformably overlies truncated eroded older strata along the northern flank of Georges Basin. Arrangement of reflectors (fig. 34, profile C) suggests that the sequence may dip toward the basin at a low angle $\left(5^{\circ}\right)$. These profiles have been interpreted as showing that ice overrode the northern part of the bank and plastered glacial debris there (Knott and Hoskins, 1968). Certainly the sediment samples and echo-sounding profiles, which show the area to contain spotty outcrops of till-like gravel projecting through a thin cover as fine-grained sand, lend support to such an interpretation. The glacial deposits cover an older drainage system and older sedimentary formations of presumed Tertiary and Cretaceous age to a thickness of several tens of meters (Emery and Uchupi, 1965).

Profiles from the continental slope (fig. 35) made by Hoskins (1967), Krause, Chramiec, Walsh, and Wisotsky (1966), and Uchupi (1967) support the transitory nature of sedimentation there and show how marked slumping and erosion have been. Some profiles show even prograding of sediment (fig. 35 $A-C)$, and, as such, may help to explain the fairly uniform transition from sand on the shelf to silty clay on the continental rise (pls. 1, 3 and fig. 9A). The slope, however, is incised by numerous canyons and gullies which have cut the prograded layers and have exposed older strata. This obvious evidence of erosion may explain the spotty variation in sediment type on parts of the slope. Cores taken on one small area of the upper continental slope south of Martha's Vineyard suggest a localization of depositional processes both temporally and areally (fig. 36). The cores are interbedded silty clays, sandy silt, and silty sand as fairly discrete units with sharp boundaries. They do not show a similarity in sequence with depth from core to core. Biogenic reworking has been spasmodic enough so that discrete units as thin as $1 \mathrm{~cm}$ (centimeter) are preserved.

The base of the continental slope (fig. $35 \mathrm{~A}$ ) marks a thinning or lensing of units and the beginning of a prism of sediments on the upper continental rise. The lower slope appears to be a transitory area so far as sediment disposition is concerned. Through mass wasting, current transport, creep, turbidity flows, and slumping, the sediment gets moved out onto the upper rise. Uchupi (1967) found evidence of slumping (fig. $35 \mathrm{C}$ ) on the slope in the form of toreva blocks or as imbricate slices. Again, both the thinning of the strata and slumping to expose older units tend to cause variations in the sediment texture, as can be seen in a series of anomalies along the continental slope (pl. 1; figs. 7 and 10). Sediment tends to be poorer in sorting, to contain more modes, and to be a mixture of sand, silt, and clay.

\section{GEOLOGIC HISTORY AND PROCESSES}

The complex vertical and areal pattern of sediment texture arises from multiple sources for the sediment and the combined effects of several processes that have transported and reworked detritus over the past several thousand years. An exact sequence of erosion, transport, and deposition cannot be determined in any one area, but the sources of the sediment and the processes (past or present) that have acted on them can be outlined.

\section{RELICT SEDIMENTATION}

Though the shelf has been gradually submerged and reworked during the Holocene, the sediment there still retains the imprint of Pleistocene sedimentation and erosion. It shows both in the topography, sediment type, and geometry, particularly on the glaciated part of the shelf. 


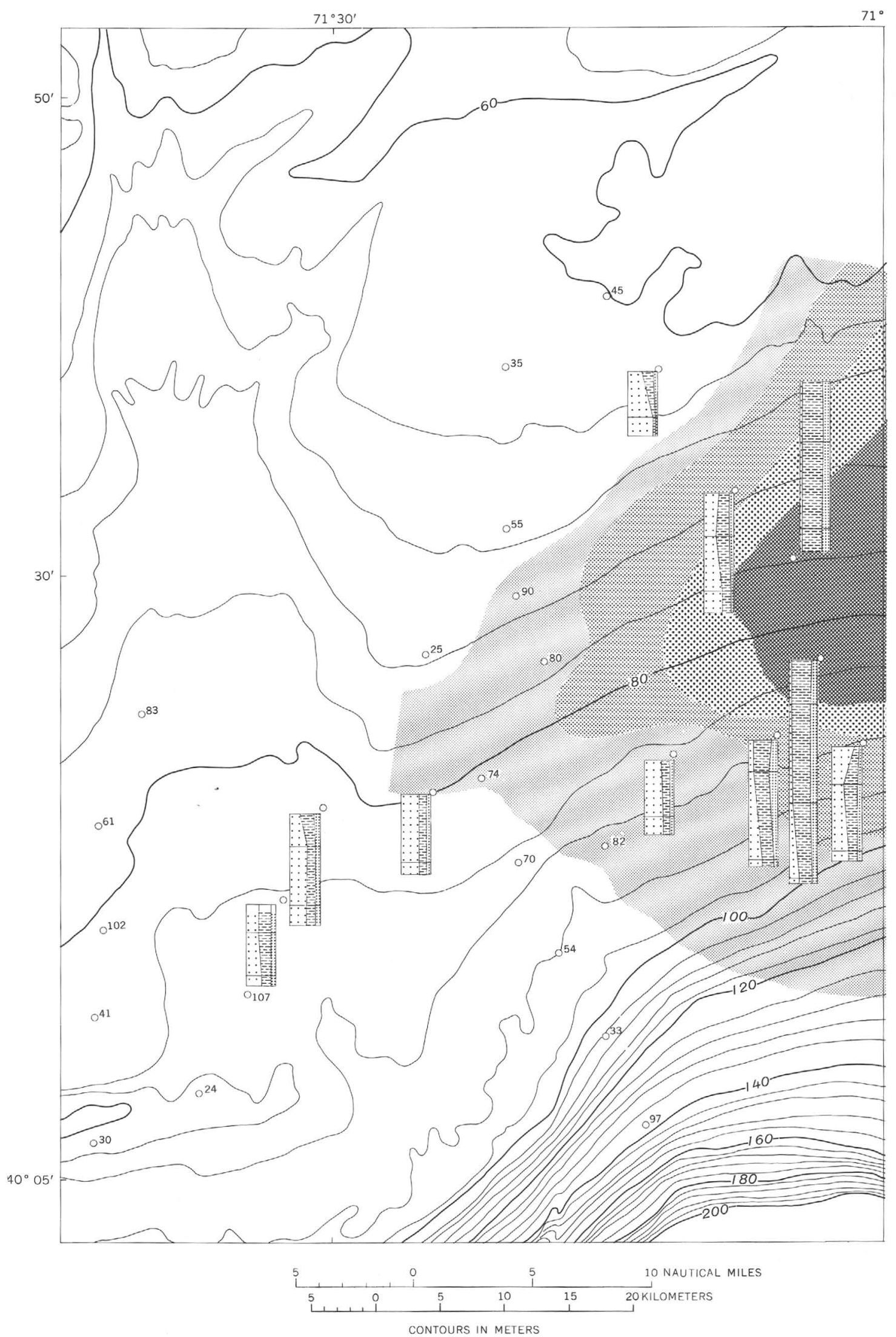

FIGURE 33.-Thickness and lithology of cores in the vicinity of Block Channel and the shelf south of 
$70^{\circ} 30^{\prime}$

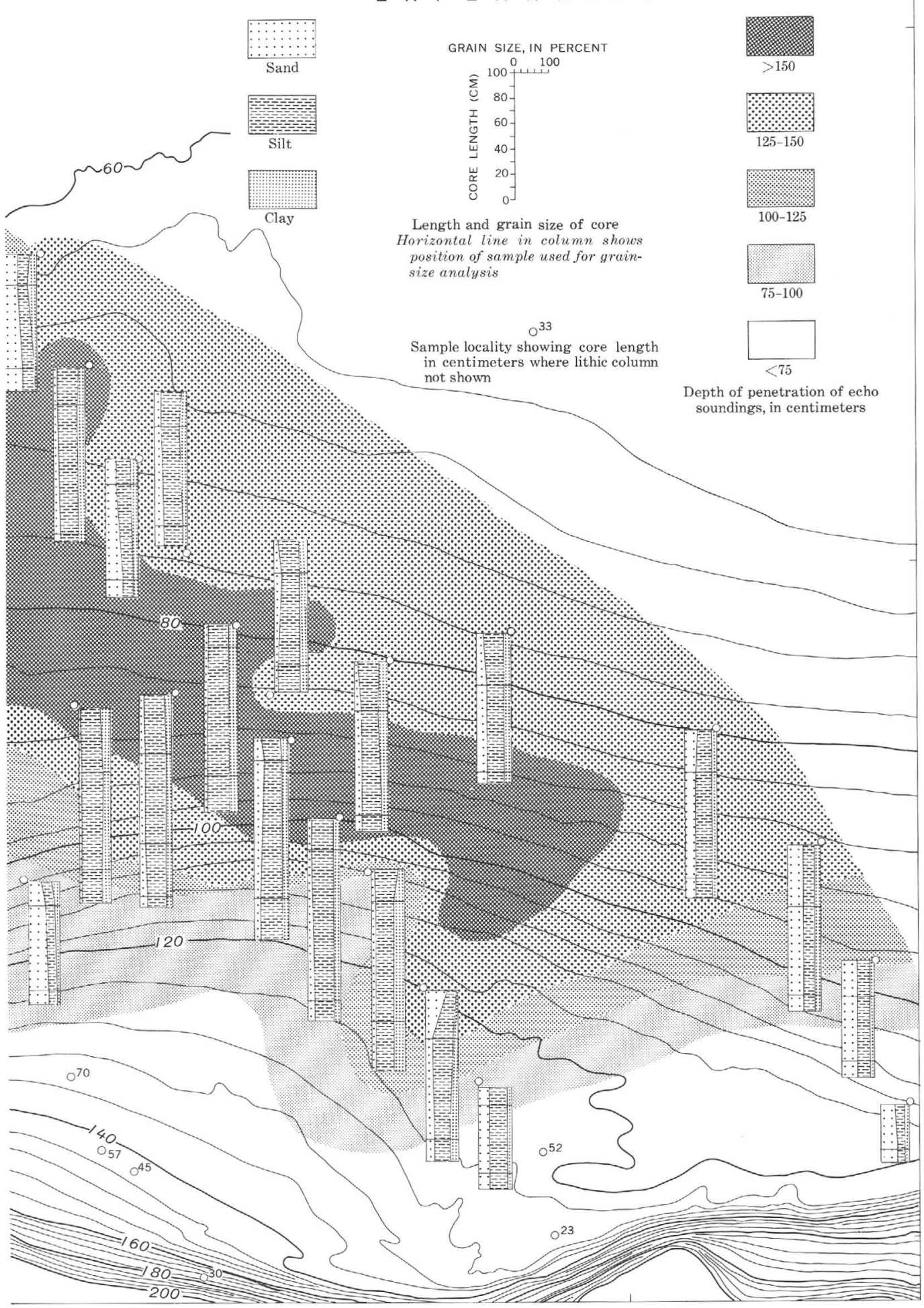

Martha's Vineyard. Cores courtesy of Bell Telephone Laboratories. Bathymetric contours in meters. 


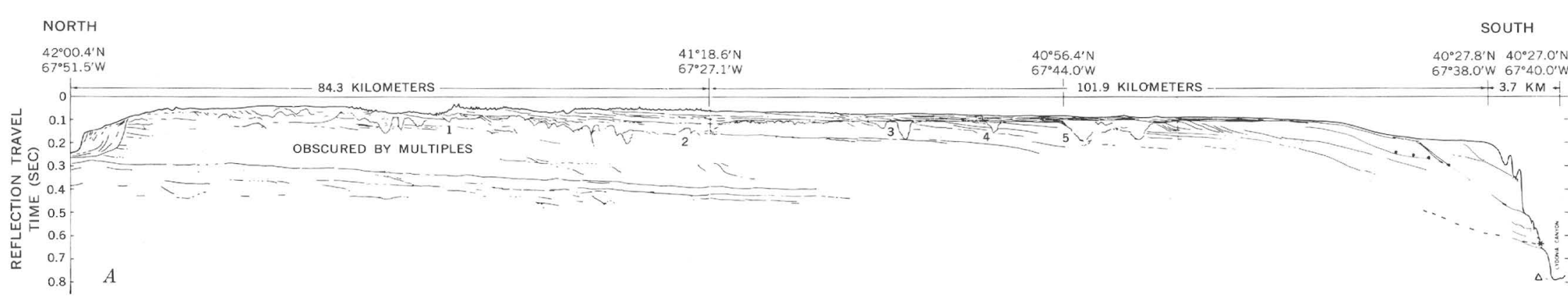

FIGURE 34.-Continuous seismic profiles across Georges Bank. Great South Channel, and Georges Basin (from Knott and Hoskins, 1968). 


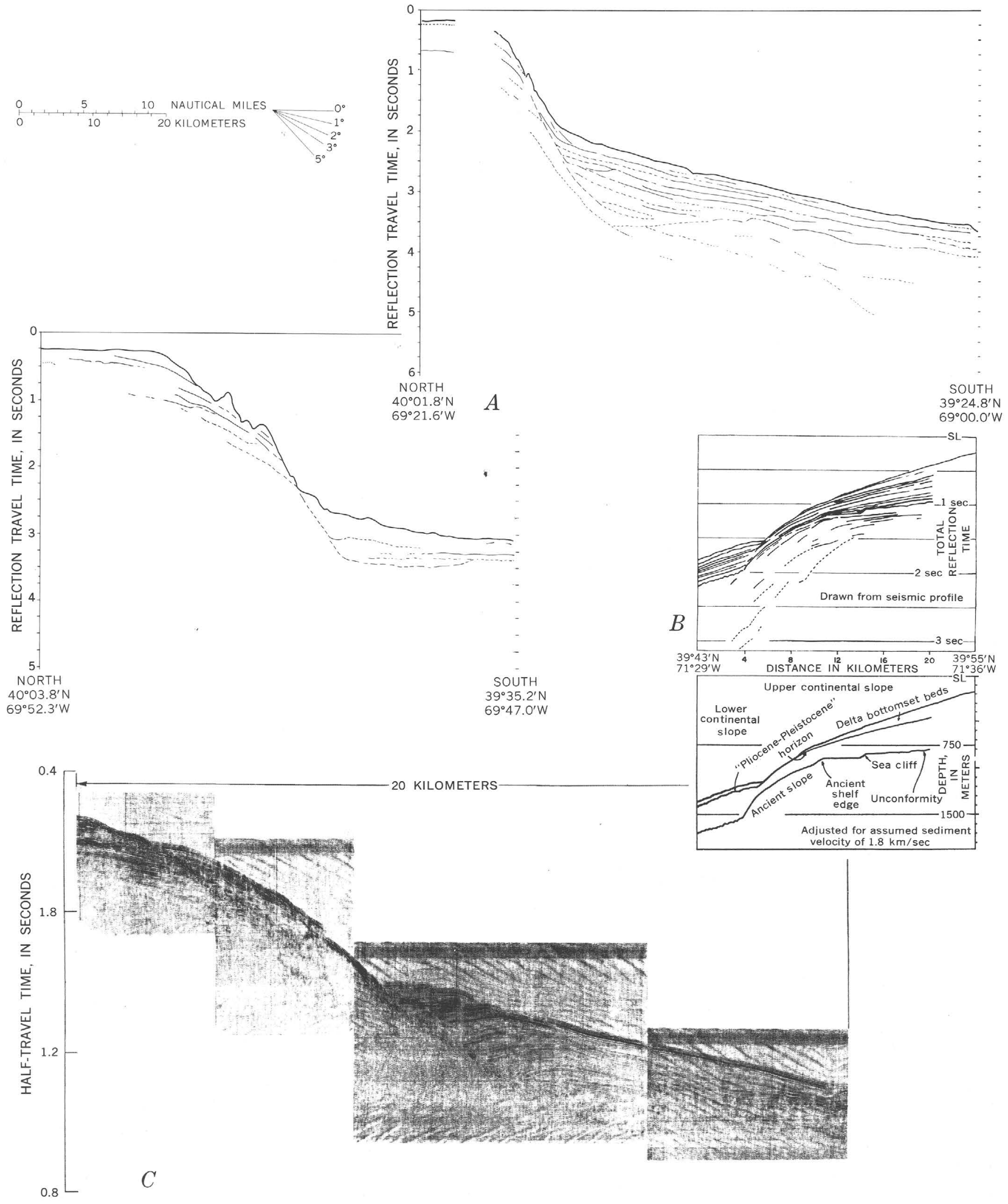

FIGURE 35.-Continuous seismic profiles of continental slope and upper rise. $A$ is from Hoskins (1967), $B$ from Krause, Chramiec, Walsh, and Wisotsky (1966), and C from Uchupi (1967). 

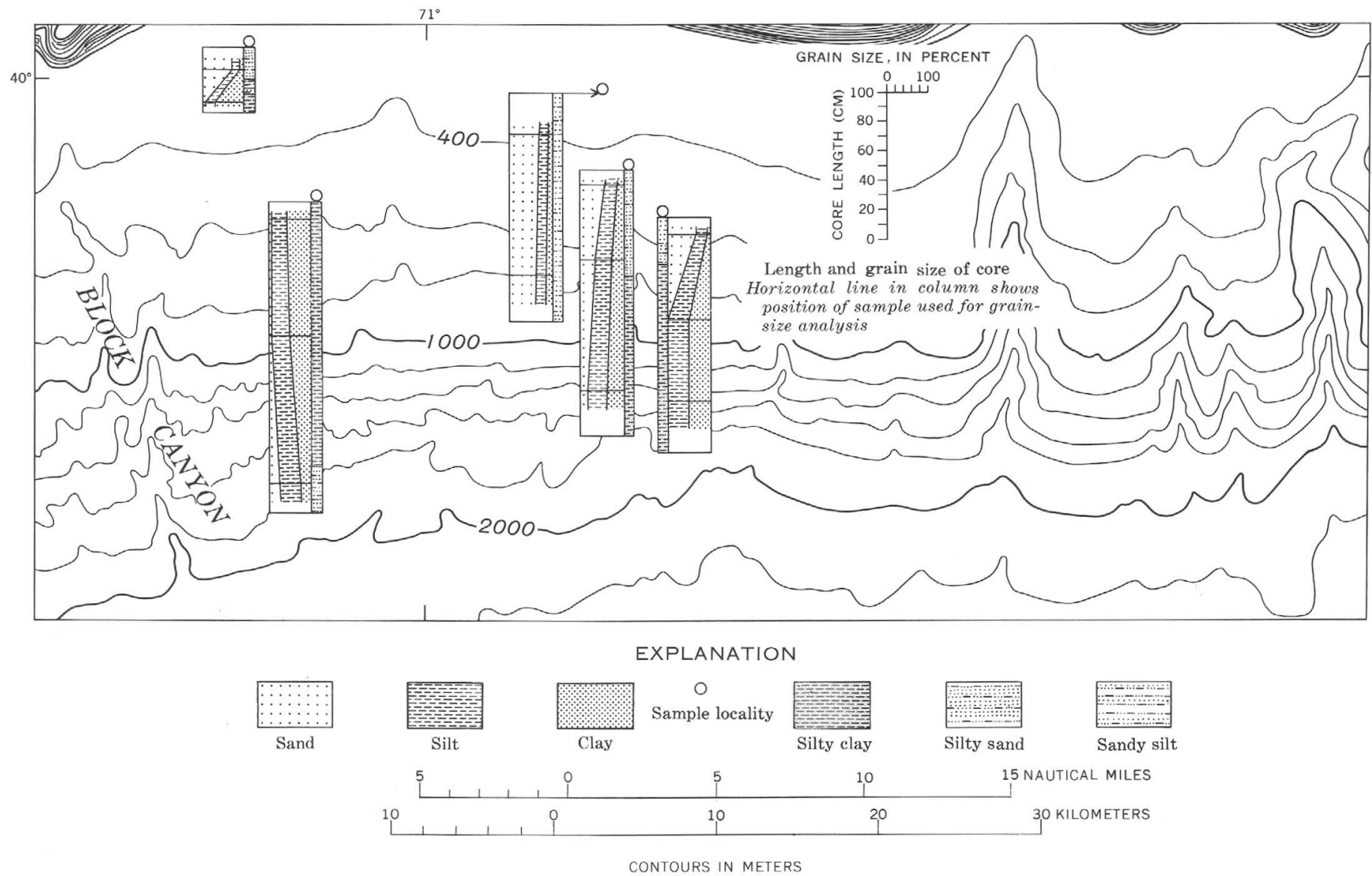

Figure 36.-Texture and length of five cores collected on the upper continental slope south of Martha's Vineyard. Cores courtesy of Bell Telephone Laboratories. Contours are in meters. Base from Uchupi (1970).

\section{GLACIAL SEDIMENT}

The effects of ice transport are most apparent in the Gulf of Maine. The association of hummocky topography and poorly sorted mixtures of gravel, sand, silt, and clay has been noted. Other textural similarities between this type of sediment and till have been shown by curve shape (pl. $4 D$ ), C-M diagrams (fig. 26 ), and sorting map (pl. $4 A$ ). The spotty concentrations of coarse gravel (pls. 2 and 3 ), visual observation of the bottom, and bottom photographs of glacial erratics in the same area also indicate the presence of glacial debris. As noted by Schlee and Pratt (1970), much of the gravel in the gulf has a multimodal size distribution, in part because of the wide size range of detritus available; further, the gravel has a large variety of rock types similar in composition to the local bedrock. Dilution rates from spotted schist outcrops adjacent to Nova Scotia follow the same mathematical function as found by previous investigators for land-glacial deposits (Schlee and Pratt, 1970, fig. 29).
The actual agent of glacial deposition may have been running water as well as ice, for though the sediment in part of the gulf has been termed "tilllike," the deposits obviously could and probably do include a whole group of associated deposits such as flowtill (Hartshorn, 1958) ice-channel fillings, kames, lake silts, kame deltas, and outwash. Deposits like these are all present on land (for example, the Taunton quadrangle, Hartshorn, 1967). The sampling mode and pattern do not permit distinguishing them offshore; hence, they are all lumped together as ice-contact drift.

Some areas offshore dominantly covered by glacial outwash form the southern most edge of glaciation on the continental shelf (Pratt and Schlee,..1969). These deposits are mainly sand and gravel, and their origin can be inferred through projection offshore from morainic sandy gravels mapped on land (Schafer and Hartshorn, 1965). The sandy gravels and gravelly sands have the polymodal curve shape and are moderately sorted. Modes are in the coarse 
sand and gravel range (pl. 3), and skewness and kurtosis values can range widely, as noted in figure 16. The deposits make up the shoals along the northern part of Georges Bank and appear as a thickened wedge of sediment on continuous seismic profiles (fig. 34). Much of the outwash here has been reworked and channels filled in to judge by the complex system of shoals on Georges Bank (Uchupi, 1968 , pl. 1) and southeast of Nantucket (U.S. Coast and Geodetic Survey and U.S. Bureau of Commercial Fisheries, 1967) and the migration of sand there today (Stewart and Jordan, 1964). Redistribution has heaped the sand into shoals and has left the gravel behind as a lag between the shoals, much as described by Stewart and Jordan (1964).

Final evidence of glacial sedimentation is icerafted debris found in fine-grained sediment on the continental slope and rise. This debris is most obvious in the gravel size range where it shows up in the grain-size distribution as a "tacked on" part to the main fraction of silt and clay (Schlee and Pratt, 1970). Almost all these ice-rafted gravel fractions show a wide range in pebble roundness and lithology, thereby indicating several different sources for the debris. Ice-rafting also probably contributed coarse sediment to basins of the Gulf of Maine, particularly during withdrawal of the ice sheet, but present-day contributions there are small, as indicated by the lack of coarse-grained debris in basin clays there.

\section{NONGLACIAL SEDIMENT}

Relict fluvial and strandline deposits characterize much of the nonglaciated part of the continental shelf. As shown in figure 2, they are most obvious topographically as shallow broad channels that cross the shelf and as a series of terraces or breaks in the slope that are subparallel to the bathymetric contours.

Ancient fluvial channelways are best preserved offshore of New York and southern New England. Associated terrace gravels southeast of Hudson Channel have many of the same features as their counterparts on land (Schlee, 1964). The gravelly sand that veneers this area displays the same tendency to "hold up" the topography as a cap, mainly because gravel is difficult to erode. Hence, the $40-\mathrm{m}$ contour (fig. 2) swings noticeably farther southwest of Hudson Channel than it does northeast of it. In addition, the gravel is quartzose, well rounded, limited in size range, stained by iron oxide, and it is in a bimodal association with sand (Schlee and Pratt, 1970). These are all characteristics shown by upland terrace gravels on the Coastal Plain of
Maryland, Virginia, and New Jersey. Block Channel also provided a channelway to the shelf edge, though this shows more clearly topographically than it does texturally; one small area in the channel has finer modal grain size (pl. 3) than adjacent areas, but for most of its length, it appears to be crossed by alternating zones of fine and coarse sand (pl. 3). Median grain size ( $\mathrm{pl} .2$ ) does tends to be less in Block Channel than the shelf to the west. Mineralogically, McMaster and Garrison (1966, figs. 6, 10) report a mixed heavy-mineral assemblage restricted mainly to the channel and unlike the shelf to the east or west. They also found a subdominant modal grain size $(0.144-0.062 \mathrm{~mm})$ restricted mainly to Block Channel (McMaster and Garrison, 1966, fig. 6), but even their maps show grain-size trends that cut at an angle to the channel. In the subsurface (McMaster and others, 1968; Krause and others, 1966), continuous seismic profiles show channeling on the shelf and deltaic foreset bedding at the outer edge of the shelf. From these studies it is apparent that though the form of the fluvial complex is still evident in the bathymetry and in continuous seismic profiles, surface sediments have been reworked enough to obliterate most indications of the fluvial episode of sedimentation.

An intricate set of strandline terraces replete with spits and hooks have been described by Uchupi (1968) at several elevations on the shelf and upper slope south of Martha's Vineyard (35, 43, 55, 63, $80,125,158$, and $210 \mathrm{~m}$ below sea level). In addition, McMaster and Garrison (1967) have described a shallower stand at $24 \mathrm{~m}$ near Block Island. The terraces show up (fig. 2) as a bunching of the bathymetric contours over limited distances of a few tens of kilometers. In seismic-reflection profiles (Knott and Hoskins, 1968, figs. 6-8), deposits associated with the outer shelf terrace shorelines are distinctive enough so that the authors have been able to map the areal extent of unconformities associated with them.

Texturally, the sand on these terraces is well sorted, and similar to modern beach sand of the Atlantic coast. The sand overlaps broadly in C-M values with beach deposits (fig. 26) and shallow water shelf sand. Some elongate zones of sand with a coarse modal grain size parallel and overlap the outer shelf strandlines south of Rhode Island and on Georges Bank (pl. 3). A few scattered patches of gravel occur midway across the shelf south and east of Long Island (pl. 1), all approximately at 60 $\mathrm{m}$ water depth; these gravelly areas may mark a place where the sea level paused long enough for 
the terrace at $63 \mathrm{~m}$ (Uchupi, 1968) to be cut.

All the textural properties are discontinuous, just as the topographic scarps are discontinuous over much of the shelf. Further, there is a broad overlap in the properties of these relict littoral deposits with the shoal-water marine sands in active transport. Hence, though textural characteristics such as the sorting and curve shape may lend some support to interpretation of these offshore deposits as ancient littoral deposits, they do so only in a supporting manner.

\section{MODERN SEDIMENTATION}

The most recent rise in sea level over the past 16,000 years probably would have the most effect on the sedimentary patterns on the continental shelf. Redfield (1967) showed that the rate slackened from about $11 \times 10^{-3}$ feet per year to $2.5 \times 10^{-3}$ feet per year approximately 4,000 years ago. Hence, the part of the sea floor that should have begun to adjust to modern hydrographic conditions both in the topography and in the sediment, ought to be the landward part of the shelf out to a water depth of several meters.

\section{NEARSHORE SEDIMENT}

As shown in figure 2, the most obvious features adjacent to the strandline are systems of submarine sand and ridges. They are most pronounced adjacent to straight stretches of the coastline and where a ready source of sand from formations of the Coastal Plain is available. On Georges Bank and Nantucket Shoals, complex sinuous systems are developed, again where there is a source of sand readily available, and where depths are shallow. The linear systems off Long Island and New Jersey are similar to those studied by Moody (1964) off Delaware. He found the development of offshore sand ridges to be related to landward migration of the barrier beach island, particularly during drastic storms. Careful surveys made over a 42-year period (1919-1961) showed that the strandline migrated $25-85 \mathrm{~m}$ landward and that the offshore sand ridges migrated southeast as much as $250 \mathrm{~m}$. During the disastrous storm in March 1962, Moody found that the ridge crests moved a maximum of 70 meters southeast. An estimated $10^{6} \mathrm{cu} \mathrm{m}$ (cubic meters) of sand was eroded from the north-facing slope of the ridges and moved southeast farther offshore in the direction of ridge migration. A main conclusion of Moody's study is that the inner shelf out to a depth of at least $10 \mathrm{~m}$ is covered by sediment which is in periodic movement through the combined efforts of storm waves, tidal currents, longshore bottom currents, and rip currents. Much the same processes have shaped the sea floor off coastal New Jersey (Charlesworth, 1968). Charlesworth finds sediment grain size, sorting, and skewness related to the sand-ridge topography offshore (Charlesworth, 1968 , pls. 22, 27, 32) and a tendency for this to show up most clearly in residual maps based on trend analysis of the data. After extensive study of the waves and tidal currents, he concludes that dayto-day waves are effective in shaping the sea floor to a depth of 6-12 feet mean low water and that "storm conditions and nearshore currents are more responsible for deeper water sediment distribution and bottom topographic features ***." (Charlesworth, 1968 , p. 180). Several other studies analyzed the dynamics of sand transport in shallow areas (Smith, 1969; Owen and others, 1967) mainly through the action of tidal currents. Houboult (1968) found abundant evidence of sand transport in the southern bight of the North Sea. Sand from glacial sources has been swept into a series of ridges, megaripples, and banks-features which continue to migrate mainly under the influence of tidal currents. All these studies plus the work of Off (1963) and Stewart and Jordan (1964) show that the inner shelf is actively being reworked and sediment is being redistributed as a result of the combined efforts of storm waves and longshore current drift. Thus, to a depth of at least 15 meters we should expect sediment to be in some sort of periodic movement and in adjustment to the current dynamics there. The adjustment is reflected in the texture characteristic of the sand that covers this part of the shelf. It has a modal size in the fine to medium range $(1 / 8-1 / 2 \mathrm{~mm})$ and it well sorted. Its curve shape is log normally distributed and steep, similar to the wave-washed beach sand along the coast, and similar to other analyses of nearshore shelf sands elsewhere (Klovan, 1966). Passega diagrams (figs. 25, 26) also show that most of these shallow-water sands plot in the tractive current domain. All these textural features lend support to the ideas that the inner edge of the shelf and shoal areas like Georges Bank are veneered by modern sediment looked at in terms of transport by bottom currents. As noted before, much of the sand is ancient in source because it was introduced to the inner shelf by processes other than those operating there today.

The question arises as to what sort of profile of marine equilibrium has formed in spite of (1) recent shifts in sea level and (2) multiplicity of sediment sources on the continental shelf? The classic one, most recently discussed by Dietz $(1963,1964)$, 
Moore and Curray (1964), and Curray (1965), of a gently sloping apron of sand does exist at the shallow edge of the shelf. The only question is how far does it extend seaward? Dietz (1964, fig. 13) would include only the smooth gently sloping part of the sea floor immediately seaward of the surf zone. Yet, as shown by Moody, the sediment on the sand waves beyond this zone also is in movementinfrequently, but still in movement. The outer limit of a marine profile of equilibrium is difficult to define, for, as noted by Moore and Curray (1964, p. 1267-1268), the depth of effective wave base depends on the type of sediment to be transported and on the sea state. For purposes of this paper, it would be at least $15 \mathrm{~m}$, perhaps extending to $20 \mathrm{~m}$, if the development of sand ridges is used as a guide (Uchupi, 1968). Some systems of ridges such as those south of Long Island are considerably deeper than $20 \mathrm{~m}$; others disappear in less water depth. What the topographic profiles and current studies in this inshore area seem to show is that the zone is considerably more comp'ex bathymetrically than a gently deepening surface seaward of the surf zone, and more complex in sediment texture than the sampling for this investigation can bring out. The well-sorted sandy sediment adjacent to the surf zone has been described, but it is not much different from the sand covering much of the rest of the shelf. We can also notice the decrease in modal grain size (pl. 3) of this same area of the shelf, but this is not persistent along the shore. More detailed sampling in this zone by Moody and Charlesworth does show a relation between the sandridge topography and the sediment grain size, but because the topographic change to intermediate areas of the shelf is not a smooth gently deepening one, change in mean grain-size depth is not a simpie linear one; the same is true for other statistical parameters measured by Charlesworth (1968).

Along much of the shoreline adjacent to New England, the profile of marine equilibrium lacks the systems of sand ridges. Here the coastline is twisted and interrupted by rocky headlands; hence, offshore wave patterns are more likely to be refracted by the coast and by an uneven sea floor. Zeigler and Ronne (1957) and Zeigler, Tuttle, Giese, and Tasha (1964) have shown a series of discontinuous bars offshore on outer Cape Cod parallel to this straight stretch of coast. Much of the shallow current-winnowed part of the sea floor off southern New England is in areas where glacial debris has been deposited as moraines and outwash in sufficient amounts to provide an ample supply of sediment for tractive cur- rents to heap it into sand shoals. A subaerial-marine example of this is the one described by Zeigler on outer Cape Cod where shoreline retreat into glacial outwash provides the sand for offshore bars; a submarine example is the reworked glacial debris of Nantucket Shoals.

Adjacent to the rocky coast of Maine, New Hampshire, southern New Brunswick, and Nova Scotia, sediment texture reflects a compromise between the rocky debris available and the limited ability of the bottom current to winnow and sort it. The swift geomorphic change from a gravelly rocky ledge or highland to a deep bay results in a patchiness in grain size; curve shape (pl. $4 D$ ) shows similar changes over short distances. Adjacent to the rocky shelf off Nova Scotia, gravel is sufficiently abundant from marine and glacial processes for polymodal size distribution to be prevalent. Any profile of equilibrium deve:oped along this coast or northern New England is likely to be a discontinuous one adjacent to sandy pocket beaches between rocky headlands, and interrupted offshore by discontinuous patches of gravel.

In summary, this study lends support to the idea of a nearshore part of the shelf in equilibrium with tidal currents and wave patterns. In straight stretches of the coast (New Jersey and New York) the profile is in two parts topographically-a gently sloping area out from the surf zone and areas of sand ridges whose axes are at an acute angle to the coast. Textural patterns reflect the complex topography in this zone. The seaward limit of this current-swept zone is difficult to fix. Where the sand ridges are present, they disappear in water depths of $15-20 \mathrm{~m}$. Seaward of this depth, other sand ridges are present, but they tend to be subparallel to the coastline and may represent submerged barrierisland complexes that originated during the Holocene rise in sea level. Adjacent to the sinuous part of the coast, the current-swept zone includes at least the area immediately seaward of the surf zone and can include one or more offshore bars. The zone is less easily defined in a seaward direction because of the paucity of sand and the marked variation in depth over comparatively short distances (basins, ledges, bays, and banks).

\section{OFFSHORE SEDIMENT}

A previous section stressed associations of offshore relict sediment with presumed ancient nearshore topography and biota in the much deeper water of the outer continental shelf. The widespread occurrence of dead oyster shells (Crassostrea virginica) over the shelf (Merrill and others, 1965) 
and fresh-water peat (Emery, Wigley, and Rubin, 1965 ; Emery and others, 1967) having progressively older radiocarbon dates toward the outer part of the shelf, indicate a lack of sedimentation on the middle and outer parts of the continental shelf. Does this mean that there has been no sediment movement?

Several lines of evidence indicate a reworking of all parts of the shelf. First, from a theoretical consideration of storm-wave-induced currents, Draper (1967) has calculated that oscillatory water particle speeds of greater than $0.9 \mathrm{~m} / \mathrm{sec}$ (meters per second) would be exceeded at a depth of 100 feet $3-4$ days per year at one wave observation station (off southwest England), and $1 / 3 \mathrm{~m} / \mathrm{sec}$ at the same depth and frequency for two other stations in the Irish Sea and English Channel. Both values are sufficient to cause the movement of sand. Similar calculations have been made for a greater depth on the outer shelf west of Ireland by Draper (1967, fig. 2), and they show water velocities greater than $1 / 3 \mathrm{~m} / \mathrm{sec}$ at a water depth of 600 feet exceeded again about 3-4 days per year. Obviously, these velocity projections based on analysis of wave spectra need to be coupled with actual current measurements close to the bottom to see if the wave data and currents are of the same magnitude.

Actual current measurements provide the most direct evidence for the magnitude of bottom currents (fig. 37) and indicate magnitudes sufficient to move sand. Velocities of as much as $45 \mathrm{~cm} / \mathrm{sec}$ (centimeters per second) have been noted by N. P. Fofonoff and his associates on the basis of current measurements made for several days from a moored buoy (Fofonoff, 1968) ; all his data cited in figure 37 were taken within a few meters of the bottom. The currents were in response to tides and storms (Fofonoff, 1968).

Another indication of modern transport by bottom currents on the outer continental shelf comes from bottom drifter patterns. The pattern was discussed earlier (fig. 9B') and finds additional support from Griscom (1968, fig. 3), who measured currents from a Texas Tower on the shelf south of Long Island; he found a residual drift to the west northwest of $5 \mathrm{~cm} / \mathrm{sec}$, as observed at a depth of 100 feet, 85 feet above the bottom.

All these current features, plus more cited in the earlier section on "Nonglacial Sediment" page L49, indicate that the outer shelf has made a partial adjustment to currents that sweep the area. Sand may be rippled and shelf debris may be heaped in windrows, but these patterns are the result mainly of oscillatory or storm currents. Long-term drift of sediment and obliteration of Holocene patterns of sedimentation have not gone on long enough to give rise to a shelf totally in equilibrium with current regimes. Donahue, Allen, and Heezen (1966) have concluded the reverse and cite as evidence for total reworking, the widespread blanket of well-sorted sand with ripple marks and the shell debris that covers the shelf. Further, the sand is underlain by sediment of a different lithology (generally clay) over much of the New Jersey shelf where Donahue, Allen, and Heezen (1966) made their study. These pieces of evidence, though interesting, are not compelling indications of total modern reworking of the shelf sand. They must be considered in light of the radiocarbon dates of older shelf debris toward the shelf edge, the terraces of presumed older stands of sea level still preserved on the shelf, the alternation of coarse and fine sands (modal size) offshore, old channels preserved on the shelf, and a few large areas of mud on the shelf.

\section{CONTINENTAL SLOPE SEDIMENT}

The nature of the sediment and the acoustic profiles suggest that the slope is a transitory area of sedimentation marked by influx of sand from the shelf and a pelagic rain of fine detritus; mixing of the two fractions probably occurs through slumping, slow downslope creep, and biogenic reworking. As noted in the discussion of curve shape, the sediment of the slope has textural characteristics similar to the sandy sediment on the shelf and the silty clays of the continental rise. The slope sediments are skewed mixtures of quartzose sand and finer grained sediment; farther down the slope, carbonate detritus, mainly Foraminifera tests, becomes prevalent in the sand fraction (Hülsemann, 1967, p. 139) though still minor as a weight fraction. Using heavy minerals from the sand fraction, Ross (1970) concluded that much of the sand on the slope was derived from the shelf and was probably emplaced when sea level was much lower. The increase in the amount of sand in shallower waters of the shelf (pls. 1 and 2) and the tendency for skewed curves to be transitional with pelagic sediments of the deeper areas and with the well-sorted sands of the shelf, suggest (1) that the sand has come partly from the shelf, and (2) that the pelagic component becomes a most important fraction in deeper water on the lower part of the slope. The seismic profiles and dredge hauls (Gibson, 1965; Northrop and Heezen, 1951) indicate the likelihood of mixing through slumping and redeposition. The poor correlation of units between cores taken on the upper 


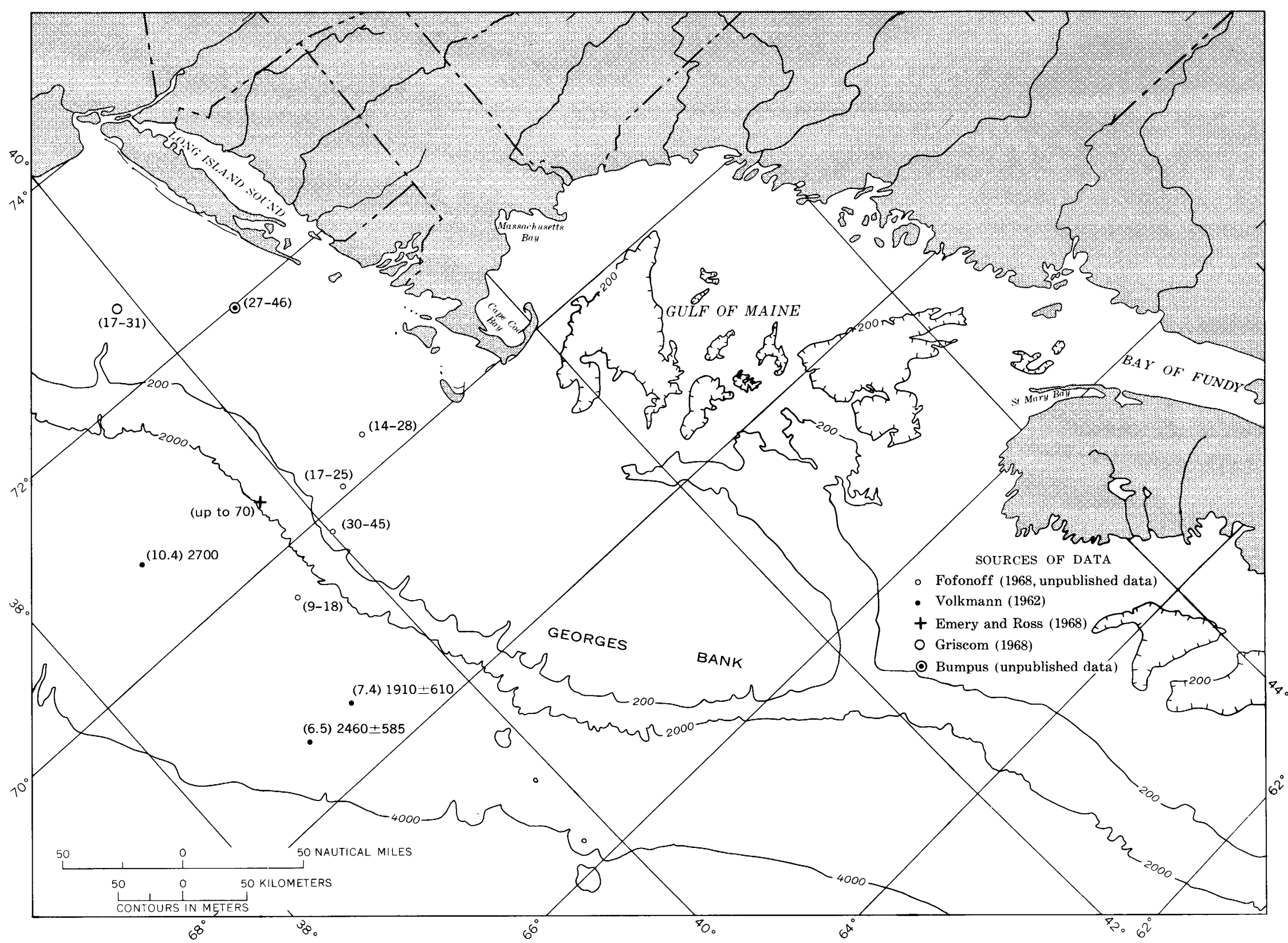

FiguRE 37.-Current-velocity measurements $(\mathrm{cm} / \mathrm{sec})$ on continental margin. Range is given in parenthesis. For drogue stations, depths (meters) are given to the right of the velocities. Contours in meters. 
slope (fig. 36) supports the idea of localized sedimentation. The most obvious evidence of erosion and downslope movement of sediment is in submarine canyons. The observations of Trumbull and McCamis (1967), Dill (1964), Rad (1968), and Stanley and Kelling (1968) show submarine canyons to be passageways for sediment carpets of sand and coarser debris to move to the deep ocean floor. Away from the canyons, slumpage, biogenic reworking, and slow downcreep movement may be more important agents to mix the pelagic contribution with older coarse detritus and move it downslope.

\section{CONTINENTAL RISE SEDIMENT}

The continental rise shows a more compiete sedimentation record (fig. 35) than the slope, to judge by seismic profiles (Hoskins, 1967; Uchupi and Emery, 1967) and cores (Schneider and others, 1967). Echograms show the sediment draped evenly over topographic features such as ridges and knolls (Lowrie and Heezen, 1967). Sediment types over the upper rise are more uniform than on the slope;

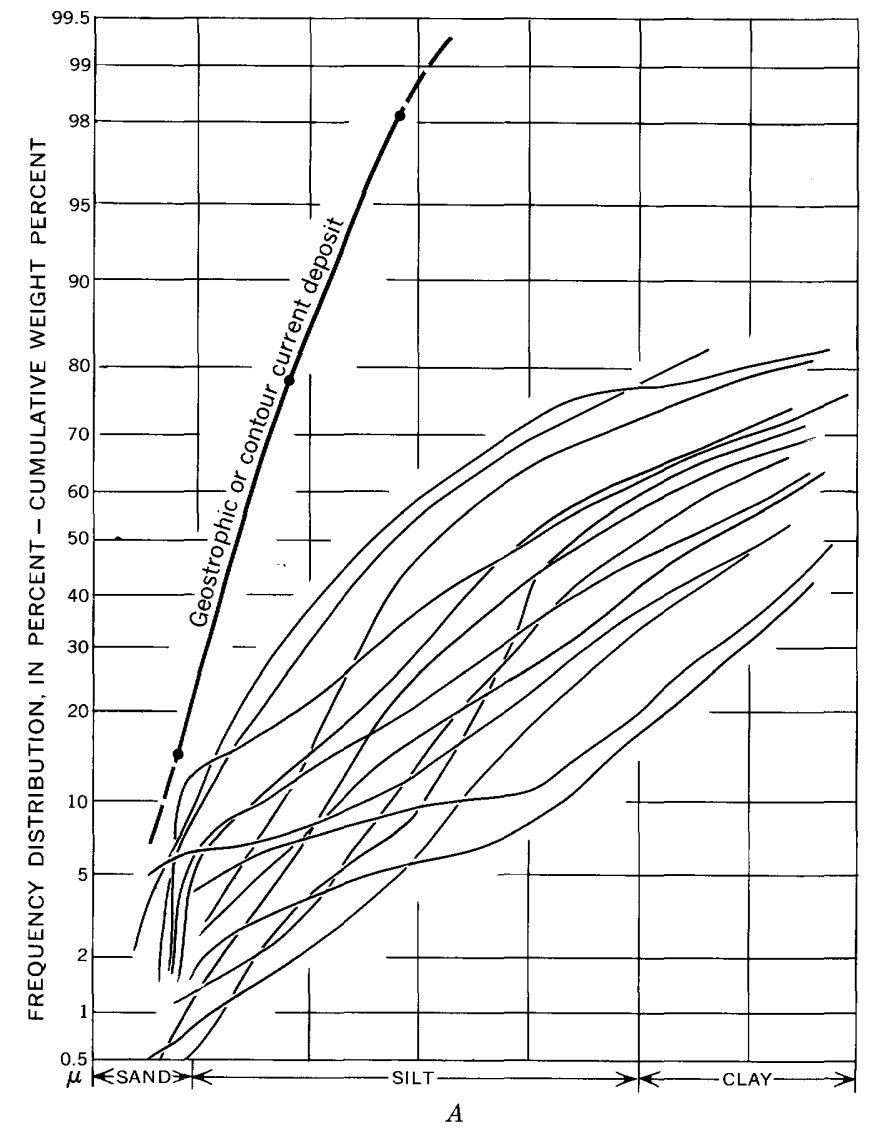

mainly they consist of clayey silt or silty clay with a log-normal distribution. Median and dominant modes are in the fine silt and clay range, and the sediment is moderately sorted. Skewness values are positive (tail of fine detritus) and kurtosis is negative (filling out on flanks of the curve). The openness of sediment patterns reflects in part a wide spacing of sampling and also more uniformity in sedimentation.

Three processes are likely dispersal agents for the fine-grained sediment-contour or geostrophic currents, gravity settling from the sea-water column, and turbidity flows. Size analyses of geostrophic deposits are lacking (fig. 38A). From descriptions by Heezen and Hollister (1964) and Schneider, Fox, Hollister, Needham, and Heezen (1967), the contour-current deposits appear fairly well sorted, and dominantly silt with some very fine grained sand, and are cross laminated; most characteristics fit the normally distributed silty clays poorly, inasmuch as the clays are homogeneous, have moderate sorting, lack much sand, and contain much detritus finer grained than silt.

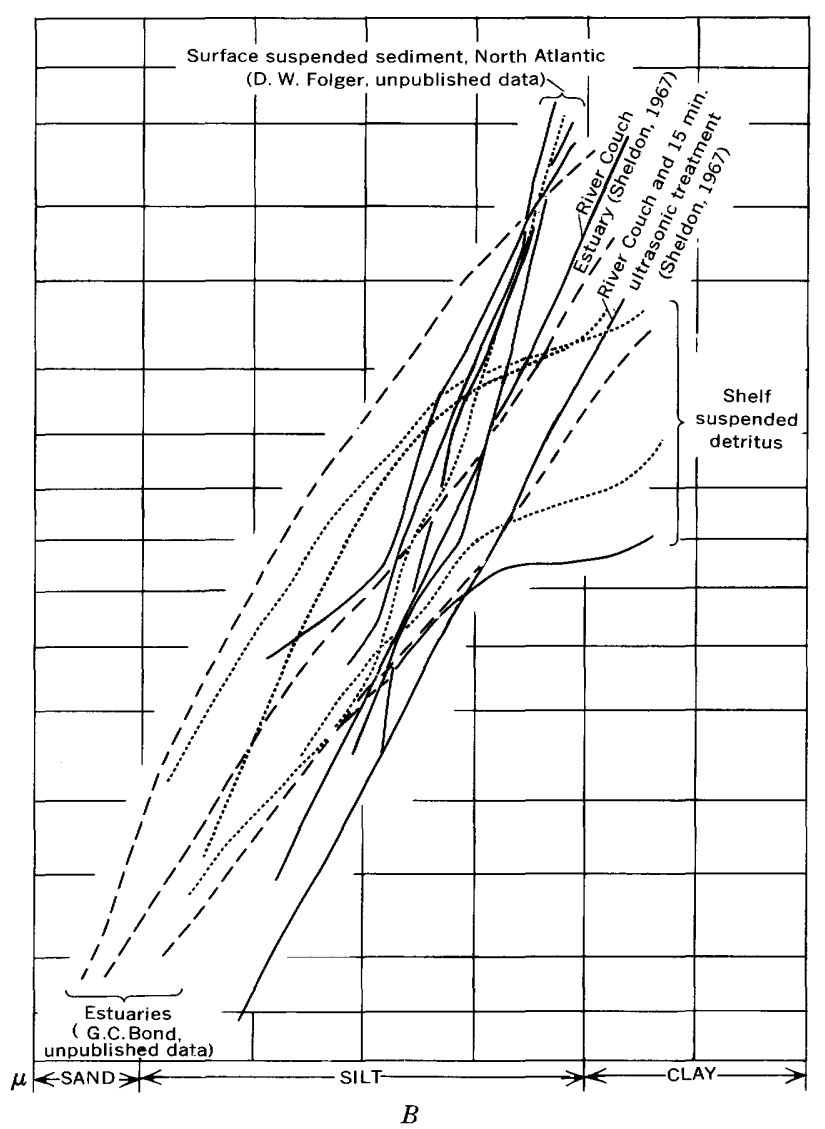

FIgURE 38.-Cumulative size analyses of fine-grained detritus. A, Abyssal plain lutites and one analysis of a contour-current silt (supplied by C. D. Hollister). $B$, Suspended sediment samples from surface waters. 
The role of turbidity currents as depositional agents appears to be a minor one on the upper continental rise. No obvious graded bedding or load casts, flame structures, and other types of sedimentary structures were obvious in the stiff silty clays examined from the rise. The field of points for continental rise sediments does not overlap fields shown on Passega's diagrams for turbidity-flow deposits; the coarsest value was in the fine to medium sand range, and the median fell in the very fine sand to coarse silt range. As shown on plate 2, sand is very scarce on the rise; hence the detritus needed for the coarse fraction of the turbidite is lacking. Curve shapes given by Visher (1969, fig. 20) again show little similarity to those of deposits on the continental rise, though they are taken from samples collected on the Hudson subsea fan. Some of the most clearly described turbidite layers are from cores taken on abyssal plains (Fruth, 1965; Heezen and Hollister, 1964; Schneider and others, 1967) and from rise deposits near or in channels on large subsea fans. Size data from the present study would tend to support the coring information shown by Schneider, Fox, Hollister, Needham, and Heezen (1967), - -specifically that the upper rise is not a dominant area of turbidity-flow deposition.

Gravity settling of the silt and clay probably is a dominant process. A comparison of size curves (fig. 19) with those analyses where settling from suspension is an important process (fig. 38), shows similarities, mainly with abyssal-plain sediments. Size analyses of hemipelagic grayish-brown homogeneous silty lutites (interbedded with the turbidity-current deposits) from the Sohm Plain, shows them (Fruth, 1965) to be (fig. 38A) similar to the silty clays of the upper continental rise and basins of the Gulf of Maine. They are skewed toward the coarse end when compared with silty clays, perhaps because some coarse debris from turbidite layers has gotten into the lutites as the result of reworking by benthic fauna. Fruth considers the pelagic lutites to be due to grain-by-grain accumulation of detritus. He notes the accumulation of nothing but this type of lutite on elevated rises that border the Sohm Abyssal Plain-areas that turbidity flows would be incapable of reaching. Besides a similar size curve shape and range, the moderately sorted silty clays do tend to be homogeneous like the lutites.

Analyses of suspended sediment (fig. 38B) show some similarity to those of the normally sorted silty clay of the lower slope and basins of the Gulf of Maine, but the suspended sediments are better sorted as a group than the bottom sediment. Closest affinities in curve shape are to suspended sediment samples taken over the shelf and to some of estuary detritus. Differences between analyses of the sediment and those of suspended detritus collected from the water column may result from techniques of analysis and from reworking of the debris after deposition. All the analyses shown in figure $38 B$ are based on optical counts of particles sedimented on filter paper; the bottom-sediment analyses are sized by pipetting. The difference in technique may be a partial explanation; some of the analyses lack any substantial clay fraction, and the pipette technique cannot create one. The fact that all the bottom-sediment samples in this program were ultrasonically disaggregated could have helped to create an abundance of fine detritus through cleaning off fine detritus adhering to larger grains. Sheldon (1967) has shown that disaggregation does cause a change, but that it is very small (fig. $38 B$ ); the ultrasonic treatment results mainly in a shift of the whole distribution toward finer sizes. The difference between the size distribution of actual suspended detritus and bottom sediment could also arise from the fact that sediment analyses size all detritusmineral grains and the biogenic debris-whereas the optical counts are of mineral grains alone. Postdepositional changes of the sediment, in part connected with (1) biogenic reworking, (2) the loss of the loose consolidation, and (3) breakdown of organic material, may also lead to more clay detritus.

Gravity settling as an important process is not incompatible with some transport by deep-sea currents. The main effect of the currents should be lateral transport of detritus. If they are effective, particles would tend to be dispersed far to the southwest as Hathaway's data shows (Hathaway, in press). Like currents on other parts of the continental margin, these probably change position, azimuth, and strength; hence some detritus would have an opportunity to settle out. The mixing of fine debris and the relatively coarse Foraminifera tests may account for the negative kurtosis, moderate sorting, and the presence of secondary modes. A slight coarsening ( $\mathrm{pl} .1$ ) of sediment types near the Hudson Canyon could be fallout of silt from turbidity currents; the coarest debris is restricted mainly to distributary channels that cross the rise on the Hudson subsea fan.

To summarize, (fig. 39) sedimentary patterns on the Atlantic continental margin off the Northeastern United States are the result of two main intervals of deposition, one during the Pleistocene (fig. 39A) when the drift, outwash, strandline deposits (outer 


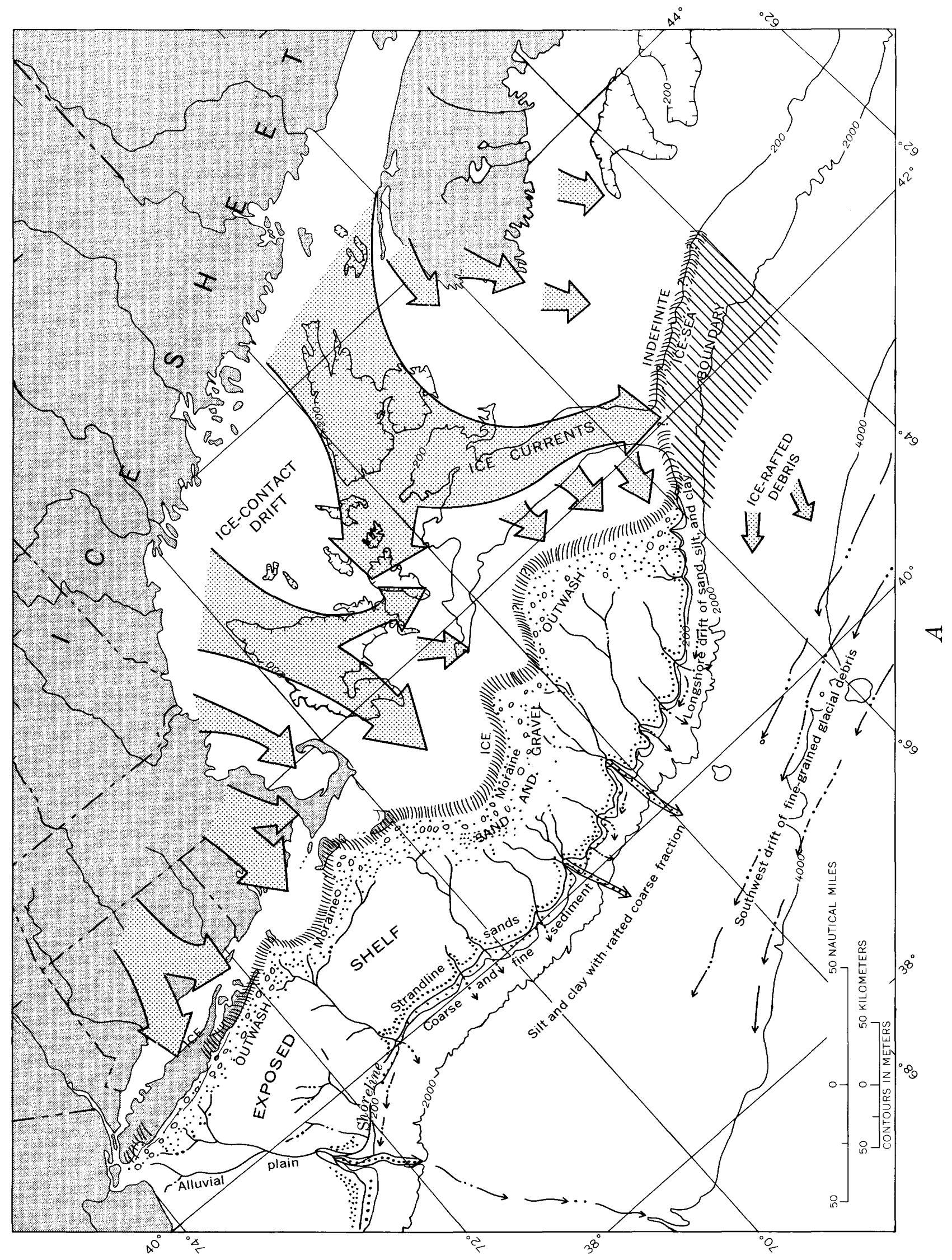




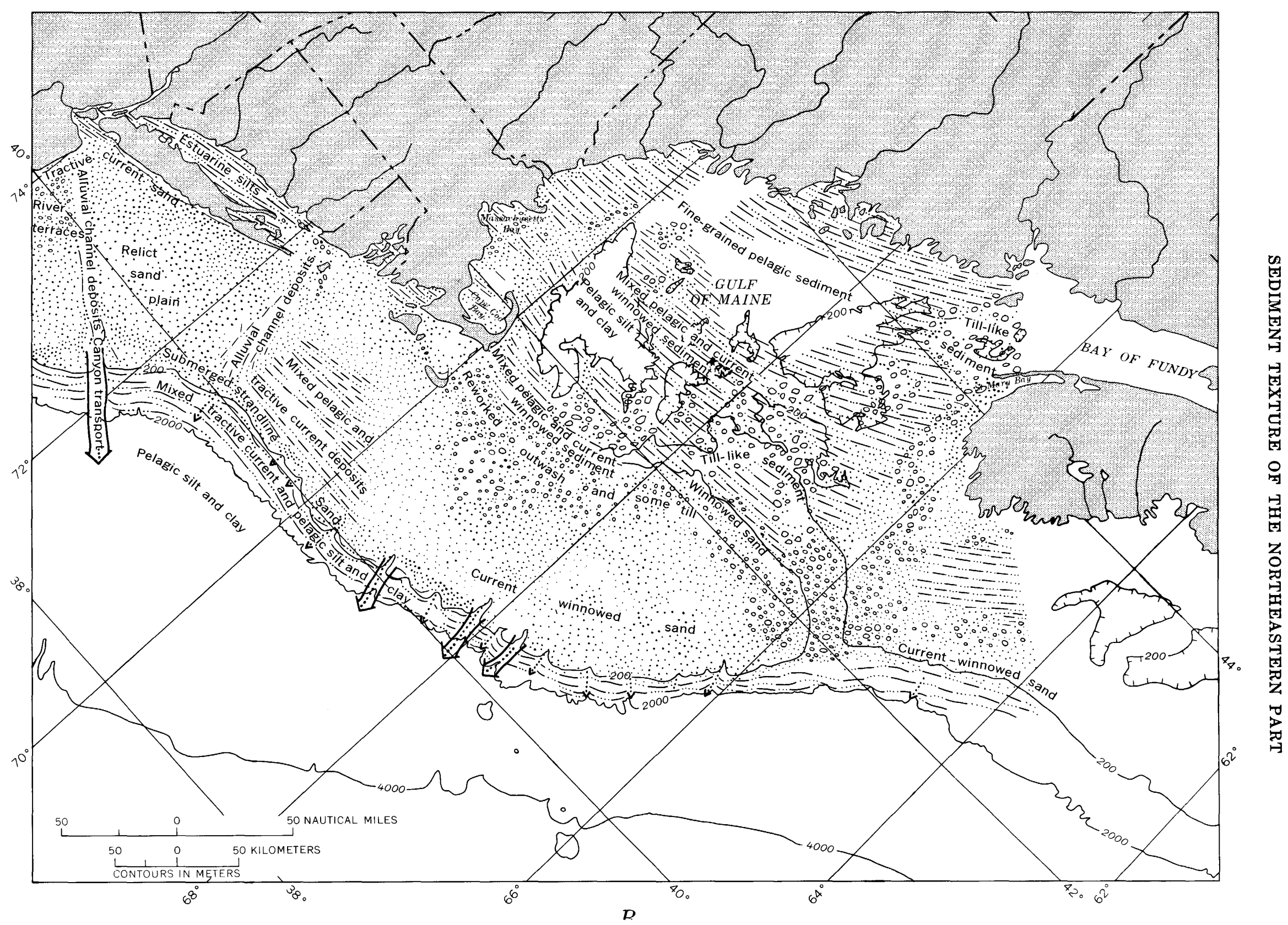

FIGURE 39.-Schematic maps of the northeastern continental margin showing texture and genesis of sediments during the Pleistocene ( $A$ ) and Holocene $(B)$. 
shelf), and alluvial-deltaic complexes across the shelf were formed, and the second during the Holocene rise in sea level when the glaciofluvial sediment was reworked by transgressive nearshore processes.

Glacial history is probably as complex offshore, as Kaye (1964) has shown it to be on land. Evidence from the sediment texture of multiple glaciation offshore is lacking, though the seismic profiles (fig. 34) do show several sets of buried channels on Georges Bank. The main processes of sediment dispersal during the Pleistocene, which are emphasized by this study, are deposition of ice-contact drift in the Gulf of Maine and Scotian Shelf, fluvial transport of outwash on Georges Bank and the shelf south of New England, littoral transport of sand near the shelf edge, and mass movement of sand and silt onto the slope and into canyons by slumping, sand falls, and downslope creep. Rafting by ice doubtless contributed a significant but unknown fraction.

The broad patterns of topography and sediment imprinted during Pleistocene glaciation have been incompletely modified since then. The Holocene transgression has caused erasure of melt-water channelways on Georges Bank, deposition of an apron for fine sand and silt around banks in the Gulf of Maine and the northern flank of Georges Bank, reworking of glacial deposits in shallow water, and deposition of strandline sands on the shelf. Sediment movement by tractive currents continues on to the present, perhaps emphasized by the slower rate of sea-level rise, to give rise to a barrier-sand ridge topography prevalent along some parts of the coast. The remainder of the shelf is likely reworked by similar tractive currents generated mainly by tides and storms, though the force and frequency of these agents have not been sufficient to modify relict topography and bury older sediment.

\section{GEOLOGIC CONCEPTS}

More than a decade ago, P. D. Krynine (1956, p. 63) warned in a paper entitled "Uniformitarianism is a dangerous doctrine" that extrapolation of the present conditions to the geologic past is endangered by misinterpreting "fossil glacial and pluvial phenomena as being recent." The presence of relict and modern sediment was emphasized by Shepard (1939, p. 228) and more recently by Emery (1968). One might conclude that a study of the present shelf has few if any concepts to offer for interpretation of the ancient rock record. One needs to be selective in looking at the area and to realize that (1) techniques of analysis are different from those used on geo- logical formations on land, and (2) the approach at sea is largely two-dimensional; hence study of sedimentary structures and lithologic units is severely limited. Notwithstanding these restrictions, some aspects of the study do have relevance to geologic concepts developed from the sedimentary rock record.

One of the oldest geologic models, that of continental glaciation, is reflected in sediment distribution offshore on the margin east of New England and the Maritime Provinces. It is similar to that noted on land (National Research Council, 1959; Pratt and Schlee, 1969) in that a broad area has been sculptured into a series of basins, knobs, swales, and ledges by ice. The area is veneered by ice-contact drift as much as several tens of meters thick. Basins are covered by later silty clay (pl. 5) just as in the lake basins of midwestern North America. The southern limit of glaciation is bordered by rounded quartzose gravelly outwash and moraines just as on land. The gravelly apron is restricted mainly to the northern part of Georges Bank and is connected to the southern edge of the bank by a series of channels later buried during the Holocene transgression. On the Scotian Shelf, the veneer of gravel extends in a patchy manner clear across the shelf, thus suggesting that the ice may have extended all the way to the shelf edge. A main outlet for glacial ice was through Northeast Channel and perhaps a secondary one through Great South Channel (fig. 39A). Postglacial marine transgression has altered the glacial pattern, but the main outline still persists. Alteration is mainly shown by reworked moraines and till on the shallow part of the Gulf of Maine and Georges Bank; the coarseness of the lag gravel testifies to its original mode of deposition.

These glacial deposits should show large lateral variation in grain size if preserved in the geologic record. Ill-sorted cobble conglomerates on rock benches would grade laterally to more complex associations of till and layered basin sediments plus associated englacial deposits (eskers, drumlins, crevasse fillings). Sorting should become better and the proportion of sand and gravel higher toward the periphery of glacial deposits and in the uppermost parts of the sequence (reworked detritus on banks). A concept of the vertical and lateral stratigraphic variability can be gained by looking at some of the continuous seismic profiles (fig. 34), though they are vertically exaggerated.

Away from the glacial front the sequence would be an anastomosing series of fluvial channel sands, probably coarser toward the maximum limit of glaciation; presumably these sands grade upward into 
the broadly crosslaminated units with shell debris and pebbly horizons toward the base-like presentday sand ridges and shoals in Georges and Nantucket Shoals. If preserved in the geologic record the marine and fluvial sands would grade laterally into shelf marine silty sand or sandy silt, like that south of Martha's Vineyard. In total aspect, the sequence would be marked by a basal unconformity across beveled formations of Tertiary and Cretaceous age and broadly channeled by fluvial and marine deposits which would intertongue or be interlayered in an anastomosing manner.

As noted by previous workers, the present shelf is a poor place to look for the transition toward finer sediment as distance from the shoreline becomes greater. As modal gradients showed (fig. 9A), the change exists, but it begins out near the shelf break and continues in a patchy fashion down the continental slope. This change most likely is inherited from the Pleistocene low stands of sea level during which fine and coarse detritus could be deposited directly on the slope and into submarine canyons. Size transitions exist away from dumped piles of glacial debris-as for example along the northern flank of Georges Bank (Wigley, 1961).

Deposition by tractive currents, ice, gravity settling, slumping, or combinations of two or more of these processes have been anticipated by interpreters of the geologic record. This study has emphasized that well-sorted quartzose shelf sands are formed in other places than the immediate area of the beach; seaward of the surf zone, sand is winnowed and sorted through the action of tidal currents and storm-generated currents. Key questions not answered here relate to the internal structure and geometry of these offshore sand bodies and the distinctive features that would allow one to identify them in the rock record.

Processes have been stressed in addition to the physiographic subdivisions of the continental margin, because they are basic to a description of any environment. Attempts to typify an environment (nearshore shelf, beach, estuary) by a set of textural parameters have been made with varying degrees of success (Friedman, 1967; Shepard and Young, 1961; Gees, 1965; Mason and Folk, 1958). A similar attempt is of doubtful value here until the other factors that influence the parameters (sediment provenance, biologic activity, and diagenetic changes) have been evaluated. The effects of sediment source on some statistical parameters have been pointed out. Much of the shelf sand is reworked by echinoderms and mollusks. What does this do to the size distribution? Later when the shelf sands are cemented, what hap- pens to the size distribution? All these factors have to be assessed before a meaningful set of criteria will emerge to distinguish different environments. Short of these criteria, half successes will result, and they will be limited to unconsolidated sediment and seemingly effective only for certain coastal areas; they will involve a bewildering miasma of statistical formulae meant to distinguish groups of data points. A noteworthy attempt to frame these parameters in terms of the hydraulic factors which influence size distribution has been made (Hand, 1967).

What the present study seeks to add to the picture of offshore sediment is that (1) basic populations of sand, gravel, and clay do exist; (2) the geologic significance of some kurtosis and skewness values may be in mixing of these basic populations; and (3) insight into processes acting on the continental shelf can result from examination of curve shape.

\section{ECONOMIC GEOLOGY}

Sand and gravel are the most important mineral commodities on the continental shelf to emerge from this investigation. Their distribution and origin have been dealt with from an economic viewpoint by Schlee (1968) and Schlee and Pratt (1970). Plates 1 and 2 show where the sand and gravel are abundant. Thickness figures on the sediment cover are sparse, but those that are available have been given by Schlee (1968).

Exploiters of relict glacial deposits will probably find them patchy in their areal distribution (as on land), variable in size, and having a matrix of finer sediment. Much of the sand and gravel is present as ledges, banks, and ridges in the Gulf of Maine. Toward the southeastern margin of maximum glacial advance, the same type of sediment is associated with submerged extensions of moraines southeast of Nantucket and between Long Island and Martha's Vineyard (Pratt and Schlee, 1969). The shelf south of New England is almost entirely covered with sand and some gravel. The gravel is adjacent to submerged relict alluvial channels, as, for example, off northern New Jersey, and relict strandline deposits, like those midway across the shelf south of Long Island. Size of gravel is more restricted in the nonglacial areas; it shows less compositional variability and is better rounded. Areal extent of sand and gravel deposits ranges from several hundred square kilometers for the relict terrace off New Jersey to a few square kilometers or less for some of the nearshore deposits. Additional deposits may be present over what is shown on the sediment maps. With a spacing so that each sample has to be representative of an area of $325 \mathrm{sq} \mathrm{km}$, some deposits have been 
overlooked. Hence, additional sampling both vertically and laterally are necessary for future exploration of the deposits.

Potential users will need to realize that some of the deposits are in active zones of sediment transport or that they provide an ecological niche for benthonic fauna important to the fishing industry. As noted in a previous section, the shore zone (out to $15-20 \mathrm{~m}$ depth) is one of periodic sand transport; hence, dredging from this area offers the potential hazard of tampering with the budget of sand in some sort of equilibrium with the current regime of the area.

Much of the sand and gravel is inhabited by a community of benthonic fauna living both in or on the sediment, such as pelecypods, gastropods, echinoderms, polychaete worms, and crustaceans. Directly or indirectly these animals affect commercial fishing interests. Some like lobsters inhabit crevices between cobbles and pebbles. Others like crustaceans, echinoderms, and mollusks that live in sandy sediment, provide the food for ground fish like haddock and cod (R. W. Wigley, oral commun., February 1969), particularly on Georges Bank. Hence, distribution of these fish is related to the sediment type. Some benthonic fauna, such as the sea anemone, which encrust gravel fragments in the Gulf of Maine, are several hundred years old (R. W. Wigley, oral commun., February 1969). Their destruction could break a link in the food cycle, one not easily reestablished after removal of the aggregate.

\section{CONCLUSIONS}

I wish to stress several aspects with respect to sediment texture on the continental margin.

1. Sedimentation on the continental shelf is in large measure the result of events during the Pleistocene and Holocene. A partial adjustment to modern conditions of bottom currents is suggested by the sorting and form of sand bodies in shoal-water areas, but lacking an influx of new sediment, most of the detritus on the shelf is the product of transport when sea level was lower than at present. Some of the sediment on the outer shelf is probably being reworked at present, but to such a limited extent that relict forms and textural patterns persist.

2. One of the earliest geologic models, that of continental glaciation, can be recognized in offshore areas by utilizing many of the same criteria that are used on land. These are the bathymetric-sedimentologic associations of a basin floored with silty clay, hummocky areas between basins covered by sandy silt or till-like sediment, and banks to the south bordered by reworked gravelly outwash. Though oversimplified, the model compares favorably with the pattern of englacial and fluvial deposits in the midwestern United States.

3. Attempts to typify any environment by a particular set of statistics is fruitless, mainly because several processes could have acted to produce a particular deposit, and these statistical parameters can be influenced by different sources of the sediments and by relict processes.

Scatter plots of the different statistical parameters versus one another show many of the same relationships noted by Folk and Ward (1957) ; in particular, a crudely sinusoidal relation between median size and standard deviation, and a U-shaped plot of skewness versus kurtosis. The deficiency of grainsize modes in the coarse-medium silt range and the granule range lends support to the idea that there are basic populations of grains in the clay-fine silt, sand, and gravel range. Mixing of these basic populations may be what we are observing in the statistical parameters other than median, much as Spencer (1963) has suggested.

4. In a gross manner, grouping of cumulative size curves shows five main types. Three of these types are log normal distributions with excellent, moderate, and poor sorting; they each appear to reflect the effects of transport and deposition by one main process, bottom currents, grain-by-grain settling, and ice. A fourth type, polymodal sand and gravel, is most likely the result of deposition as glacial outwash coupled with later reworking by tidal- and storm-generated bottom currents. A fifth type of skewed sandy silt, is probably due to mixing of sand and silt by two or more processes, gravity settling and tractive bottom currents.

5. A study of cores, drill-hole data, and continuous seismic profiles shows that the sediment type can change markedly with depth, in part because of reworking of relict deposits in shoal areas, or, as in the Gulf of Maine, because of a veneering of older englacial deposits by a silty clay layer $30-40 \mathrm{~m}$ or less thick. The continental slope shows both prograding and slumping of sediment; a few cores taken from the upper slope show no continuity from core to core of interbedded silty sand and silt.

\section{REFERENCES CITED}

Biederman, E. W., 1958, Shoreline sedimentation in New Jersey: University Park, Pa., Pennsylvania State Univ., unpub. Ph. D. dissert., 269 p.

Bumpus, D. F., 1965, Residual drift along the bottom on the continental shelf in the middle Atlantic bight area: Limnology and Oceanography, v. 10, supp., p. R50-R53.

Burbank, W. S., 1929, The petrology of the sediment of the Gulf of Maine and Bay of Fundy: U.S. Geol. Survey open-file report, $74 \mathrm{p}$. 
Chappell, John, 1967, Recognizing fossil strand lines from grain-size analysis: Jour. Sed. Petrology, v. 37, no. 1, p. $157-165$.

Charlesworth, L. J., 1968, Bay, inlet, and nearshore marine sedimentation: Beach Haven-Little Egg Inlet region, New Jersey: Ann Arbor, Mich., Michigan Univ., unpub. Ph. D. dissert., $260 \mathrm{p}$.

Curray, J. R., 1960a, Sediments and history of Holocene transgression, continental shelf, northwest Gulf of Mexico, in Shepard, F. P., Phleger, F. B., and van Andel, $\mathrm{Tj}$. H., eds., Recent sediments, northwest Gulf of Mexico: Tulsa, Okla., Am. Assoc. Petroleum Geologists, p. 221-266.

1960b, Tracing sediment masses by grain size modes: Internat. Geol. Cong., 21st, Copenhagen, 1960, pt. 23, p. 119-130.

1965, Late Quaternary history, continental shelves of the United States, in Wright, H. E., Jr., and Frey, D. G. eds., The Quaternary of the United States: Princeton, N. J., Princeton Univ. Press, p. 723-735.

Dietz, R. S., 1963, Wave-base, marine profile of equilibrium, and wave-built terraces-A critical appraisal: Geol. Soc. America Bull., v. 74, no. 8, p. 971-990.

- 1964, Wave-base marine profile of equilibrium, and wave-built terraces-Reply: Geol. Soc. America Bull., v. 75, p. 1275-1282.

Dill, R. F., 1964, Contemporary submarine erosion in Scripps Submarine Canyon: San Diego, Calif., California Univ., unpub. Ph. D. dissert., 269 p.

Doeglas, D. J., 1946, Interpretation of the results of mechanical analysis: Jour. Sed. Petrology, v. 16, p. 19-40.

Donahue, J. G., Allen, R. C., and Heezen, B. C., 1966, Sediment size distribution profile on the continental shelf off New Jersey: Sedimentology, v. 7, p. 155-159.

Draper, L., 1967, Wave activity at the sea bed around northwestern Europe: Marine Geology, v. 5, p. 133-140.

Duane, D. B., 1964, Significance of skewness in recent sediments, western Pamlico Sound, North Carolina: Jour. Sed. Petrology, v. 34 , no. 4, p. 864-874.

Emery, K. O., 1955, Grain size of marine beach gravels: Jour. Geology, v. 63 , no. 1, p. 39-49.

1966, The Atlantic Continental Shelf and Slope of the United States-Geologic background: U.S. Geol. Survey Prof. Paper 529-A, 23 p.

1968, Relict sediments on continental shelves of world: Am. Assoc. Petroleum Geologists Bull., v. 52, no. 3 , p. $445-464$.

Emery, K. O., and Garrison, L. E., 1967, Sea level 7,000 to 20,000 years ago: Science, v. 157 , no. 3789 , p. $684-687$.

Emery, K. O., Merrill, A. S., and Trumbull, J. V. A., 1965, Geology and biology of the sea floor as deduced from simultaneous photographs and samples: Limnology and Oceanography, v. 10 , no. 1 , p. 1-21.

Emery, K. O., and Ross, D. A., 1968, Topography and sediments of a small area of the continental slope south of Martha's Vineyard: Deep-Sea Research, v. 15, no. 4, p. $415-422$.

Emery, K. O., and Uchupi, Elazar, 1965, Structure of Georges Bank: Marine Geology, v. 3, no. 5, p. 349-358.

Emery, K. O., Wigley, R. L., Bartlett, A. S., Rubin, Meyer, and Barghoorn, E. S., 1967, Freshwater peat on the continental shelf: Science, v. 158, p. 1301-1307.

Emery, K. O., Wigley, R. L., and Rubin, Meyer, 1965, A submerged peat deposit off the Atlantic Coast of the
United States: Limnology and Oceanography, v. 10, Supp., p. R97-R102.

Ewing, John, LePichon, Xavier, and Ewing, Maurice, 1963, Upper stratification of Hudson apron region: Jour. Geophys. Research, v. 68, no. 23, p. 6303-6316.

Flint, R. F., 1957, Glacial and Pleistocene geology: New York, John Wiley \& Sons, 553 p.

Fofonoff, N. P., 1968, Current measurements from moored buoys, 1959-1965: Woods Hole Oceanog. Inst. Ref. no. $68-30,[24] \mathrm{p}$.

Folk, R. L., 1962, Of skewnesses and sands [discussion of paper by F. P. Shepard and R. Young, 1961]: Jour. Sed. Petrology, v. 32, no. 1, p. 145-146.

- 1964, Petrology of sedimentary rocks: Austin, Tex., Hemphill's, $154 \mathrm{p}$.

- 1966, A review of grain-size parameters: Sedimentology, v. 6, p. 73-93.

Folk, R. L., and Ward, W. C., 1957, Brazos River bar-a study in the significance of grain size parameters: Jour. Sed. Petrology, v. 27, no. 1, p. 3-26.

Friedman, G. M., 1961, Distinction between dune, beach, and river sands from their textural characteristics: Jour. Sed. Petrology, v. 31, no. 4, p. 514-529.

1967, Dynamic processes and statistical parameters compared for size frequency distribution of beach and river sands: Jour. Sed. Petrology, v. 37, no. 2, p. 327354.

Fruth, L. S., 1965, The 1929 Grand Banks turbidite and sediments of the Sohm Abyssal Plain: New York, Columbia Univ., M. S. thesis.

Fuller, A. O., 1961, Size distribution characteristics of shallow marine sands from the Cape of Good Hope, South Africa: Jour. Sed. Petrology, v. 31, no. 2, p. 256261.

- 1962, Systemic fractionation of sand in the shallow marine and beach environment off the South African coast: Jour. Sed. Petrology, v. 32, no. 3, p. 602-606.

Garrison, L. E., and McMaster, R. L., 1966, Sediments and geomorphology of the continental shelf off southern New England: Marine Geology, v. 4, no. 4, p. 273-289.

Gees, R. A., 1965, Moment measures in relation to the depositional environments of sands: Eclogae Geol. Helvetiae, v. 58 , no. $1,209-213$.

Gibson, T. G., 1965, Eocene and Miocene rocks off the northeastern coast of the United States: Deep-Sea Research, v. 12 , p. $975-981$.

Griscom, Clement, 1968, An analysis of subsurface currents and temperatures at a site on the continental shelf of the northeast United States: General Dynamics Rept. U413-68-109, $60 \mathrm{p}$.

Hand, B. M., 1967, Differentiation of beach and dune sands using settling velocities of light and heavy minerals: Jour. Sed. Petrology, v. 37, no. 2, p. 514-520.

Hartshorn, J. H., 1958, Flowtill in southeastern Massachusetts: Geol. Soc. America Bull., v. 69, no. 4, p. 477-482. 1967, Geology of the Taunton quadrangle, Bristol and Plymouth Counties, Massachusetts: U.S. Geol. Survey Bull. 1163-D, $67 \mathrm{p}$.

Hathaway, J. C., ed., 1966, Data file, Continental Margin Program, Atlantic Coast of the United States; v. 1, Sample collection data: Woods Hole Oceanog. Inst. Ref. no. $66-8,184 \mathrm{p}$. 
Hathaway, J. C., 1972, Regional clay mineral facies in the estuaries and continental margin of the United States East Coast: Geol. Soc. America Spec. Paper. (In press.)

Hathaway, J. C., Schlee, J. S., Trumbull, J. V. A., and Hülsemann, Jobst, 1965, Sediments of the Gulf of Maine [abs.]: Am. Assoc. Petroleum Geologists Bull., v. 49, no. 3 , p. 343-344.

Hayes, M. O., 1966, Sedimentation on a semiarid, wavedominated coast (South Texas) with emphasis on hurricane effects [abs.]: Dissert. Abs., v. 26, p. 7258.

Heezen, B. C., and Hollister, Charles, 1964, Deep-sea current evidence from abyssal sediments: Marine Geology, v. 1, no. 2, p. 141-174.

Heezen, B. C., Tharp, Marie, and Ewing, Maurice, 1959, The floors of the oceans; I, The North Atlantic: Geol. Soc. America Spec. Paper 65, 122 p.

Horberg, C. L., and Potter, P. E., 1965, Stratigraphic and sedimentologic aspects of the Lemont drift of northeastern Illinois: Illinois State Geol. Survey Rept. Inv. $185,23 \mathrm{p}$.

Hoskins, Hartley, 1967, Seismic reflection observations on the Atlantic Continental Shelf, Slope, and Rise southeast of New England: Jour. Geology, v. 75, no. 5, p. $598-611$.

Houbolt, J. J. H. C., 1968, Recent sediments in the southern bight of the North Sea: Geologie en Mijnbouw, v. 47, p. 245-273.

Hough, J. L., 1942, Sediments of Cape Cod Bay, Massachusetts: Jour. Sed. Petrology, v. 12, no. 1, p. 10-30.

Hülsemann, Jobst, 1967, The continental margin off the Atlantic coast of the United States-Carbonate in sediments, Nova Scotia to Hudson Canyon: Sedimentology, v. 8 , no. 2 , p. 121-145.

Hurley, R. J., 1964, Bathymetric data from the search for USS "Thresher": Internat. Hydrog. Rev., v. 41, p. 43-52.

Jordan, R. R., 1968, Suspended and bottom sediments in the Delaware Estuary [abs.]: Geol. Soc. America, Northeastern Sec., Ann. Mtg., 1968, Program p. 37-38.

Kaye, C. A., 1964, Outline of Pleistocene geology of Martha's Vineyard, Massachusetts: U.S. Geol. Survey Prof. Paper 501-C, p. C134-C139.

King, L. H., 1965, Use of a conventional echo-sounder and textural analyses in delineating sedimentary faciesScotian Shelf: Canadian Jour. Earth Sci., v. 4, p. 691708.

- 1967, On sediments and stratigraphy of the Scotian Shelf, in Neale, E. R. W., ed., Collected papers on the geology of the Atlantic region: Geol. Assoc. Canada Spec. Pub, 4, p. 71-92.

1969, Submarine end moraines and associated deposits on the Scotian Shelf: Geol. Soc. America Bull., v. 80, no. 1 , p. $83-96$.

Klovan, J. E., 1966, The use of factor analysis in determining depositional environments from grain-size distributions: Jour. Sed. Petrology, v. 36 , no. 1, p. 115-125.

Knott, S. T., and Hoskins, Hartley, 1968, Evidence of Pleistocene events in the structure of the continental shelf off the northeastern United States: Marine Geology, v. 6, no. 1, p. 5-43.

Koldewijn, B. W., 1958, Sediments of the Paria-Trinidad shelf; reports of the Orinoco Shelf Expedition, v. 3, The Hague, Mouton \& Co., 109 p.

Krause, D. C., Chramiec, M. A., Walsh, G. M., and Wisotsky, Serge, 1966, Seismic profile showing Cenozoic develop- ment of the New England continental margin: Jour. Geophys. Research, v. 71 , no. 18, p. 4327-4332.

Krumbein, W. C., 1933 Textural and lithological variations in glacial till: Jour. Geology, v. 41, no. 4, p. 382-408.

Krumbein, W. C., and Aberdeen, E. J., 1937, The sediments of Barataria Bay [Louisiana]: Jour. Sed. Petrology, v. 7, no. 1, p. 3-17.

Krumbein, W. C., and Pettijohn, F. J., 1938, Manual of sedimentary petrography: New York, Appleton-CenturyCrofts, $549 \mathrm{p}$.

Krynine, P. D., 1956, Uniformitarianism is a dangerous doctrine [abs.]: Jour. Paleontology, v. 30, no. 4, p. 1003-1004.

Lauzier, L. M., 1967, Bottom residual drift on the continental shelf area of the Canadian Atlantic Coast: Canada Fisheries Research Board Jour., v. 24, p. 18451859.

Linell, K. A., and Shea, H. F., 1960, Strength and deformation characteristics of various glacial tills in New England, in Soc. Civil Engineers Research Conference on shear strength of cohesive soils, University of Colorado, 1960: New York, Am. Soc. Civil Engineers, p. 275-314.

Lowrie, Allen, Jr., and Heezen, B. C., 1967, Knoll and sediment drift near Hudson Canyon: Science, v. 157, no. 3796, p. 1552-1553.

Mason, C. C., and Folk, R. L., 1958, Differentiation of beach, dune, and aeolian flat environments by size analysis, Mustang Island, Texas: Jour. Sed. Petrology, v. 28, no. 2, p. 211-226.

McMaster, R. L., 1954, Petrography and genesis of the New Jersey beach sands: New Jersey Dept. Conserv., Geol. Ser. Bull. 63, 239 p.

1960, Sediments of Narragansett Bay system and Rhode Island Sound, Rhode Island: Jour. Sed. Petrology, v. 30 , no. 2 , p. $249-274$.

1962, Petrography and genesis of recent sediments in Narragansett Bay and Rhode Island Sound, Rhode Island: Jour. Sed. Petrology, v. 32, no. 3, p. 484-501.

McMaster, R. L., and Garrison, L. E., 1966, Mineralogy and origin of southern New England shelf sediments: Jour. Sed. Petrology, v. 36, no. 4, p. 1131-1142.

— 1967, A submerged Holocene shoreline near Block Island, Rhode Island: Jour. Geology, v. 75 , no. 3 , p. $335-340$.

McMaster, R. L., Lachance, T. P., and Garrison, L. E., 1968, Seismic-reflection studies in Block Island and. Rhode Island Sounds: Am. Assoc. Petroleum Geologists Bull., v. 52 , no. 3 , p. $465-474$.

Merrill, A. S., Emery, K. O., and Rubin, Meyer, 1965, Ancient oyster shells on the Atlantic Continental Shelf: Science, v. 147 , no. 3656 , p. 398-400.

Moiola, R. J., and Weiser, D., 1968, Textural parametersAn evaluation: Jour. Sed. Petrology, v. 38, no. 1, 45-53.

Moody, D. W., 1964, Coastal morphology and processes in relation to the development of submarine sand ridges off Bethany Beach, Delaware: Baltimore, Md., Johns Hopkins Univ., unpub. Ph. D. dissert., $165 \mathrm{p}$.

Moore, D. G., and Curray, J. R., 1964, Wave-base, marine profile of equilibrium, and wave-built terraces-Discussion of a paper by R. S. Dietz (1963): Geol. Soc. America Bull., v. 75, no. 12, p. 1267-1274.

Moss, A. J., 1962, The physical nature of common sandy and pebbly deposits: Am. Jour. Sci., v. 260, p. 337-373. 
1963, The physical nature of common sandy and pebbly deposits, pt. 2: Am. Jour. Sci., v. 261, p. 297343.

Munsell Color Company, 1929-1960, Munsell book of color: Baltimore, Md. [unnumbered pages]. Also available in pocket edition.

Murray, H. W., 1947, Topography of the Gulf of Maine, field season of 1940: Geol. Soc. American Bull., v. 58, no. 2 , p. $153-196$.

National Research Council, Division of Earth Sciences, 1959, Glacial map of the United States east of the Rocky Mountains: New York, Geol. Soc. America, 2 sheets, scale $1: 1,750,000$.

Northrop, John, and Heezen, B. C., 1951, An outcrop of Eocene sediment on the continental slope: Jour. Geology, v. 59 , no. 4, p. 396-399.

Oberkommando der Kriegsmarine, 1943, Uboot handbuch der Ostküste der Vereinigen Staaten von Nordamerika, Nördlicher Teil (atlas) : Berlin, 124 charts.

Off, Theodore, 1963, Rhythmic linear sand bodies caused by tidal currents: Am. Assoc. Petroleum Geologists Bull., v. 47 , no. 2 , p. $324-341$.

Ostericher, Charles, 1965, Bottom and subbottom investigation of Penobscot Bay, Maine, 1959: U.S. Naval Oceanog. Office, Tech. Rept. 173, 177 p.

Owen, D. M., Emery, K. O., and Hoadley, L. D., 1967, Effects of tidal currents on the sea floor shown by underwater time-lapse photography, in Hersey, J. B., Deep-sea photography: Baltimore, Md., Johns Hopkins Press, p. 159-166.

Passega, Renata, 1957, Texture as characteristic of clastic deposition: Am. Assoc. Petroleum Geologists, v. 41, no. 9 , p. $1952-1984$.

_ 1964, Grain size representation by CM patterns as a geologic tool: Jour. Sed. Petrology, v. 34, no. 4, p. 830-847.

Pettijohn, F. J., 1957, Sedimentary rocks: 2d ed., New York, Harper \& Bros., 718 p.

Plumley, W. J., 1948, Black Hills terrace gravels: a study in sediment transport: Jour. Geology, v. 56, no. 6, p. $526-577$.

Potter, P. E., 1955, The petrology and origin of the Lafayette Gravel-Part I, Mineralogy and petrology: Jour. Geology, v. 63, no. 1, p. 1-38.

Pourtales, L. F., de, 1872, The Gulf Stream-Characteristics of the Atlantic sea-bottom off the coast of the United States: U.S. Coast and Geodetic Survey, Rept. Superintendent 1869, app. 11, p. 220-225.

Pratt, R. M., 1967, The seaward extension of submarine canyons off the northeast coast of the United States: Deep-Sea Research, v. 14, no. 4, p. 409-420.

Pratt, R. M, and Schlee, John, 1969, Glaciation on the continental margin off New England: Geol. Soc. America Bull., v. 80, no. 11, p. 2335-2341.

Rad, Ulrich, von, 1968, Comparison of sedimentation in the Bavarian flysch (Cretaceous) and Recent San Diego trough (California): Jour. Sed. Petrology, v. 38, no. 4, p. 1120-1154.

Redfield, A. C., 1967, Postglacial change in sea level in the western North Atlantic Ocean: Science, v. 157, no. 3789, p. 687-692.

Ross, D. A., 1967, Heavy-mineral assemblages in the nearshore surface sediments of the Gulf of Maine: U.S. Geol. Survey Prof. Paper 575-C, p. C77-C80.
1970, Atlantic Continental Shelf and Slope of the United States-heavy minerals, continental margin, from southern Nova Scotia to northern New Jersey: U.S. Geol. Survey Prof. Paper 529-G, 40 p.

Schafer, J. P., and Hartshorn, J. H., 1965, The Quaternary of New England, in Wright, H. E., Jr., and Frey, D. G., The Quaternary of the United States: Princeton, N. J., Princeton Univ. Press, p. 113-128.

Schlee, John, 1957, Upland gravels of southern Maryland: Geol. Soc. America Bull., v. 68, no. 10, p. 1371-1410.

- 1964, New Jersey offshore gravel deposit: Pit and Quarry, v. 57, no. 6, 80-81, 95.

1966, A modified Woods Hole Rapid Sediment Analyzer: Jour. Sed. Petrology, v. 36, no. 2, 403-413.

1968, Sand and gravel on the continental shelf off the northeastern United States: U.S. Geol. Survey Circ. $602,9 \mathrm{p}$.

Schlee, John, and Pratt, R. M., 1970, Atlantic Continental Shelf and Slope of the United States-gravels of the northeastern part: U.S. Geol. Survey Prof. Paper 529$\mathrm{H}, 39 \mathrm{p}$.

Schlee, John, Uchupi, Elazar, and Trumbull, J. V. A., 1964, Statistical parameters of Cape Cod beach and eolian sands: U.S. Geol. Survey Prof. Paper 501-D, p. D118D122.

Schlee, John, and Webster, Jacqueline, 1967, A computer program for grain-size data: Sedimentology, v. 8, p. $45-53$.

Schneider, E. D., Fox, P. J., Hollister, C. D., Needham, H. D., and Heezen, B. C, 1967, Further evidence of contour currents in the western North Atlantic: Earth and Planetary Sci. Letters, v. 2, p. 351-359.

Sheldon, R. W., 1967, Sedimentation in the estuary of the River Couch, Essex, England: Limnology and Oceanography, v. 13, no. 1 , p. $72-84$.

Shepard, F. P., 1932, Sediments of the continental shelves: Geol. Soc. America Bull., v. 43, no. 4, p. 1017-1040. 1939, Continental shelf sediments, in Trask, P. D., ed., Recent marine sediments a symposium: Tulsa, Okla., Am. Assoc. Petroleum Geologists, p. 219-229.

1954, Nomenclature based on sand-silt-clay ratios: Jour. Sed. Petrology, v. 24, p. 151-158.

Shepard, F. P., and Cohee, G. V., 1936, Continental shelf sediments off the Mid-Atlantic States: Geol. Soc. America Bull., v. 47, no. 3, p. 441-457.

Shepard, F. P., Trefethen, J. M., and Cohee, G. V., 1934, Origin of Georges Bank: Geol. Soc. America Bull., v. 45 , no. 2, p. 281-302.

Shepard, F. P., and Young, Ruth, 1961, Distinguishing between beach and dune sands: Jour. Sed. Petrology, v. 31, no. ؟, p. 196-214.

Smith, J. D., 1969, Geomorphology of a sand ridge: Jour. Geology, v. 77, no. 1, 39-55.

Spencer, D. W., 1963, The interpretation of grain size distribution curves of clastic sediments: Jour. Sed. Petrology, v. 33, no. 1, p. 180-190.

Stanley, D. J., 1969, Atlantic Continental Shelf and Slope of the United States-Color of marine sediments: U.S. Geol. Survey Prof. Paper 529-D, 15 p.

Stanley, D. J., and Kelling, Gilbert, 1968, Sedimentation patterns in the Wilmington submarine canyon area, in Ocean Sciences and engineering of the Atlantic Shelf: Marine Technology Soc., Fourth Ann. MTS Conf. and Exhibit, 1968, Trans., p. 127-142. 
Stetson, H. C., 1938, The sediments of the continental shelf off the eastern coast of the United States: Massachusetts Inst. Technology and Woods Hole Oceanog. Inst. Papers in Physical Oceanography and Meteorology, v. 5, no. 4, 48 p.

Stewart, H. B., Jr., and Jordan, G. F., 1964, Underwater sand ridges on Georges Shoal, in Miller, R. L., ed., Papers in marine geology, F. P. Shepard commemorative volume: New York, Macmillan Co., p. 102-114.

Sundborg, Ake, 1956, The river Klarälven; a study of fluvial processes: Geog. Annaler, Arg. 38, h. 2-3, p. 125-316.

Swift, D. J. P., 1969, Mesozoic versus modern sedimentation of the Carolina Coast and the problem of the graded shelf [abs.]: Geol. Soc. America Spec. Paper 121, p. 468.

Torphy, S. R., and Zeigler, J. M., 1957, Submarine topography of Eastern Channel, Gulf of Maine: Jour. Geology, v. 65 , no. 4 , p. $433-441$.

Trumbull, J. V. A., and McCamis, M. J., 1967, Geological exploration in an East Coast submarine canyon from a research submersible: Science, v. 158 , no. 3799 , p. 370 372 .

Uchupi, Elazar, 1965a, Map showing relation of land and submarine topography, Nova Scotia to Florida: U.S. Geol. Survey Misc. Geol. Inv. Map I-451, 3 sheets, scale $1: 1,000,000$.

1965b, Basins of the Gulf of Maine: U.S. Geol. Survey Prof. Paper 525-D, p. D175-D177.

1966a, Topography and structure of Northeast Channel, Gulf of Maine: Am. Assoc. Petroleum Geologists Bull., v. 50, no. 1, p. 165-167.

1966b, Structural framework of the Gulf of Maine: Jour. Geophys. Research, v. 71, no. 12, p. 3013-3028.

1966c, Topography and structure of Cashes Ledge, Gulf of Maine: Maritime Sediments, v. 2, p. 112-120.

- 1967, Slumping on the continental margin southeast of Long Island, New York: Deep-Sea Research, v. 14, no. 5 , p. $635-638$.

1968, The Atlantic Continental Shelf and Slope of the United States-Physiography: U.S. Geol. Survey Prof. Paper 529-C, 30 p.

1970, Atlantic Continental Shelf and Slope of the United States-Shallow structure: U.S. Geol. Survey Prof. Paper 529-I, 44 p.

Uchupi, Elazar, and Emery, K. O., 1967, Structure of continental margin off Atlantic coast of United States: Am. Assoc. Petroleum Geologists Bull., v. 51, no. 2, p. 223234.

Udden, J. A, 1914, Mechanical composition of clastic sediments: Geol. Soc. America Bull., v. 25, p. 655-744.
U.S. Coast and Geodetic Survey and U.S. Bureau of Commercial Fisheries, 1967, [Bathymetric maps of the Atlantic Continental Shelf and Slope from Delaware to outer Cape Cod]: U.S. Coast and Geodetic Survey C \& GS $0708 \mathrm{~N}-51$ through 53, 0807-51, through 57, $0808 \mathrm{~N}-51$ through 55,15 sheets, scale $1: 125,000$.

van Andel, Tj. H., 1964, Recent marine sediments of Gulf of California, in van Andel, Tj. H., and Shor, G. G., Jr., eds., Marine geology of the Gulf of California-A symposium: Am. Assoc. Petroleum Geologists Mem. 3, p. 216-310.

van Andel, Tj. H., and Postma, Hendrik, 1954, Recent sediments of the Gulf of Paria; reports of the Orinoco Shelf Expedition, v. 1: Koninkl. Nederlandse Akad. Wetensch. Verh., ser. 1, pt. 20, no. 5, 238 p.

Veatch, A. C., and Smith, P. A., 1939, Atlantic submarine valleys of the United States and the Congo submarine valley: Geol. Soc. America Spec. Paper 7, $101 \mathrm{p}$.

Visher, G. S., 1965, Fluvial processes interpreted from ancient and recent fluvial deposits, in Middleton, G. V., ed., Primary sedimentary structures and their hydrodynamic interpretation-a symposium: Soc. Econ. Paleontologists and Mineralogists Spec. Pub. 12, p. 116132.

- 1967, Grain-size distributions and depositional processes: 7th Internat. Sedimentological Cong., Reading, England, 1967, 7 p. preprint.

1969, Grain-size distributions and depositional processes: Jour. Sed. Petrology, v. 39, no. 3, p. 1074-1106.

Volkmann, G., 1962, Deep current observations in the western North Atlantic: Deep-Sea Research, v. 9, p. 493500 .

Wentworth, C. K., 1932, The mechanical composition of sediments in graphic form: Iowa Univ. Studies Nat. History, v. 14, no. 3,127 p.

Wigley, R. L., 1961, Bottom sediments of Georges Bank: Jour. Sed. Petrology, v. 31, no. 2, p. 165-188.

Woods Hole Oceanographic Institution, 1964, Summary of investigations conducted in 1963, Woods Hole Oceanographic Institution, Woods Hole, Mass.: Woods Hole Oceanog. Inst. Ref. no. $64-12,220$ p.

- 1965, Summary of investigations conducted in 1964, Woods Hole Oceanographic Institution, Woods Hole, Mass.: Woods Hole Oceanog. Inst. Ref. no. 65-13, 250 p.

Zeigler, J. M., and Ronne, F. C., 1957, Time-lapse photography_an aid to studies of the shoreline: U.S. Office Naval Research, Research Reviews, p. 1-6.

Zeigler, J. M., Tuttle, S. D., Giese, G. S. and Tasha, H. J., 1964, Residence time of sand composing the beaches and bars of outer Cape Cod, in Coastal Engineering, 9th Conf., Lisbon, Portugal, 1964, Proc.: New York, Am. Soc. Civil Engineering, p. 403-416. 